UNIV. OF TORONTO LIBRAFY 






Digitized by the Internet Archive in 2008 with funding from Microsoft Corporation 
Aberdeen University

Studies : No. $3^{8}$

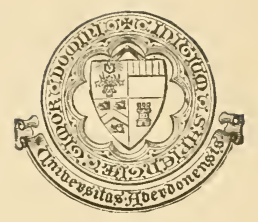

Alcyonarians

and

Hydroids 


\section{University of Aberdeen.}

\section{COMMITTEE ON PUBLICATIONS.}

Convener : Professor James W. H. TraIL, F.R.S., Curator of the Library.

$$
\text { UNIVERSITY STUDIES. }
$$

General Editor: P. J. ANderson, LL.B., Librarian to the University.

1900. No. 1.-Roll of Alumni in Arts of King's College, 1596-I850. P. J. Andersoo.

n. No. 2-Reconts of Old Aberdeen, Ir57-1S91. A. M. Muoro, F.S.A. Scot. Vol. I.

" No. 3+-Place Names of West Aberdeenshire. James Macdonald, F.S.A. Scot.

19or. No. 4.-Family of Bumett of Leys. George Burnett, LL.D, Lyon King of Arms

No. 5.-Records of Inercauld, 1547*t828. Rev. J. G. Michie, M.A.

1902. No. 6,-Retorial Addresses in the Universities of Aberdeen, $1835-1900$. P. J. Anderso1.

No. 7.-Albemarle Papers, 1746-48. Professor C. S. Terry, M.A.

1903. No, 8.-House of Gordon. J. M. Bulloch, M.A. Vol. 1.

No. 9.-Records of Elgin. William Cramond, LL.D. Vol. I.

1904. No. 10,-A trogadro and Dalton. A. N. Meldrum, D.Sc.

"No, 11,-Records of the Sheriff Court of Aberdeenshire. David Littlejoho, LL.D. Vel.

No, 12.-Proceedings of the Aratomical and Anthropological Sociely, 1902-04.

1905. No. i3,-Report on Alcyonaria. Professor J. Arthur Thomson, M.A., and others.

. No. 14.-Researches in Organic Chemistry. Prol. F. R. Japp, F.R.S., aod others.

No. 15.-Meminisse Juvat: with Appendix of Alakcia. Alexaoder Shewan, M.A.

No. 16.-Blackhalls of that Ilk and Barra. Alexander Morison, M.D.

1906. No. 17.-Records of the Scots Colleges. Vol. 1. P. J. Andersoo.

. No. 18.-Roll of the Graduates, 2860-1900. Colonel William Johnston, C.B., LL.D.

" No. 19-Studies in the History of the Unitersity:. P. J. Aoderson and others.

No. 20-Studies in the History and Art of the Eastern Provinces of the Roman Emp:ne. Professor Sir W. M. Ramsay, D.C.L., and pupils.

No. 21.-Studies in Pathology. William Bulloch, Mi.D., and others.

No. 22.-Proceedings of the Anatomical and Anthropological Society, 1904-06.

No. 23.- -Subject Catalogues of the Science Library and the Law Library. P. J. Andersoo.

No. 24-Records of the Sheriff Court of Aberdecnshire. David Littlejohn, LL.D. Vol. II

1907. No. 25.-Studics on Alcyonarians and A ntipatharians. Prot. Thomson, M.A., and others.

No. 26.-Surgical Instruments in Greek ant Roman Times. J. S. Milne, M.A., M.D.

. No. 27,-Records of the Sheriff Court of Aberdeenshire. David Littlejohn, LL.D. Vol. III.

No. 28.-Flosculi Graeci Boreales. Ser. II. Professor John Harrower, M.A.

n No. 29.-Record of the Quatercentenary, igo6. P. J. Andersoo.

". No. 30.-House of Gordon. J. M. Bulloch, M.A. Vol. 11.

rgos. No. 3r.-Miscellany of the Nicw Spaldng Club. Vol. II.

. No. 32,-Religious Teachers of Greece. James Adam, Litt.D. (Gifford Lectures, 1904-06.)

" No. 33.-Science and Philosophy of the Organism. Hans Driesch, Ph.D. (Giff. Lect., 1907.)

" No. 3+-Procedings of the A natomical and Anthropological Society, tgo6-oS.

"No. 35--Records of Elgin. Vol. 11. Rev. S. Ree, B.D.

" No. 36.-Pigmentation Survey of School Children. J. F. Tocher, B.Sc.

19og. No. 37.-Scicnce and Philosophy of Organism. Hans Driesch, Ph.D. Vol. II. (Giff. Lect., Igo9.)

.. No. 38.-Studies on Alcyonarians and Hydroids. Prol. Thomson, M.A., and others. 


\title{
Studies
}

\section{on \\ Alcyonarians and Hydroids}

(Third Series)

\author{
By \\ J. Arthur Thomson, M.A. \\ Professor of Natural History \\ James Ritchie, M.A., B.Sc. \\ Fullerton Scholar \\ James M. McQueen, M.A., B.Sc.
}

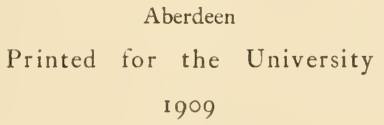





\section{CONTENTS.}

The Hrdroids of the Scottish National Antartic Expedition. By Mr. Ritchie - $1-27$

Three Plates - $\quad$ - $\quad$ - $\quad$ - $\quad$ - $\quad$ - $\quad$ - 27

Note on Prinnoa reseda from the Faroe Channel and on its Embryos. By Professor

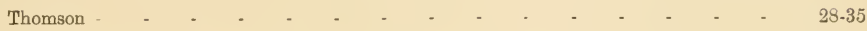

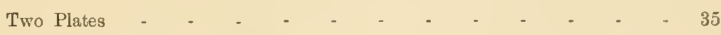

On the Occurrence of a supposed Australasian Hydroid (Sertularia elongata) in the

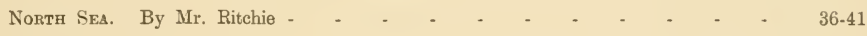

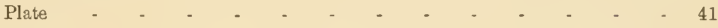

On Collections of the Cape Verde Islands Marine Fauna made by CyriL Crossland,

M.A., B.Se., F.Z.S.: The Hrdrords. By Mr. Ritchie - - - - - - - 42-68

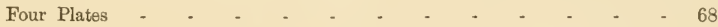

A Large Tubularian (Tubularia regalis) from the Moray Firth. By Professor Thomson 69-74

Note on a Large Axtipatharlan froy the F玉roes. By Professor Thomson - - 75-81

Plate - $\quad$ - $\quad$ - $\quad$ - $\quad$ - $\quad$ - $\quad$ - $\quad$ - $\quad$ - 81

Report on the Marine Biology of the Sudanese Red Sea: The Alcronarians. By Pro-

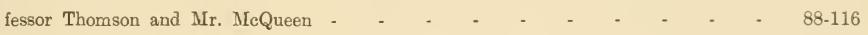

Four Plates - $\quad$ - $\quad$ - $\quad$ - $\quad$ - $\quad$ - $\quad$ - $\quad$ - 115

Note ox a Remarkable Alcyonarian, Studeria mirabiuis. By Professor Thomson - 117-124

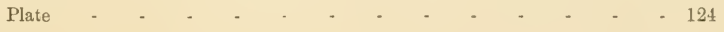



The Hydroids of the Scottish National Antarctic Expedition. By James Ritchie, II.A., B.Sc., Fullerton Scholar, University of Aberdeen. Communicuted by W. S. Bruce, F.R.S.E. (With Three Plates.)

(MS, received Mlay 1, 1905. Read June 21, 1906. Issued sefiarately March 16, 1907.)

The collection of Hydroids hereafter deseribed was made in the years 1902-4 by the Scottish National Antarctic Expedition ship Scotia, during her cruises in Antarctic and sub-Antaretic seas.

For the opportunity of examining the specimens I am indebted to $\mathrm{Mr} \mathrm{W}$. S. BRuce, the energetic leader of the expedition; and I also wish to thank Professor J. Arthur THomson for much assistance and advice in the eourse of my work.

The collection, as here described, contains 41 specimens, of which 33 are referable to 27 known species distributed among 15 genera, some of them being new varieties; while the remainder have required the establishment of 7 new species and 1 new genus. One specimen remains specifically undetermined. Thus there are in all 18 different genera, represented by 35 different species.

Before dealing with the detailed systematic aspect of these forms, a few general notes may be inserted:-

(1) The habitat of the forms shows considerable diversity. Sixteen of the specimens were associated with Alcyonarians, being found along with, or growing upon, those forwarded to Professor Thomson for identification; eight oceurred upon larger Hydroids; while two were crecping upon seaweed fronds. Sponges formed the foundation upon which several of the remaining colonies were erected.

(2) With the specimens were associated many types of life. Frequent diatoms and foraminifera lay within the hydrothece or upon the stems; various sponges rested upon or surrounded some of the branches; and there were also numerous elimbing or encrusting polyzoa, a few eirripede galls, and oecasional pycnogonids.

(3) Of new forms described the most interesting is one of those rare types, apart from the Plumularians, in which distinct nematophore structures have heen found (Allman, 1883, p. 6; Quelch, 1885, p. 4), and for it we have formed a new genus, which we have named Brucella in honour of Mr Broce. The beatiful, highly specialised coppinia-gonosome of this type indicates elose atfinities with the fumily Lafoëidæe in which it has been placed.

(REPRINTED FROM THE TR.ANSACTIONS OF THE ROYAL SOCIETY OF EDINBURGH, VOL. XLV., PP. 519-545.) 
(4) Another new form, belonging to the genus Staurotheca, is also worthy of mention as showing a development of the decussate arrangement of hydrothece, which necessitates a slight modification in the generic characters as originally described by Allman (1888, p. 75).

(5) The occurrence among the specimens of the coppinia-gonosome of Grammaria, which has only within the last few months been described by Hartaud (1905, p. 597), is of interest, since the peculiar structure of this gonosome aggregate necessitates the transference of the genus from the neighbourhood of the Sertulariidæ, where it had been placed by ALLmax in 1888 , to close proximity with the far-removed Lafoëidæ.

(6) Throughout the genus Halecium, here represented by five species, the occurrence of minute, translucent points round the rim of the hydrotheca has been noted (Pl. II. fig. 5). These points, whose use Aluman did not happen to observe, are small, domeshaped thickenings on the inside of the perisarc, placed in a ring just above the base of the hydrotheca, and to these are attached short strands from a disc-like portion at the base of the polyp, which is thus moored to the walls of its insignificant hydrotheca. Such refringent puncta are not confined to the Haleciidæ, for similar structures in the same position-just above the floor of the hydrotheca-were observed in the hydrothecre of Obelia geniculuta.

(7) The Scotia collection contributes also to our knowledge of the geographical distribution of Hydroids. Thus to the already wide distribution, Aretic to Antarctic, of such forms as Lafoëa gracillima (Spitsbergen, Norwegian coasts, British coasts, Magellan Straits, etc.) or Obelia geniculata (Norwegian coasts, British coasts, French coasts, Kerguelen, etc.), still another locality is added, while several new records have been made of the occurrence of less common forms.

(8) As a remarkable case of associated distribution we may refer to Siliculariu hemispharica, a simple Campanularian form, which has been recorded from three different localities, namely, Falkland Islands (Allman, 1888), Navarin Island, Tierra del Fuego (Hartlaub, 1905), and Gough Island (Scotia), and in each case it was found in elose association with Obelia geniculata.

In classifying the specimens according to their geographical occurrence, the regions mapped out by Ortuann (1896) and made use of by Professor Hartlaub (1904) have been adopted. Taking these as our standard, we find that ten of our specimens fall into the Antaretic Pelagic Region, all belonging to the Southern Subregion, while twentynine, including all the new forms, have been found in the Antaretic Littoral Region. The remaining two were obtained at St Helena.

Before dealing with the systematic aspect of the collection, I should like to express my special indebtedness to Professor Hartlaub's "Hydroiden der magalhaensischen Region und chilenischen Kiiste" in the Zoologische Jahrbücher (1905), and to Professor Nutring's excellent monographs on the American Hydroids (1900 and 1904). 
Arranging the Scotic specimens according to the localities in which they were obtained, we get the following list:-

\section{Antarctic Pelagic Region.}

(it) Antarctic circumpolar subregion.

Nil.

(b) Southern circumpolar subregion.

Burnwood BANk, $54^{\circ} 25^{\prime} \mathrm{S} ., 57^{\circ} 32^{\prime}$ W. 56 fms. 1st December 1903.

* Heliella striata, Allm.

* Calycella syringa, Linn.

Lafoëa antarrtica, Hart.

- " yrarillima (Alder).

* Grammurir mayellanica, Allm.

* Halerium beanii, Johns.

* Synthecium robustum, Nutt.

* Sertularella filiformis, var. reticulata, 12. var.

* " $\quad$ tenella, Alder.

* $\quad$ " trínspillata, Alder.

Antarctic Littoral Region.

FalkLaxd Islandos.

(a) Port Stanley. 8th January 1903.

* Campanularia ungulata, Hinks. , tincta, Hinks.

Sertulurella contorta, Kirch.

Plumularia magellanica, Hart.

(b) Cape Pembroke. January 1903 to January 1904.

Sertularella conterta. Kirch.

South Orkney Istands.

(a) MacDougall Bay. Novemher 1903.

Obetia lonyissima, Pall.

(b) Scotia Bay. 25th March and 6th Decemher 1903.

Campanuluria, sp.

Obelia longissima, Pall.

* Halecium interpolatum, n. sp.

* Staurotheca reticulata, n. sp.

* Sertularella rertitheca, $n$. sp.

Station 411, off Coat's Land, $74^{\circ} \mathrm{I}^{\prime} \mathrm{s}_{\text {., }} 22^{\circ} 0^{\prime} \mathrm{W}$. 12 th March 1903.

Hebella striata, var. plana.

Halecium robustum, Allm.

Gough Istand. 22nd April 1904.

Siliculari, hemispherica, Allm.

Ubelia genirulata, Linn.

* Brucella armata, nov. gen. et sp.

Halecinm tenellum, Hinks.

Sertularella gayi, Lamx.

Cape Colony.

(a) Caje Town Docks. May 1904.

Plumularia echinulata, Lank.

" pinnata, Linn.

* Indicates a new record for the Geographical Region.

(ROX. SOC. EDIN, TRANS,, VOL, XLV., 521.) 
Cape Colony-cont.

(b) 8 miles X. of Dassen Island. 18th May 1904.

Sertularella filiformis, var, reticulata, n. var.

(c) Saldanha Bay. 21st May 1904

* Podocoryne carnea, Sars.

* Halecium halecinum, Linn.

Thujaria pectinata, Allm.

Sertularella arborea, Kirch.

* Antennularia hartlauli, n. sp.

* Autennopsis scotio, n. sp.

* Plumularia unilateralis, n. sp. Aglaophenia dichotoma (Johns.).

Si Helena.

Halecium robustum, Allm.
,,$\quad$ tenellum, Hinks.

The systematic grouping of the species represented in the scotia collection is as follows :-

\section{GYMNOBLASTEA.}

Family Podocorynide.

Podocoryne carmea, Sars, 1846.

\section{CALYPTOBLASTEA. Family HaLecind E.}

Halecium beanii, Johns., 1847.

, halecinum, Linn., 1758.

Halecium tenellum, Hinks, 1861.

, robustum, Allm., 1888.

, interpolatum, n. sp.

\section{Family Campanularide.}

Cempanularia angulata, Hinks, 1861.

, tincta, Hinks, $1 \& 61$.

, sp.

Ohelia geniculata, Linn., 1758.

" longissima, Pall., 1766.

Lafoëa antarctica, Hartlaub, 1905. , gracillima (Alder, 1857).
Silicularia hemispharica, Allm., 1888 . Hebella striata, Allm., 1888.

," striata, var. plana, n. var. Calycella syringa. Linn.

\section{Family LAFoĖids.}

Grammaria magellanira, Allm., $188 \varepsilon$.

Brurella armata, n. gen. et sp.

\section{Family Sertilarind..}

Sertularella arborea, Kirch., 1884. contorta, Kirch., 1884.

" filiformis, var. reticulate, n. var.

Sortularella tricuspidata (Alder, 1856). , rectitheca, n. sp.

Thujaria pectinata, Alln., 1888.

Synthecium robustum, Nutt, 1904. gayi, Lamx., 1821.

, tenella (Alder, 185i). 


\section{Family Plumulariod.}

Aglaopheniu dichotoma (Johns.). Plumularia echinulata (Lamk., 1836). " magellanica, Hart., 1905.

" pinnata, Limn.
Plumularia unilateralis, n. sp. Antennularia hartlaubi, n, sp. Antennopsis scotix, n. sp.

\section{GYMNOBLASTEA.}

\section{Family Podocoryin.e.}

Podocoryne carnea, Sars, 1846.

Encrusting three Gasteropod shells from one locality there occur gymnoblastic colunies which cannot be separated from the above species. The nutritive hydranths bear from 8 to 15 tentacles, 12 being most common, while the gonophore-bearing individuals possess only 5 or 6 . All the hydranths are in a contracted state, some of the larger measuring about $0.8 \mathrm{~mm}$. in height. Short chitinous spines stud the investing crust at irregular intervals.

The gonophores are borne in threes or fours beneath the tentacles. The medusoir has 8 tentacles, 4 larger and 4 smaller.

Locality, etc.--On empty shells of Nassa erepidula from Saldanha Bay, Cape Colony. Trawl. 19th May 1904.

\section{CALYPTOBLASTEA.}

\section{Family HaLecidde.}

\section{Haleciun beanii, Johnstone, 1847.}

T'wo fragments occur, one 4 , the other $7 \mathrm{~cm}$. high. The characters of the species are well shown in the specimens; the polysiphonic stems and branches which distally become monosiphonic; the pinnate arrangement of the branches; the extreme delicacy of the ramuli, especially in the distal regions; the frequent tiers of hydrothece and the peculiar female slipper-shaped gonothecæ, with their openings placed medianly instead of at the extremity. In the present specimens, as in AlLMAN's (1888), only slipper-shaped gonothecæ occur. We note, however, that while the hydrothecre are in some cases set on a "short bresal ofliset from the distal end of each indernode" (AlLman, 1888 , p. 12 ), in the majority of cases the primary hydrotheca arises directly from and lies almost against the distal end of the internode, as figured by IIARTLAUB $(1905$, p. 606 , fig. $B^{3}$, a and b). From within these primary basal hydrotheca arise the tiers which are so common in the species.

Locality, etc.-Fathoms, 56. Date, 1st December 1903. Burdwood Bank. 


\section{Halecium halecinum, Linn., 1758.}

A thick clump of stout fascicled stems and branches from the entrance to Saldanha Bay. The stems and branches are truncated at an almost uniform height, are of a dark brown colour, and bear small, hydrotheca-bearing shoots of a pale brown, and evidently of younger age. The general appearance suggests that some agency having damaged the old-established branches, the colonies have made an effort to survive by sending out many small, much-branched shoots from the older and unharmed portions of the stem.

The architecture is similar to that described by Hinks. The hydrothecæ are alternate, one towards the distal end of each internode. They are generally sessile, as described and figured by BILLARD (1904, p. 161) for young branches, and frequently they contain the base of a tier of one or two secondary cups. Rarely in place of such a tier there arises a blind regenerative stolon, the true branches arising just below the hydrothecæ. Thus it comes about that a tier of hydrothecæ frequently appears in the angle between a branch and its offshoot. Small refringent points are present round the edge of the hydrotheca as in the other species of the genus (vide p. 525).

Gonosome.-The gonangia, of which only male are present, oceur in densely packed rows. They agree with Hixks's description and figure, being slenderly ovate and narrowing proximally into a short stalk with about two rings.

Locality, etc.-Entrance to Saldanha Bay, Cape Colony, in 25 fathoms Date, 21 st May 1904.

\section{Halecium robustum, Allman, 1888.}

A fragment of a strongly fascicled, upright, much-branched colony $5 \mathrm{~cm}$. in height. The branches lie roughly in one plane and are often bent at sharp angles, the older rising irregularly from the stem, while the younger are approximately alternate, and arise from the side of the proximal segment of the hydrotheca. The internodes, which are long, but whose length raries from 0.6 to $1.5 \mathrm{~mm}$., are separated by slanting nodes and bear at their distal ends alternate hydrothecæ $0.2 \mathrm{~mm}$. in diameter from margin to margin, adnate at one side to the internode, with an insignificant, non-everted limbus, and rarely with a tier of one or two secondary hydrothecæ. The proximal ends of the internodes are marked by slight annulations. Around the inside of the limbus are situated small, light-refracting prominences, to which, as in the other members of the genus, are attached strands keeping in place a fleshy disc at the base of the hydranth which cuts off the perisarcal cavity from the exterior. The hydranths are large and have a great number of tentacles.

fronosome.-Not present.

Localities, etc.- (a) Station 411, off Coat's Land. Lat., $74^{\circ} 1^{\prime} \mathrm{S}$; long., $22^{\circ} 0^{\prime} \mathrm{W}$. Depth, 161 fathoms. Surface temperature, 28 9 . Date, 12th March 1904. (b) St Helena.

The specimens differ from that figured by AlLMax (1888) in that the branches (ROY. SOC. EDIN. TRANS., VOL, XLV., 524.) 
frequently have at their bases at least one athecate internode connecting the stem process with the hydrophore-bearing portions of the branch. The present specimens are also frequently annulated, while Allmax's figures indicate that the original was smooth.

\section{Halecium tenellum, Hinks, 1861. (PI. II. fig. 4.)}

Several specimens of an extremely delicate and graceful hydroid colony, growing in bunches on the exposed axis of an Aleyonarian, are referable to this species. As Hixks's description appears to be rather vague, 1 give a detailed description of the specimens. The colonies are short, generally about $15 \mathrm{~mm}$. in length, with unfascicled stems and irregular branches, which arise from the distal ends of the internodes, and in some cases, at least, from the base of a hydrophore. The branches lie for the most part in one plane.

The stem is thin, having near its base a diameter of a little over $0.1 \mathrm{~mm}$, and, like the branches, it is divided into long slender internodes whose length varies between 0.8 and $0.9 \mathrm{~mm}$. The internodes are separated by slanting nodes, between which the stem zigzags, and on each side of which are annular constrictions. The hydrothecæ, which are alternate and lie in one plane, are borne on short processes at the distal ends of the internoles. They are cylindrical, trumpet-shaped, with a large, beautifully everted limbus, and are usually prolonged by several similar segments (from two to five in number), at the bases of which, on a level with the margin of the next lower limbus, arise well-marked annulations. The diameter of a limbus from margin to margin is $0.15 \mathrm{~mm}$.

The fleshy parts are in good condition, and the following points were observed:The hydranths are large and not wholly retractile, measuring, from mouth of hydrotheca to summit of hypostome, when extended, $0.3 \mathrm{~mm}$. Just above the neck there is a well-defined bulge, and above this again a dise, from the margin of which arise the tentacles, about sixteen in number, enclosing the conical hypostome. Across the interior of the hydrotheca, at the level of the base of the everted limbus, stretches a Hattened fleshy dise supported by a perisarcal septum through which, by a small aperture, the coenosare passes. The dise is moored in its place by numerous delicate strands attached to the perisare at rather irregular intervals. It the points of attachment there arise from the limbus small, dome-shaped prominences, which, refracting the light, appear as minute, clear dots - the "refringent puncta" of the Challenger Report. The prominences are rather irregularly arranged just above the level of the septum, on which the coenosareal dise lies, and vary in number from about sixteen to twenty on each limbus.

Gonosome.-The gonangia are ovate, broad in the proximal region, obtusely pointerl in the distal. They are supported on short stalks which arise from the sides of the hydrothecæ, and always from the lowest segment in any hydrotheca-tier. They are $0.9 \mathrm{~mm}$. in length by $0.45 \mathrm{~mm}$. in maximum diameter. 
Localities, etc.-(a) Growing on the axis of an Alcyonarian (Thouarella), and dredged off Gough Island, lat. $40^{\circ} 20^{\prime} \mathrm{S}$, long. $9^{\circ} 56^{\prime} \mathrm{W}$., at a depth of 100 fathoms. Date, 22nd April 1904. (b) St Helena.

\section{Halecium interpolatum, n. sp. (Pl. I. fig. 3; Pl. II. fig. 3.)}

A number of colonies, the largest about $4 \mathrm{~cm}$. high, have been found in a shorepool. The colony is fascicled for the most part, but becomes monosiphonic distally. In the older colonies the lower portion of the stem, which is less than $1 \mathrm{~mm}$. in diameter, is usually destitute of important branches, while the upper portion bears long flexuous branches, often $15 \mathrm{~mm}$. in length, which leave the stem at acute angles and in different planes. This structure gives the colonies the appearance of a miniature tree. The branches arise either singly from the basal segment of a hydrotheca or directly from the hydrocaulus, in diverging pairs, one being at a slightly higher level than the other.

The stem and branches are divided into slender internodes of very different lengths, varying from orer $1 \mathrm{~mm}$. to $0.4 \mathrm{~mm}$., and marked at both ends by an annulation. The hydrothecæ are alternate, and are borne at the distal ends of the internodes, two thecate internodes being almost invariably separated by one or more athecate internodes. Very frequently a short, annulated, hydrotheca-erowned branch arises from the basal segment of a primary hydrotheca. The hydrothecæ are usually simple, consisting of a strongly annulated peduncle about $1 \mathrm{~mm}$. long, surmounted by a well-everted limbus measuring $0.2 \mathrm{~mm}$. from margin to margin. Oceasionally a second limbus arises on a short stalk within the first. Around the limbus occurs the row of refringent prominences found throughout the genus, and here, as in the other cases which have been examined, they serve as attachment points for strands supporting a dise at the base of the polyp.

Ionosome.-Not present.

Locality, etc.-Off rocks in shore-pool. Temperature, $30^{\circ}-32$. Scotia Bay, South Urkneys. 6th Deeember 1903.

One of the branches ended in peculiar, stolon-like outgrowths, as is shown in fig. 3, Pl. II. The specimens, which have probably been cast by some storm into the shorepool in which they were found, are in poor condition, being almost wholly overgrown by polyzoa. The specific name is intended to suggest the presence of the characteristic athecate intermediate internodes.

\section{Family Campanularird.£. \\ Campanularia angulatu, Hinks, 1861.}

Several specimens about $1 \mathrm{~cm}$. high were found creeping ou an alga. The specimens agree with Hinks's description :- slightly branched stems ringed above the origin of the pedicels; strongly ringed pedicels, usually with nine rings, sometimes with only about 
five, and tapering somewhat towards their distal ends; hydrothecæ campanulate, even-rimmed, usually on long pedicels. In the present specimens there are present none of the tendril-like stolons mentioned by most writers, but this is not surprising, since in most cases the distal end of the colony is awanting.

Gonosome.-Not present.

Locality, etc.-Port Stanley, Falkland Islands; 64 fathoms. 3rd February 1904.

\section{Campanularia tincta, Hinks, 1861.}

This species is represented from one locality, that from which HartLaUB (1905) has described his specimens. The Scotia specimens, while apparently belonging to this species, show a considerable resemblance to $C$. cylindrica, Allm. (1876, p. 114), from which they differ in their diminutive size and in the absence of ringing at the base of the peduncle. The present specimens, which are from 1.5 to $2 \mathrm{~mm}$. high, have a corrugated peduncle averaging some $0.9 \mathrm{~mm}$. in height and surmounted by a ball-like segment which bears the hydrotheca. The hydrothecæ are about $0.7 \mathrm{~mm}$. long by 0.3 $\mathrm{mm}$. in diameter, almost cylindrical, and narrow sharply at the base. The margin is divided into twelve blunt teeth and is frequently marked by a regeneration line. The gonosome is awanting.

Locality, etc.-Creeping on weathered hydroid stems, Port Stanley, Falkland Islauds. $\quad$ 3rd February 1904.

$$
\text { Campanuluria, sp. (Pl. I. fig. 2.) }
$$

Lack of material forbids the assigning of a specific name to this form. Delicate simple stems about $3 \mathrm{~mm}$. high and $0.05 \mathrm{~mm}$. in diameter arise at irregular intervals from a creeping tubular stolon. The hydrothecæ are deep, campanulate, 0.8 $\mathrm{mm}$. in length by $0.5 \mathrm{~mm}$. in greatest diameter, with their cavity eut off from that of the stem by a distinct partition. Their margin is divided into twelve or fourteen teeth, a delicate line sometimes following the curves of the teeth just within the edge. The hydrothecæ, which are marked by delicate, longitudinal lines passing from the notches between the teeth to the base, are borne upon peduncles about $3 \mathrm{~mm}$. long with several rings at the top. These rings seem to be fairly constant, two deep constrictions giving rise to two ball-like divisions which are followed by an indistinctly ringed portion of the peduncle, cut off from the remainder, which is smooth, by another deep constriction.

Gonosome.-Not present.

Locality, etc.-Growing on Staurotheca reticuluta, Scotia Bay, South Orkneys. Depth, 65 fathoms. Date, 25th Narch 1903.

The specimen approaches $C$. IIinksii (Alder, 1857), but the typical campanulate form of the hydrothecæ, the blunt teeth, and the peculiar markings on the peduncle, distinguish it from the parallel-sided hydrothecæ, the square-topped teeth, and the 
characteristic ringing of $C$. Hinksii, where the first annulation is included in the base of the hydrotheca. From C. cylindrica, Allm., and C. tincta, Allm., it is also distinguished by its campanulate form and its peduncle characters.

\section{Obelia genieulata, Linnæus, 1758.}

Several specimens of this well-marked species were obtained growing on the fronds of a large seaweed-Macrocystis pyrifera.

The hydrotheca-bearing shoots, which are generally simple and average only $12 \mathrm{~mm}$. in height, arise from a creeping stolon which ramifies over the surface of the seaweed frond. The trophosome agrees with the description in Hnsks's British Hydroid Zoophytes, but here the annulations on the peduncle are rather more variable - two or three as well as a larger number being common. Within the hydrotheca, a short distance from the base, a perisarcal ridge is well marked, supporting the flattened basal portion of the polyp. Just above this bracket there occurs an irregular ring of minute refringent spots-small prominences on the inner side of the hydrotheca wall - to which the basal dise of the polyp is attached. These prominences resemble and serve the same purpose as those found throughout the genus Halecium (vide p. 525). The polyps are well preserved, and show well the large, trumpet-shaped proboscis.

Gonosome.-Absent.

Locality, etc.-Growing on the fronds of Macrocystis pyrifera, Gough Island. Lat., $40^{\circ} 20^{\prime}$ S. ; long., $9^{\circ} 56^{\prime} \mathrm{W}$. Date, 22 nd April 1904 .

\section{Obelia longissima, Pallas, 1766.}

A large number of weather-beaten colonies were found in the South Orkneys. The specimens are about $8 \mathrm{~cm}$. high and agree closely with Hinks's description and figures. The hydrothecæ are mostly awanting; those which remain are fragile and much crushed, and probably as a consequence I was unable to detect the blunt teeth which mark the rim. The pedicels, which taper towards the top, are usually altogether ringed, but sometimes only in the proximal and distal regions, the median portion being smooth. A pedicel was frequently noted springing from the axil between branch and branchlet, as mentioned by Hixks (1868).

Subsequent specimens, residue from the seaweed collections, were in better condition.

Gonosome.-Wanting.

Loculities, etc.- (a) Macdougall Bay, South Orkneys. November 1903. (b) Off rocks in shore-pool, Scotia Bay, South Orkneys. Temperature, $30^{\circ}$ to $32^{\circ}$. Date, 6 th December 1903.

The specimens from both localities appear to have been exposed to weathering for some time. Those from $(b)$ especially show traces of rough usage, the branches being 
broken off not far from their origin, while the greater number of the stems are covered with polyzoon growths.

Siticularia hemispherica $=$ Hypanthea hemispherica, Allman, 1888.

The only representative of this genus in the Scotia collection occurs on the frond of Macrocystis pyrifere, from Gough Island. The specimens bear out Hartlaub's opinion that the length of the peduncle, varying as it does to a considerable extent, is not a safe specific character, for here various peduncles measure $6,5,4,3,1 \mathrm{~mm}$. In so simple a genus distinctive specific characters are not easily obtained, but the following point to identity with S. hemispherica:-Hydrocaulus, ereeping, branched, bearing at varying distances pedunculate hydrothece and gonangia which usually alternate with one another. The peduncles are exceedingly variable in length, rather less in diameter than the hydrocaulus, with a distal swelling, succeeded by a globular segment, and this in turn by the hydrotheca. The hydrotheca is conical, almost as broad as long, about $0.7 \mathrm{~mm}$. high by $0.5 \mathrm{~mm}$. in greatest diameter, with a markedly oblique margin.

The gonangia are $2 \mathrm{~mm}$. long by $0.6 \mathrm{~mm}$. in diameter, narrowing slightly towards the opening, and considerably towards the base, where they are supported by a distinct peduncle. They are never grouped on the hydrocaulus.

Locality, etc. Creeping over the fronds of Macrocystis Pyrifera, Gough Island. Lat., $40^{\circ} 20^{\prime}$ S. ; long., $9^{\circ} 56^{\prime} \mathrm{WV}$. Date, 22nd April 1904.

\section{Hebella striata, Allman, 1888. (Pl. I. fig. 7.)}

Several specimens of the beautiful species described by Allman in the Challenger Reports occur creeping on the stems and branches of various larger Hydroids. The hydrothecæ are large, almost $1 \mathrm{~mm}$. in length by from $0 * 22$ to $0.25 \mathrm{~mm}$. in diameter, cylindrical, borne on short, untwisted peduncles varying in length from 0.25 to $0.4 \mathrm{~mm}$. In some the characteristic ringing exists only on the lower half of the wall, part towards the margin being smooth. The hydranths are in all cases contracted, and in this state occupy only the lower half of the hydrotheca. They are in good condition, and show in their contracted state a bulging body, separated from a fleshy dise at the base of the hydrotheca by a marked constriction, and surmounted by another constriction from above which arises a whorl of tentacles. Within the tentacles there arises a conical hypostome.

Gonosome.-Not present.

Locality, etc.-Creeping on the stems and branches of Lajoëu gracillimu, Grammaria magellanica, Sertularella filiformis, Burdwood Bank. Lat., $54^{\circ} 25^{\prime} \mathrm{S}$. ; long., $57^{\circ} 32^{\prime}$ IV. ; 56 fathoms. 1st December 1903. 


\section{Hebella striata, var. plana, n. var. (Pl. I. Fig. 8.)}

A colony creeping upon Halecium robustum, whose habit and general appearance resemble those of $H$. striata. The hydrothecæ, however, are rather larger, $1: 3$ to 1.4 $\mathrm{mm}$. in length by $0.28 \mathrm{~mm}$. in diameter, and show no hint of the annular thickenings of perisare which form the characteristic striations. Marginal reduplications were noted in some cases, while a solitary peduncle was marked by a thickened ring near its base.

Gonosome.-Not present.

Locality, etc.-Creeping on the stems and branches of Halecium robustum, from Station 411 . Lat., $74^{\circ} 1^{\prime} \mathrm{S}$. ; long., $22^{\circ} 0^{\prime} \mathrm{II}$. Depth, 161 fathoms. Surface temperature, $28^{\circ} \cdot 9$. 12 th Narch 1904 .

In none of the true $H$. striata colonies did there occur hydrothecæ with more than about a third of their surface smooth, the remainder of course being striated, and even these were exceptional. Hence an entirely smooth hydrotheca seems worthy of being considered a distinct variety.

\section{Calycella syringa, Linnæus, 1758.}

Arising from a tubular, creeping stolon are several minute, extremely delicate, almost campanulate hydrothecæ whose cavities are separated from those of their peduncles by thin partitions. They are operculated, and are borne on peduncles of variable length which are always marked by many strong annulations.

The absence of gonosomes and the unsatisfactory state of the hydranths render accurate identification impossible, but the trophosome agrees with Hinks's (1868) description of C. syringa, except in that the "horn-colour" is lacking.

Mectsurements.-Hydrotheca : length, including operculum, $0.2 \mathrm{~mm}$. ; diameter, 0.1 mm. Peduncle: length, $0 \cdot 2 \mathrm{~mm}$.

Locality.-Burdwood Bank. Lat., $54^{\circ} 25^{\prime}$ S.; long., $57^{\circ} 31^{\prime}$ W. 56 Fathoms. 1st December 1903.

\section{Family LaFoëId E.}

\section{Lafö̈a antarctica, Hartlaub, 1904.}

The above species occurs on the stems and branches of Sertularella filiformis. It agrees in all respects with the description given by HartLaub. The large number of the regeneration rings on the hydrothece is especially noticeable-six being not unusual. The length of the hydrothecæ, from where they leave the stem at right angles, to the margin, averages 5 or $6 \mathrm{~mm}$., while the diameter is about $1.25 \mathrm{~mm}$.

Locality. etc.-Creeping on the branches of Sertularella filiformis, from Burdwood Bank. Lat., $54^{\circ} 25^{\prime} \mathrm{S}$. ; long., $57^{\circ} 32^{\prime} \mathrm{W}$. Fathoms, 56. Date, 1st December 1903.

Previous Locality. $-70^{\circ} 23^{\prime}$ S. ; $82^{\circ} 47^{\prime} \mathrm{II}$. 


\section{Lafoëa gracillima (Alder, 1857).}

Several specimens referable to this species occur growing on the horny axis of an Aleyonarian. They agree in all but size with the specimens described by Bonnevie (1899), the largest reaching a height of only $3 \mathrm{~cm}$., while the general size lies between 2 and $3 \mathrm{~cm}$. The colonies are erect and branched, without any distinct stem, the greater number of the branehes lying in one plane and showing a tendency to be more strongly developed on one side. Except towards the tip, where they are monosiphonic, the branches are fascicled. The hydrothees are long narrow cylinders $0.5 \mathrm{~mm}$. in length by $0.1 \mathrm{~mm}$. in greatest diameter, sometimes with reduplication rings round their margins. They arise irregularly from all sides of the hydrocaulus, and are borne on loosely twisted peduncles bearing two turns of a spiral.

Gonosome.-Not observed.

Locality, etc.-Growing on the axis of an Alcyonarian (Gorgonid) in 56 fathoms. Date, 1st December 1903. Burdwood Bank. Lat., $54^{\circ} 25^{\prime} \mathrm{S}$.; long., $57^{\circ} 32^{\prime} \mathrm{W}$.

\section{Grammaria magellenica, Allman, 1888. (Pl. I. figs. 4, 4A.)}

Three colonies varying in height from $6 \mathrm{~cm}$. to $16 \mathrm{~cm}$, and in breadth from $7 \mathrm{~cm}$. to $12 \mathrm{~cm}$. The stem is fascicled and thick, reaching just above the base a diameter of about $3 \mathrm{~mm}$. and gradually tapering towards its summit. In two of the speeimens it divides about $1 \mathrm{~cm}$. above the base into two or three equally dereloped, strong branches, and these, together with the stem itself in the other speeimen, bear along their length usually alternate ramuli, which sometimes reach a length of $14 \mathrm{~cm}$. These primary ramuli bear secondary, and these again may bear tertiary, pinnæ-bearing branches. On all the branches, and on the main stem between the branches, there are alternately-set pinnæ usually between $10 \mathrm{~mm}$. and $15 \mathrm{~mm}$. in length, which become greatly constricted at their point of origin. All the branches and pinnæ lie in one plane, and in the largest specimen anastomosis occasionally occurs between them. The hydrothecæ are placed in suceessive planes, in whorls of three, which alternate with one another so that there are six longitudinal rows on the colony. They are cylindrieal, and have a circular opening with an even, non-everted margin.

Gonosome.-The gonangia are grouped together into irregular bunehes which surround portions of the stem and the bases of such branches as arise from these portions. In the largest of the three colonies two bunches of clusterer gonangia were found, the larger $30 \mathrm{~mm}$. long by $3 \mathrm{~mm}$. in diameter, the smaller $20 \mathrm{~mm}$. long by about 2 mm. in diameter, while on another colony a still smaller cluster occurred. These coppiniæ are elongated clusters of compressed gonangia growing closely around the stem for a cousiderable distance, and bristling with minute projecting tubes which are without the irregular bendings figured by Hartlats (1905). Under the microscope the eluster resolves itself into a large number of hexagonal eells, elosely resembling honey- 
comb-the compressed gonangia - from among which spring many short, uncoiled tubes 0.4 to $0.5 \mathrm{~mm}$. in length.

Locality.-Burdwood Bank. Lat., $54^{\circ} 25^{\prime}$ S.; long., $57^{\circ} 32^{\prime}$ II. Depth, 56 fathoms. 1st December 1903 .

As the species was named by ALLMax from small fragments, and as subsequent specimens collected by PAEssLer in 1893 off Australia were also fragmental, I have thought it necessary to give a rather full account of the structure of the colony to supplement the original description. Since HARTLAUB figures only longitudinal and transverse sections of the coppinia (HARTLAUB, 1905, p. 597), representations of the general appearance and magnified surface riew have been here included.

Brucella, nor. gen.

We have named this genus after Mr Broce, the leader of the expedition.

Generic Characters. Trophosome.--Stem and branches fascicled for the most part, becoming monosiphonic distally; consisting of au axial tube predominantly hydrotheca-bearing, surrounded by peripheral tubes which may occasionally bear hydrothecæ and nematophores. Hydrothecæ tubular, fastened by their bases to a process of the hydrocaulus, their cavity being distinctly differentiated from that of the peduncle. Each hydrotheca is accompanied by a basal pair of nematophores.

Gonosome.-A coppinia, that is, a bunch of clustered gonangia surrounding the hydrocaulus, from which a number of delicate tubes arise.

The genus shows aftinities with Perisiphonia, Allman (Allman, 1888, p. 43) and Zygophylax, Quelch (Quelch, 1885, p. 4). From the former it can be distinguished by its manner of fascicling, its arrangement of nematophores, and, perhaps not so certainly, by the shape of the hydrothecx. The chief points of difference are summarised in the following table:-

\section{Perisiphonia.}

Axial tube completely enveloped.

No hydrothecæ on peripheral tubes.

Nematophores frequent and regular on peripheral tubes.

Nematophores present or absent from axial tube.

Hydrothecæ flask-shaped.

\section{Brucella.}

Axial tube not completely enveloped.

Scattered hydrothecæ on peripheral tubes.

Nematophores scattered and irregular on the peripheral tubes.

Two nematophores at base of each hydrotheca on axial tube.

Hydrothecæ tubular.

From Zygophylax, to which it is closely allied, it can readily be distinguished by the distinct differentiation of the hydrotheca cavity from that of the peduncle, and by the seattered nematophores on the peripheral tubes.

A portion of a specimen when softened in eaustic potash and dissected, showed a central, predominantly hydrotheca-bearing tube, surrounded by peripheral tubes, which were sometimes simple, sometimes branched, and sometimes bearing scattered hydrothece and nematophores. The structure of the fasciculation seemed to resemble that 
in Sertularella gayi as deseribed by Nutring, 1904, p. 6, although I found difficulty in tracing the peripheral tubes to their origin. The peripheral tubes certainly never become hydrotheca-bearing to the same extent as in Sertularella gayi.

The characters of the trophosome, and especially of the gonosome, appear to indicate elose relationship with the Lafoeidæ, in which family the genus has accordingly been placed.

\section{Brucelle armata, n. sp. (Pl. II. figs. 2A, 2B, 2c.)}

Several specimens have been obtained of a colony for which the above new genus has been formed. The colonies, which are erect and much branched, with both stem and branches thickly fascicled, reach in some eases a height of $6 \mathrm{~cm}$. by a similar breadth. Owing to this great breadth, as compared with height, and to the fact that the many branches lie in one plane, the colony assumes a somewhat flabellate appearance. It is of a pale brown colour, becoming lighter towards the tips of the branches. Except distally, where for a short distance they become monosiphonic, the stem and branches are fascicled, consisting of an axial tube, predominantly hydrothecabearing, surrounded by peripheral tubes which may bear oceasional hydrotheeæ and seattered nematophores. The main branches, which may reach a length of $5 \mathrm{~cm}$., leave the stem at irregular intervals, although frequently there is an approximation to alternate arrangement, while those borne by the main branches are regularly pinnate and alternate and are rarely branched. All the branches lie in one plane, and arise from below a hydrotheca, which then lies in the axil of the branch. The eavity of the axial tube is continuous; the tube is not divided into internodes, but bears alternately at regular intervals small processes to which the hydrothecæ are attached. The hydrothece are biserial, alternate, tubular, with an entire margin which is not parallel to the axis of the hydrocaulus. Their upper side is curved, while the lower is almost straight, and their cavity is eut off from that of the rest of the colony by a strong septal ridge at their junction with the hydrocaulus process. Above this occur one or two delicate, membranaceous intrathecal septa apparently stretching across the cavity of the hydrotheca, while near the edge there are usually two or three lines indicating the presence of marginal reduplications. The length of the hydrothece from basal septum to margin is between 0.3 and $0.35 \mathrm{~mm}$, while the greatest diameter is from 0.13 to $0.15 \mathrm{~mm}$. Towards the base they become constricted and rest upon a short process of the hydrocaulus, from each side of which springs a nematophore. The nematophores are small, only $0.1 \mathrm{~mm}$. long by $0.04 \mathrm{~mm}$. in diameter, and resemble those found in some of the Eleutheroplean Plumularians, consisting of two joints, the proximal, a narrow tube, the distal, a wirler tube opening out slightly towards the margin, round which there is frequently a reduplication line. This whole two-jointed structure is sometimes loosely ineased in an unjointed tube. Scattered nematophores of similar structure oceur frequently but irregularly on the peripheral tubes. The form of the hydranth could not be distinguished. 
Gonosme.-On one specimen were found two clusters of gonangia, the larger measuring $5 \mathrm{~mm}$. in length by $3 \mathrm{~mm}$. in diameter, the smaller $5 \mathrm{~mm}$. by $2 \mathrm{~mm}$. The clusters or coppiniæ form elongated ovals surrounding the stem and the bases of branches in the neighbourhood. They consist of numerous gonangia so closely packed that the sides become compressed and the whole assumes a honeycomb-like structure consisting of a dense mass of polygonal, usually hexagonal, cells, the majority of which communicate with the exterior by an exceedingly short tube. Issuing from this gonangial eluster are frequent tubes of various shapes; a few, especially at the ends, are merely two-jointed tubes like cauline nematophores with their basal joint elongated, while the majority consist of a longer tube $1 \mathrm{~mm}$. in length bearing alternate biserial nematophore-like lodies identical in structure with the nematophores on the trophosome.

Locality, etc.-Growing on the axis of an Alcyonarian (Gorgonid), and dredged off Gough Island, lat. $40^{\circ} 20^{\prime} \mathrm{S}$., long. $90^{\circ} 56^{\prime} \mathrm{W}$., at a depth of 100 fathoms. Date, 22nd April 1904.

The colonies were growing on the horny axis of a Gorgonid Alcyonarian, and appear to have been lying untenanted for some time, for not only has the coenosarc almost wholly disappeared, but foraminifera frequently occur within the hydrothecr, while barnacles and polyzoa, including a beautifully ringed, snake-like form, Anguinaria spatulata - a rare British species-occur growing on the colony.

\section{Family Sertulariide.}

Sertularella arborea, Kirchenpauer, 1884.

This species is represented by some colonies growing on lamellibranch shells, the largest reaching a height of $8 \mathrm{~cm}$. The specimens possess the characteristics described by Hartlaub (1900):-Compound stems and branches; branches pinnate and alternate, arising beneath a hydrotheca and divided by slanting nodes into very short, stout internodes, each of which bears a hydrotheea ; hydrothecæ adnate for about two-thirds of their length, with walls of unequal thickness and hints of intracalycine teeth; margin divided into four small, equal teetl. Gonotheca very long (about $3 \mathrm{~mm}$.) and narrow, often smooth, sometimes with faint signs of ringing, usually bearing at the distal end four minute teeth, and always arising from between the internode and the side of the hydrotheca near the margin. The specimens show no variations which have not been noted by Hartlatb (1900).

Locality, etc. - Entrance to Saldanha Bay, Cape Colony; 25 fathoms. Date, 21 st May 1904.

Sertularella contorta, Kirehenpauer, 1884.

Several specimens of this species have been obtained from two localities. They are bushy colonies reaching to a height of slightly over $7 \mathrm{~cm}$., almost destitute of branches 
near the base, but profusely branched distally. Except in the following unimportant details, the specimens agree with those previously described. While the annulations at the bases of the branches are well marked, the constrictions in the internodes are neither so frequent nor so distinct as those of former specimens. The gonangia closely resemble those described and figured by Notrivg $(1904$, p. 85). The annulations vary in number, in some cases disappearing altogether in the proximal portion of the gonangium. The teeth at the summit of the gonangium also vary in number; sometimes they seem to be absent, as in Kinchenpaukr's specimen (1884), sometimes two are present, as deseribed by NutTing, but in the present specimens three is also an occasional number.

Localities.- (a) Falkland Islands, Port Stanley. Date, 8th January 1903. Cape Pembroke ; shore. January 1903 to January 1904.

It is interesting to note that the present specimens were found in the same locality as were those from which the original description of the species was made by KIRCHENPACER some twenty years ago.

\section{Sertularella filiformis, var, reticulata, n. var.}

Several colonies referable to this species have been found, usually growing on polyzoon erusts, in two localities. Of the colonies, which are profusely branched and loaded with gonangia, those from locality $(\alpha)$ reach a height of from 5 to $6 \mathrm{~cm}$. while those from $(b)$ are considerably smaller. The hydrothecæ are adnate to the stem for $0.27 \mathrm{~mm}$. and free for $0.15 \mathrm{~mm}$., while at the opening their diameter is $0.15 \mathrm{~mm}$. They have three teeth, thus differing from Alluav's (1888) description, where two broad cusps are mentioned, and agreeing with Nutrivg's 1904) description of a portion of Alluan's specimen. The present specimens vary slightly from those described by NutTing in habit and in gonangia. The majority of those from $(a)$ and all the specimens from $(b)$ have closely interwoven and anastomosed branches, and thus present a matted, net-like appearance.

Gonosome.-The gonangia arise from each side of and just below the hydrothecæ. They are top-shaped, $1.7 \mathrm{~mm}$. long, with eight or nine large annular ridges, the widest portion occurring about the second or third ridge from the distal end, where the diameter, not including the ridge, is $0.7 \mathrm{~mm}$. They are surmounted by a tube 0.45 to $0.5 \mathrm{~mm}$. long, whose diameter gradually increases from base to margin, where it is $0.25 \mathrm{~mm}$. wide.

Localities, etc.-(a) Burdwood Bank. Lat., $54^{\circ} 25^{\prime}$ S.; long., $57^{\circ} 32^{\prime} \mathrm{W}$.; 56 fathoms. Date, 1st December 1903. (b) Eight miles north of Dassen Island, Cape Colony ; 35 fathoms. 18th May 1904.

\section{Sertularella gayi, Lamouroux, 1821.}

A strongly fascicled specimen $13 \mathrm{~cm}$. high by $7 \mathrm{~cm}$. broad is referable to this species. The general habit of the colony, with rigid stem $2 \mathrm{~mm}$. in diameter 
just above the base, and monosiphonie, roughly pinnate ramuli, is typical. The hydrothecæ are free distally for rather less than half their length, the free portion standing out from the stem almost at a right angle, and being marked on the upper side by a few rather indistinct annular rugosities.

Gonosome.-Not present.

Locality, etc.-Depth, 100 fathoms. Off Gough Island. Lat., $40^{\circ} 20^{\prime} \mathrm{S}$.; long., $9^{\circ} 56^{\prime} \mathrm{W}$. Date, 22nd April 1904 .

\section{Sertularella tenella (Alder, 1857).}

Small specimens of this delicate colony some $7 \mathrm{~mm}$. long have been found growing on Synthecium robustum. They are quite typical in appearance, agreeing with previous descriptions and figures.

The following are average measurements :-

Internodes.-Length from 0.55 to $0.8 \mathrm{~mm}$.

Hydrothecæ.-Length, $0.5 \mathrm{~mm}$; widest diameter, $0.25 \mathrm{~mm}$. ; diameter at margin, $0.15 \mathrm{~mm}$.

Gonosome.-Not present.

Locality, etc.-From off Burdwood Bank, lat. $54^{\circ} 25^{\prime} \mathrm{S}$, long. $57^{\circ} 32^{\prime} \mathrm{W}$., at a depth of 56 fathoms. Date, 1st December 1903.

\section{Sertularella tricuspidata (Alder, 1856).}

A slender, pinnately branched colony $7 \mathrm{~cm}$. high. It lacks the profuse branching and matted appearance of a typical specimen of $S$. tricuspidata, but in other respects it agrees elosely with the specific description.

Average Measurements.-Internodes: length, 0.75 mm. Hydrothecæ: height, $0.6 \mathrm{~mm}$.; portion adnate, $0.35 \mathrm{~mm}$.; portion free, $0.4 \mathrm{~mm}$.; diameter at margin, $0.3 \mathrm{~mm}$.

Gonosome.-Not present.

Locality, etc.-From off Burdwood Bank, lat. $54^{\circ} 25^{\prime}$ S., long. $57^{\circ} 32^{\prime} \mathrm{W}$., at a depth of 56 fathoms. Date, 1st December 1903.

\section{Sertularella rectitheca, n. sp. (Pl. I. fig. 5.)}

A small, delicate colony some $9 \mathrm{~mm}$. high, growing on the stem of Staurotheca reticulata. The stem is slender and unbranched, divided for some distance by slanting nodes into short regular internodes $0.5 \mathrm{~mm}$. long, and produced distally into a tubular tendril-like process which was attached to a portion of the Staurotheca colony. The internodes are much broadened half way up their length by a shoulder for the support of the hydrothecæ. These are alternate, cylindrical, about $0.5 \mathrm{~mm}$. high by $0.15 \mathrm{~mm}$. in diameter, adnate up to the distal end of the internode in which they arise, then free for the remaining third of their length. The hydrothecæ are straight, the free portion 
being in the same line as the adnate, the whole axis lying practically parallel to the stem. The margins of the hydrotheeæ are divided into three teeth, a small one on the adcauline edge, and two large and equal ones on the margin remote from the stem. The number of flaps in the operculum could not be counted.

Gonosome.-Not present.

Locality, etc.-Growing on Staurotheca reticulrta, Scotia Bay, South Orkneys. Depth, 65 fathoms. Date, 25th March 1903.

\section{Thujaria pectinata, Allman, 1888.}

A single specimen some $6 \mathrm{~cm}$. high almost completely enveloped in a dense polyzoon growth. The stem is unbranched and monosiphonie about $1 \mathrm{~mm}$. across, and is divided into equal internodes, each of which bears three pairs of opposite hydrothecæ. A pair of opposite pinnæ arise from each internode, originating between the proximal and median pairs of hydrothecæ. On the pinnæ the nodes are quite distinct, being marked by a constriction (in Allman's figure they are searcely indicated), and the hydrothecæ are arranged as on the stem-three pairs to each internode. The hydrothecæ are so closely approximated that the top of one touches the base of the next, but the "free membranaceous extension of the wall " has in every case been destroyed, leaving a rather ragged edge level with the general outline of the pinna. One of the pinnæ, instead of being thecate to the tip, was produced into a long, tubular, tendril-like process.

Gonosome.-Not present.

Locality.-Dredged at the entrance of Saldanha Bay, Cape Colony, in 25 fathoms. Date, 21st May 1904.

\section{Synthecium robustum, Nutting, 1904. (Pl. I. fig. 6.)}

About half-a-dozen specimens of this species have been dredged from the locality of Burdwood Bank. The average height is about $7 \mathrm{~cm}$., but two specimens are $11 \mathrm{~cm}$. high by $4 \mathrm{~cm}$. broad, almost twice the size of the specimen described by NutTing. The branches, which are regularly opposite, are simple in the majority of the specimens, but in some they rarely bear opposite branchlets; and not only in these branchlets, but even in the branches themselves, there is a distinct narrowing of the perisare immediately above each pair of hydrothecæ. The hydrotheeæ have frequently one or two annular striations-lines of reduplication-round their margins. Except in these details the trophosome agrees with Nutring's description.

Gonosome.-The gonangia differ somewhat from the dried specimens originally described. They are top-shaped, $2 \mathrm{~mm}$. long by $1 \mathrm{~mm}$. in diameter at the widest part. Distally they are strongly annulated, proximally they are almost smooth, while they are terminated by a low dome, the tubular neck of the original specimen being unrepresented. 
Locality, etc.-Burdwood Bank. Lat., $54^{\circ} 25^{\prime} \mathrm{S}$; ; long., $57^{\circ} 32^{\prime} \mathrm{W}$. Depth, 56 fathoms. 1st December 1903.

The occurrence in these specimens of branches sometimes simple and sometimes bearing pinnately arranged branchlets, appears to indicate that this character, upon which HartladB founded his S. chilense $(1905$, p. 671), is rather a variation than a character of specific value.

Staurothece, Allman, 1888 (modified).

Generic Character. Trophosome.-Hydrocaulus fascicled or unfascicled, bearing hydrothecæ in longitudinal rows and arranged in a series of transverse planes, each plane containing two or three hydrothecre which exactly alternate with those in the planes above and below them.

Gonosome.-Gonangia simple capsules springing from the hydrocaulus and destitute of marsupium.

This genus, as described by Allyax, must be slightly modified to include the specimen described below. The alternate arrangement of the successive series of hydrothecæ remains constant, but the generic characters must be widened to include not only opposite hydrothecæ, but also hydrothecæ arranged in whorls of three.

\section{Staurotheca reticulata, n. sp. (Pl. I. figs. 1, 1A, 1B.)}

A portion of a branched hydroid colony $8 \mathrm{~cm}$. in length by $4 \mathrm{~cm}$. in breadth. The stem, which is $0.5 \mathrm{~mm}$. in diameter, is unfascicled, and from it arise, at fairly regular intervals of $5 \mathrm{~mm}$., alternate flexuous branches of the same thickness as the stem, which zigzags between their bases. Smaller branches arise from these main branches and anastomose so frequently, sometimes by means of short, tendril-like processes, that free ends are absent except towards the margin of the colony. In some cases the free ends develop hydrorhizal tubes. All the branches lie in one plane, and this, together with the flabellate form of the colony and the prevalent anastomosis, gives the whole a remarkable net-like appearance, the regularity of the meshwork, at least near the stem, being increased by the fact that the main branches on each side of the stem lie roughly parallel. The internodes are irregular, generally containing about three pairs of hydrothecæ in the older branches, while in the younger there is usually a hint of a node between each pair.

The hydrothecæ are placed in longitudinal rows along the stem and branches. In the majority of the branches there are four rows, the hydrothecæ being arranged in opposite pairs, which are placed alternately at right angles with one another. Sometimes there are six rows - the hydrothecre in this case being placed in a succession of transverse planes, each plane containing three equidistant hydrothecæ, which exactly alternate with those in the planes immediately above and below them. The hydrothecæ themselves are cylindrical and deep, with a circular orifice and a smooth margin marked (ROY. SOC. EDIN. TRANS., VOL. XLV., 538.) 
sometimes by one or two lines of growth. They are $0.5 \mathrm{~mm}$. in height, and for $0.4 \mathrm{~mm}$. of this distance they are adnate, the free portion curving outwards from the stem.

Gonosome.-The gonangia are ovoid, 0.7 to $0.8 \mathrm{~mm}$. long, and $0.45 \mathrm{~mm}$. in diameter at the widest part, narrowing proximally and terminated distally by a circular orifice at the end of a short bulging prominence. They lie closely apposed to the stem for the greater part of their length, but can easily be detached, and arise on each side of, and just below, a hydrotheca. Thus although one or two gonangia most commonly oceur at one level, the full complement at a plane containing a pair of hydrothecæ is four, two to each hydrotheca.

The colony is of a horn brown colour.

Loculity, etc.-Obtained from a gripper on a sounding wire from Scotia Bay, Soutl Orkneys. Depth, 65 fathoms. Date, 25th March 1903.

\section{Family Plomulariod.}

Aglaopheniu dichotoma (Johns.), Kirchenpaner, 1872. (Pl. III. figs. 2, 2A, 2B, 2C.)

A large number of branched, fan-shaped colonies, $10 \mathrm{~cm}$. high by about $7 \mathrm{~cm}$. broad, with monosiphonic stems. The following details supplement Kirchenpauer's rather meagre description:- The branching, which is characteristic, is strictly dichotomous. The stem and branches are divided into short regular internodes $0.3 \mathrm{~mm}$. long, and from a nematophore-bearing process on each of these a hydroclade arises. The hydroclades, which are alternate and closely approximated, are borne on the front of the stem and leave it at an angle of about $45^{\circ}$. They also are divided into short regular internodes $0.3 \mathrm{~mm}$. in length, each with two strong septal ridges extending almost around their walls, one opposite and in line with the intrathecal septum, the other at the level of the bases of the supracalycine nematophores. The hydrotheca, which are closely approximated and obeonical, are tilted forward from the stem, the distal portion apparently being free. Their margin, which is not expanded or flaring, is divided into nine teeth, the anterior three being slightly larger and sharper, the middle one bent a little backwards. The intrathecal ridge is strong and oblique, in the same line as the corresponding internodal ridge, and reaching to the opposite wall of the hydrotheca. The supracalycine nematophores are not quite tubular. They are large and bulging, but do not reach to the margin of the hydrotheca, while the mesial nematophore, which is extremely narrow near the base but becomes wider distally, just reaches the level of the margin, the distal third of its length being free. The process arising from the stem and branch internodes, upon which the hydroclades are horne, bears about five nematophores similar in structure to those on the hydrotheca. The arrangement also is similar, one being merlian and proximal, while two are lateral and near the distal end of the process, but there are in addition a lateral and a basal pair.

Gonosome.-The corbula is oval, flattened laterally, $2 \mathrm{~mm}$. long by $1 \mathrm{~mm}$. in (ROY. SOC. EDIN. TRAXs., VOL. XLV., 539.) 
greatest diameter. It has five pairs of adnate costæ, each bearing from ten to twelve not quite tubular denticles along its length and an apparently unpaired, partly free, costa at the proximal end. On the corbula peduncle there is one hydrotheca.

Locality, etc.-The colonies were growing on a sponge, and were dredged at the entrance to Saldanha Bay, Cape Colony, in 25 fathoms of water. Date, 21 st May 1904.

\section{Plumularia echinulata, Lamark, 1836.}

Several colonies, the largest $3 \mathrm{~cm}$. in height, were found growing on sponges in the same locality as $P$. pinnata. The specimens differ somewhat from the type described by Hinks (1868) but seem to form a connecting link between $P$. echinulata, type and $P$. echinulata, var. pinnatöides of Billard (1904, p. 191 et seq.). The following points indicate a close relationship to the latter:-Stem internodes in the proximal portions of the colony sometimes bearing two hydroclades, while in the distal internodes, and more generally throughout the colony, only one hydroclade per internode is the rule; intermediate internodes in the hydroclades absent in the specimens examined; supracalycine sareostyle unprotected by a nematotheca, as described by Hinks; hydrothece deep; gonangia borne on stem. On the other hand, the fact that the margin of the hydrotheea does not reach the level of the succeeding node, and the presence of well-marked and frequent spines on the gonangia, indicate affinities with BillaRD's type.

The state of the material prevented observations on the condition of the axillary nematophores from being made.

Locality, etc. - Growing on sponges, coaling jetty, Cape Town Docks. May 1904.

\section{Plumularia magellanica, Hartlaub, 1905. (Pl. III. fig. 1, 1A.)}

The specimens collected by Mr Bruce differ somewhat in the structure of their hydroclades from the specimens of this peculiar species deseribed by HARTLAUB, but the difference is not of specific value. As in HARTLAUB's case, material is scarce.

The most complete colony is $15 \mathrm{~mm}$. in height, and consists of a stem $0.15 \mathrm{~mm}$. in diameter, divided by straight nodes into irregular internodes, each of which bears near its middle a single hydroclade. The hydroclades arise alternately from the stem nodes and are comparatively short - about $1 \mathrm{~mm}$. They are set upon a small process of the stem, from which the first thecate internode is separated by a narrow, somewhat ring-like, athecate internorle with slanting nodes. The thecate internodes are narrow at the base, and gradually widen distally until they finally seem to end in a rather shallow cup with expanded walls. From below this cup, and free from it, there arises in the distal portions of the colony a single short process, which bears again an expanding thecate internode from beneath whose hydrotheca another free process is given off, and so on, until each hydroclade bears from two to four or even five hydrothecæ. The 
marked angle at which each thecate internode lies with regard to the one preceding it, gives these simple distal hydroclades a helicoid-cyme-like appearance. In the proximal hydroclades - and here our specimens differ from HartLaub's - two processes arise below and at the opposite sides of the first hydrotheca, each of which bears a thecate internode, so that after the first hydrotheca the hydroclade possesses two diverging branches each similar to the simple distal hydroclades. Since the donble hydroclades arise laterally and not dorsally, as HARTLAUB describes, from their internode, it follows that their origins lie in a plane at right angles to the plane of the primary stem processes. The hydrothecx are shallow, with delicate, slightly expanded walls, and smooth margins. They appear to terminate the internode which bears them, are fixed only by their bases to their internode, and their walls are free. A single delicate, shovel-like nematophore lies in the centre of the internode beneath each hydroclade.

Gonosome.-Not observed.

The structure of the whole colony is extremely delicate. In some cases the hydrothecal and internodal walls collapsed in process of mounting for microscopic examination.

Loculity, etc.-Growing on a sponge, Port Stanley, Falkland Islands. 3rd February 1904.

Previous Localities.-Sonth of Tierro del Fuego and Island Pictou, Tierro del Fuego Archipelago.

\section{Plumularie pinnata, Linnæus, 1758.}

A number of colonies, the largest only abont $4 \mathrm{~cm}$. high, occur on sponges and on lamellibranch shells. The colonies agree with Hrxks's description. The following variations were noted in the specimens:-Generally the number of hydroclades per internode is two, but on a number of the distal internodes only one hydroclade occurs. The presence of a basal athecate internode at the origin of each hydroclade, as described by Billard (1904, p. 204), was noted, but between the thecate internodes no intermediate athecate internodes were observed.

Gonosome.-While the proximal, and therefore the older, gonangia assumed the spinous form figured by Hinks (1868, Pl. 65), the distal, younger gonangia were somewhat eup-like, with a truncated appearance, due to the inversion of the topmost portion of the gonangium, which, at first inverted, apparently becomes everted in the later stages of growth.

Locality, etc.-Growing on sponges and on lamellibranch shells, coaling jetty, Cape Town Docks. May 1904.

\section{Plumularia unilateralis, n. sp. (Pl. II. figs. 1, 1A, 1 B, 1C.)}

The specimens for which this species has been formed are small, areraging only $2 \mathrm{~cm}$. in height, with simple recurved stems divided by slanting nodes into regular internodes, in general $0.4 \mathrm{~mm}$. in length, but rather longer towards the base. From the 
middle of each internode there arises a single hydroclade. In no case has more than one hydroclade per internode been seen. The hydroclades, which are set on short processes of the stem internodes, lie alternately in two planes, these planes being so set forward that the hydroclades appear to arise from only one side of the stem. They leave the stem at acute angles $\left(30^{\circ}\right.$ to $\left.45^{\circ}\right)$, and are divided into equal internodes $0.25 \mathrm{~mm}$. long, each of which bears a hydrotheca-one small triangular athecate internode separating the first thecate internode from the stem process. In some cases secondary hydroclades are developed from the side of a hydroclade internode at the level of the base of the hydrotheca. No internodal septæ are present, but the internode bulges proximally to form a support for the hydrotheca. The hydrothec: are cup-shaped, moderately deep, even-rimmed, and for a short distance distally they are free from the internode. They are closely approximated, the margin of a hydrotheca being on a level with the succeeding node. Nematophores are absent from the stem, from the stem processes, and from the athecate internodes at the origin of the hydroclades, but one small, shovel-shaped nematotheca occurs in the median portion of the internode just below each hydrotheea, while in the angle between the hydroclade and the free rim of the hydrotheca is a median, unprotected sarcopore.

Gonosome.-Gonothecæ about $1 \mathrm{~mm}$. in length oceur in parallel rows along the stem, apparently arising on the inner side of the hydroclade-bearing processes. They are ovate, with somewhat flat tops, and are very shortly stalked. The gonothece are seldom smooth, the walls being generally strengthened by seven regular longitudinal ridges, which terminate distally in one or two more or less pronounced spines.

Locality, etc.-Growing on a sponge from the entrance to Saldanha Bay, Cape Colony ; 25 fathoms. Date, 21 st May 1904.

\section{Antennularia hartlaubi, n. sp. (Pl. III. fig. 4, 4A, 48.)}

Colonies growing on a sponge in thick bunches. with thick fascicled stems which, about $1 \mathrm{~cm}$. from the base, break up irregularly into smaller, still fascicled branches, these finally breaking up into long simple twigs. The latter are divided by straight nodes into regular internodes $0.5 \mathrm{~mm}$. long, each of which bears three equally distant hydroclades so arranged that those on one internode exactly alternate with those on the internodes above and below, a hexastichous arrangement thus being produced. The hyclroclades are borne on stout processes of the branch internodes $0.15 \mathrm{~mm}$. long, and are divided into unequal internodes which are alternately long and thecate and short and athecate - two athecate internodes separating the first thecate internode from the supporting process. Sometimes, however, two athecate internodes are developed between a hydrotheca-bearing pair. Each internode is marked by two strong internal septa, one proximal, the other distal; but in the longer internodes two more are sometimes developed, one opposite the base of the hydrotheca, the other a little lower. The hydrothecx are shallow, even-rimmed, resting on a broad ledge of the internode (ROY. SOC. EDIN. TRANS., VOL. XLV., 542.) 
and free for a short distance distally. The nematophores, of the usual trumpet-shaped type, have an internal septum which gives them a two-jointed appearance and are arranged as follows:- Three on each thecate internode, two lateral and distal, and reaching a considerable distance above the level of the hydrotheca margin, the other median and proximal and arising just above a slight bulge in the internode; one on each athecate internode, except where two such internodes are developed in succession, when the proximal one is unprotected; on the branches there are two lateral nematophores on the hydroclade-bearing process and one in the angle between this and the branch, but in the next highest internorle.

Gonosome.-Not observed.

Loculity, ete.-Entrance to Saldanha Bay, Cape Colony, in 25 fathoms. 21 st May 1904.

The present specimens approach in general structure $A$. decussata, Kirch. (1876, p. 55), A. johnstoni, Kirch. (1s76, p. 55), and A. irregulares, Quelch (1885, p. 8), for in the first and last of these the hydroclades, although generally two in number per internode, may vary from two to three or even four. In our specimens the hexastichous arrangement appears to be constant, and the species is distinguished from those mentioned above in having exceedingly strongly developed internodal septa.

We have named the above form after Professor CL. Hartladb of Heligoland, author of the report on the Belgian Antaretic Expedition hydroids, to whom we are inclebted for occasional assistance.

\section{Antennopsis scotia, n. sp. (Pl. III. figs. 3, 3A.)}

Two much weather-beaten colonies of a pale brownish colour, growing on a sponge fragment and reaching a height of $9 \mathrm{~cm}$. and $4 \mathrm{~cm}$. respectively. Both the colonies are badly weathered; the smaller is overgrown for half its length by the sponge, while the remaining portion is destitute of hydroclades. Here and there at irregular intervals a branch springs from the main stem, but without any definite arrangement. Of the larger specimen about $5 \mathrm{~cm}$. are free from the encircling sponge, and on this almost bare surface a few hydroclades occur. The stem and branches are strongly fascicled, about $2 \mathrm{~mm}$. in diameter, but the coenosare shows no signs of caniculation (Nuttixg, 1900, pp. 68 and 72). The hydroclades arise irregularly from all sides of the stem, springing from the outer tubes of the fascicle. Proximally they have from three to six athecate internodes separated by straight noles, the distal of these, and sometimes that beneath it, being greatly elongated and bearing a number of nematophores varying from two per joint to five on a single long internode. Above this athecate portion the hydroclade is divided by alternate slanting and straight nodes into fairly regular internodes, every alternate one of which bears a hydrotheca. The hydrothecx are stoutly campanulate and large, $0.22 \mathrm{~mm}$. in length by 0.22 to $0.25 \mathrm{~mm}$. in greatest diameter, with entire rim and oblique opening, adnate up to the distal end of their own internode, and afterwards free-the free portion lying over against the intermediate internode, the rim reaching the level of the proximal end of the next hydrotheca- 
bearing internode. They are thus closely approximated. The nematophores have a widely expanded, trumpet-shaped mouth, and besides those already mentioned, there are three on each hydrotheca-bearing internode, one median and proximal, standing on a slight angle of the internodal perisare, two lateral, each borne on a process which rests against the side of the hydrotheca. Only one nematophore oceurs on each intermediate internode.

Gonosome.-Not observed.

Locality, ete.-Dredged at the entrance of Saldanha Bay, Cape Colony, in 25 fathoms. Date, 21 st May 1904.

The general architecture approaches that of Antennopsis fascicularis (Allmax, 1883 , p. 24), but there are differences in the proximity of the lydrothecæ and in the number and distribution of the nematophores.

We have named this species after the Scotia-the ship of the Scottish National Antarctic Expedition.

\section{LIST OF LITERATURE CITED.}

ALDER, 1856. Annals and Magazine of Natural History.

" 1857. "A Catalogue of the Zoophytes of Torthumberland and Durham," in Trans. Tyneside Naturalists' Field Club.

Allman, 1\&76. Ann. and Maj. of Nat. Hist., th ser., vol, xvii.

" 1883. "Report on the Plumularians of the Challenyer Expedition," Sc. Reports, Zool, vol. vii.

" 1888. "Report on the Hydroids of the Challenger Expedition," Part II., Sc. Reports, Zool., vol. xxiii.

BuLlard, 1904. "Contributions à l'étude des hydröides," in Annales des Sc. Nat., vol. xx.

Boxxevie, 1899. The Hydroida of the Norvegian North-Atlantic Expedition 1876-78. Christiania, 1899.

Hartlaub, 1900. "Revision der Sertularella-Arten," in Abh. naturvo. Ver. Hamburg, vol, xri.

" 1904. "Hydroiden," in Résultats du voyage du S.Y. "Belgica" en 1897-99.

" 1905. "Die Hydroiden der magalhaensischen Region und chilenischen Kïste," in Fauna Chilensis-Supplement VI. to the Zoologische Jahrbücher.

Hisks, 1861. "A Catalogue of the Zoophytes of Devon and Cornwall," in Ann. and May. of Nat. Hist., vol. xi.

" 1868. A History of the British Hydroid Zoophytes.

Johnstone, 1847. A Hist. of the Brit. Zoophytes, 2nd ed.

Kirchenpader, 1872. "Ueber die Hydroidenfamilie Plumularilæ," Part I. Aglaophenia.

" 1876. Ibirl., Part II. Plumularia u. Nemertesia, in Abh. naturw. Ver. Hamburg, vol, vi.

," 1884. "Nordische Arten und Gattungen von Sertulariden," ibid., vol. viii.

LAMARK, 1836. Hist. Nat. des unimaux sans vertèbres, 2nd ed. Histoire des Polypes, Paris.

Lamouroux, 1821. Exposition méthodique des genres de l'ordre des polypiers, Paris.

Lisweus, 1758. Systema Naturce, ed. 10.

Nurting, 1900. "American Hydroids," Part I. Plumularidæ, in Spec. Bulletin Smithsonian Institute.

, 1904. Ilid., Part II. Sertularidæ, ibid.

Ortuas, 1896. Grundziuge der marinen Thiergeographie, Jena.

Pallas, 1766. Elenchus Zoophytorum, Hague.

Qtelcu, 1 $8>5$. Annals ant Mag. of Wat. Hist., ser. v. vol, xvi.

SARs, 1846. Fauna Littoralis Norveyix, vol. i. 
Ritchie. "Scotia." Hydroids. - Plate I.
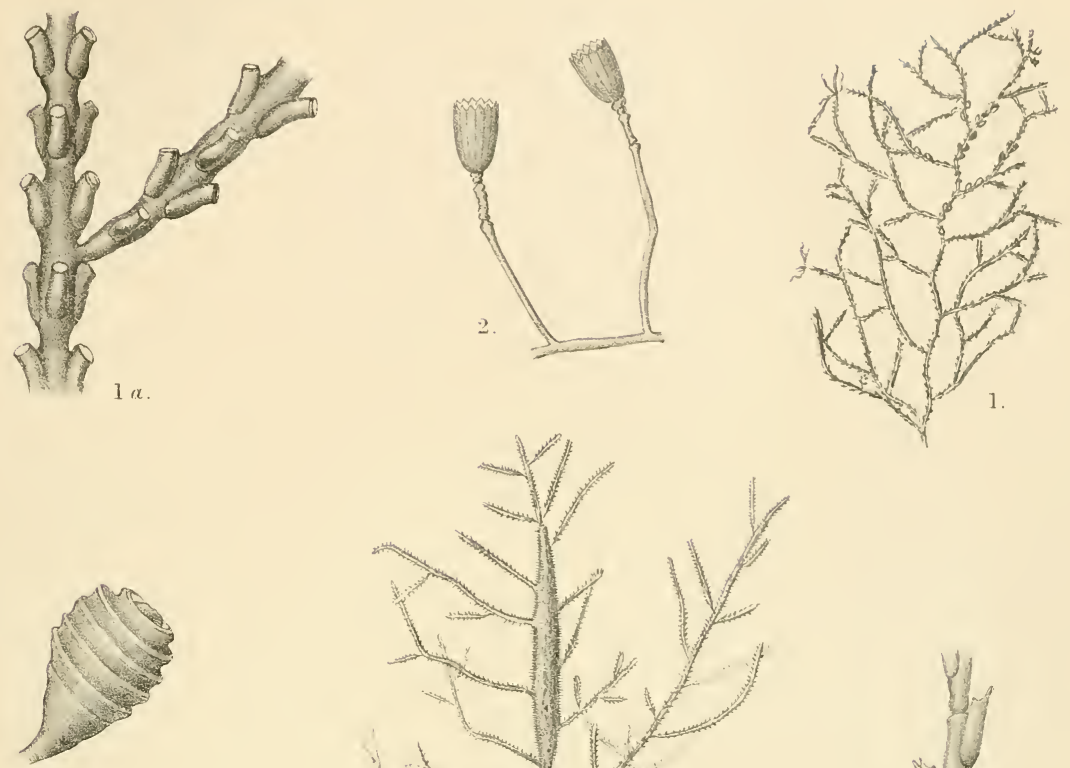

6.
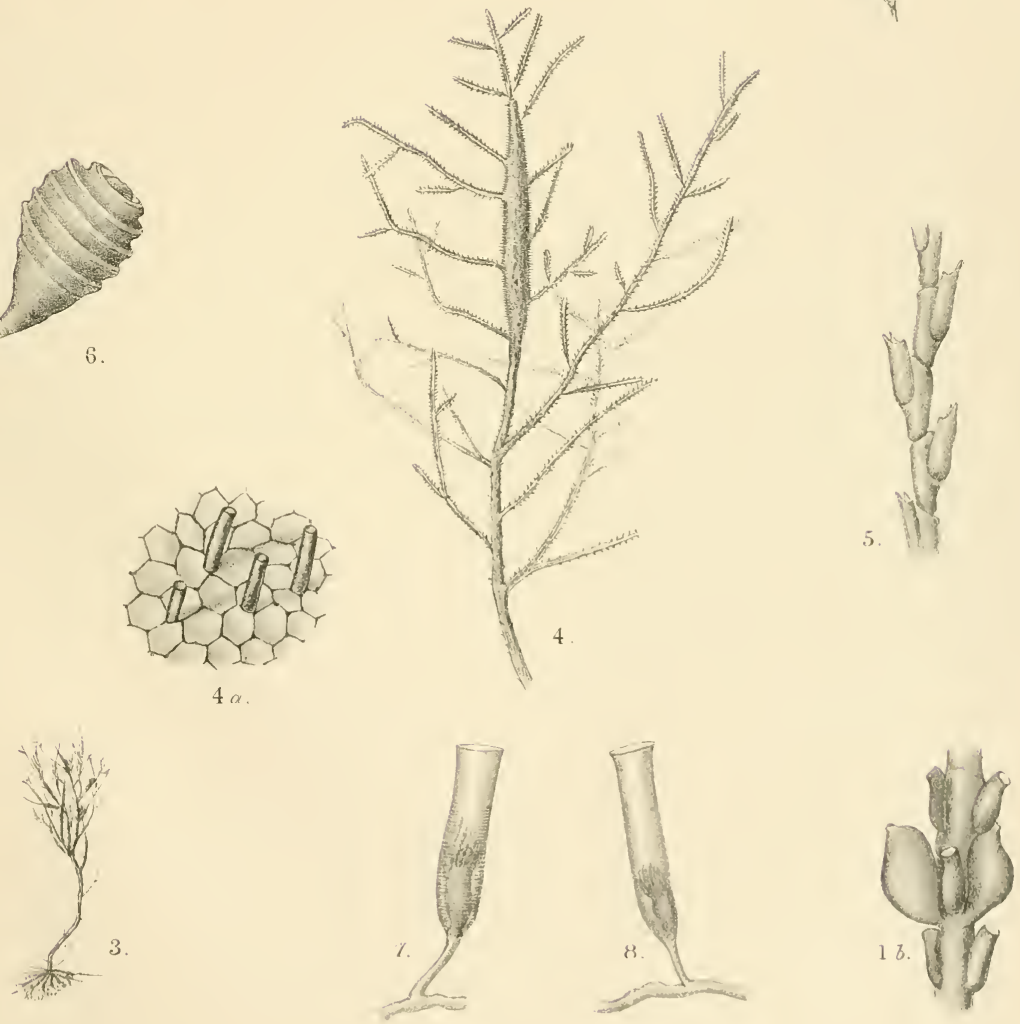



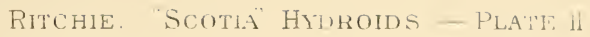
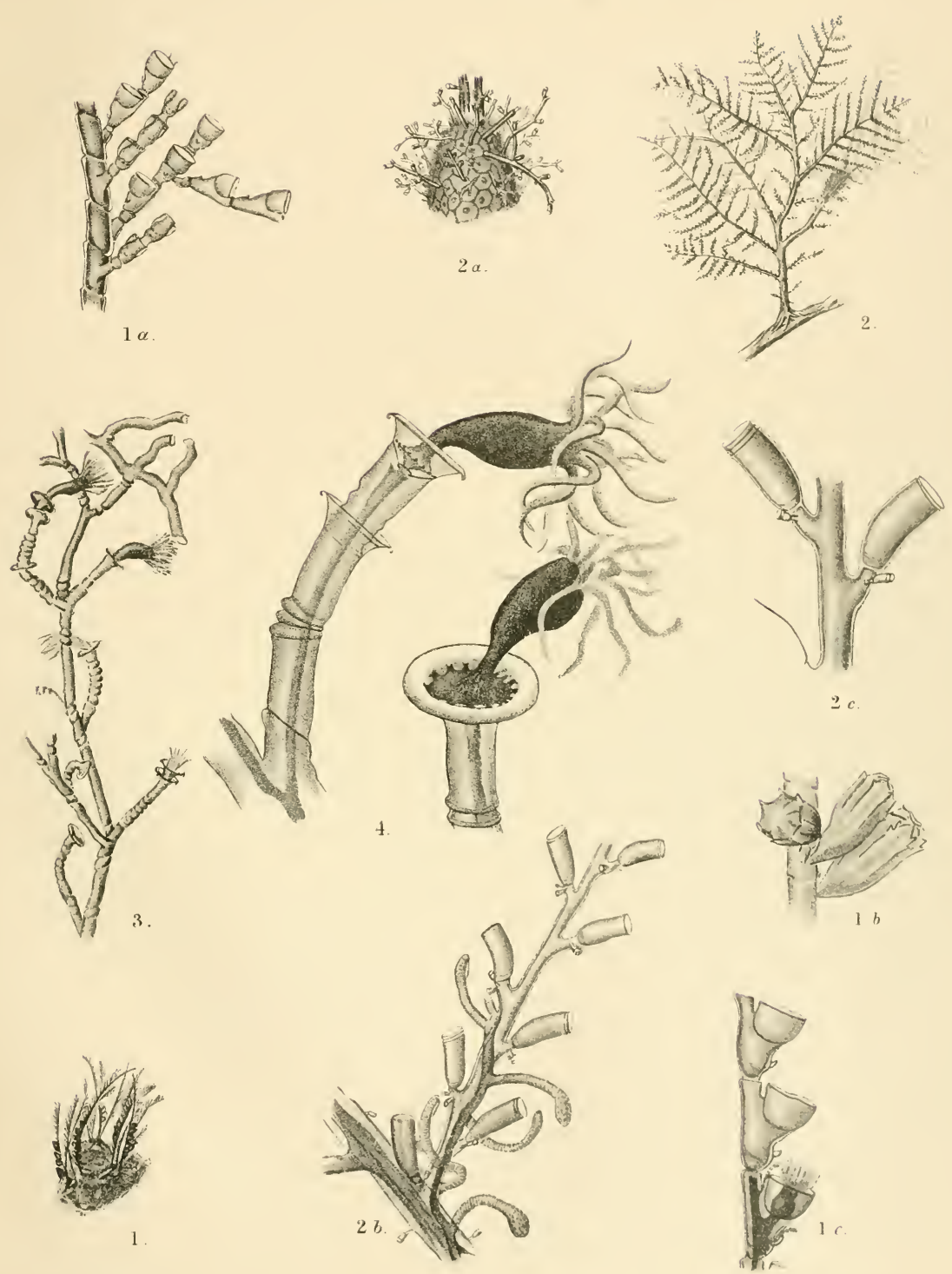

$2 c$
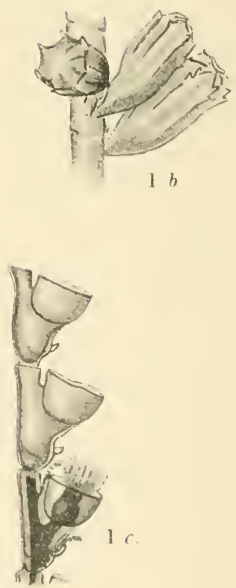

Trans. Roy. Soc. Edirr.

Vol. ILT:

RITChiE: "Scotia" HIDRUids - Plate lil.
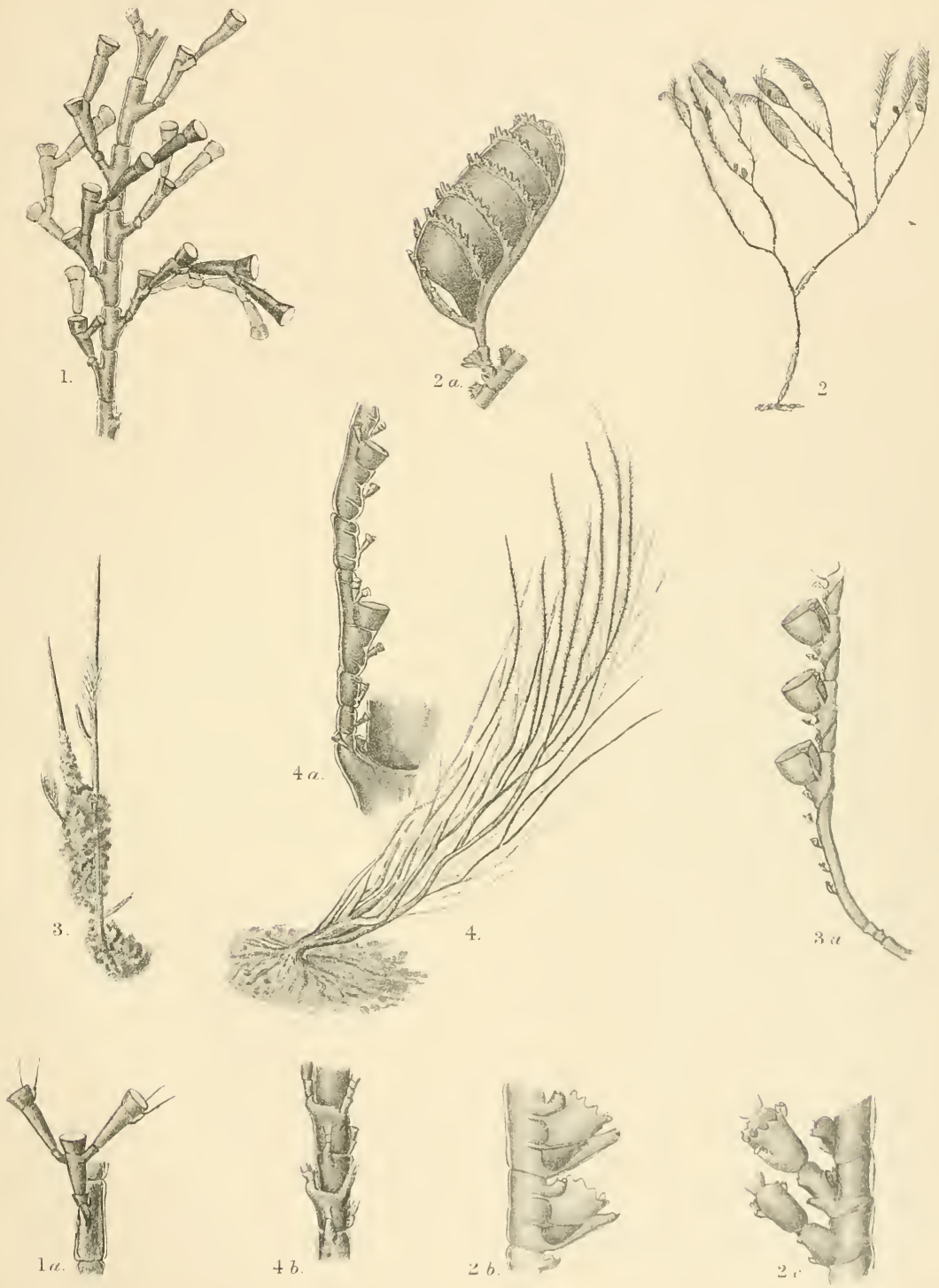



\section{EXPLANATION OF PLATES.}

\section{Plate I.}

1. Staurotheca reticulata, n. sp.

$1 \mathrm{~A}$.

1 B.

2. Campanulariu, sp.

3. Halecium interpolatum, n. sp.

$4 \mathrm{~A}$.

5. Sertularella rectitheca, $\mathrm{n}$. sp.

6. Ssynthecium robustum, Nutt.

7. Heliella striata, Allm.

8. $\quad$ var. plana, n. var.
Nat. size.

Portion of stem and branch showing hexastichous and decussate arrangements of hydrothecæ.

Portion of branch with gonangia.

Nat. size.

Nat. size, showing gonosome cluster.

Surface of gonosome cluster.

Gonangium.

Hydrotheca not completely ringet.

l'late 11.

1. Plumularia unilateralis, $\mathrm{n}, \mathrm{sp}$.

1 .

IB.

Ic. ", ,

2. Brucella armata, n. gen, et sp.

$2 \mathrm{~A}$.

$2 \mathrm{~B}$.

$2 c$.

3. Halerium interpolutum, n. sp.

4. Halecium tenellum, Hinks.

1. Plumulariu mayellanica, Hart.

1. ", ,"

2. Agluophenia dichotoma (Johns.).

$2 \mathrm{~A}$.

2 B.

$2 \mathrm{C}$,

3. Antennopsis scotix, 11. sp.

$3 \mathrm{~A}$

4. Antenularia hartlaubi, n. sp.

$4 . \mathrm{A}$.

t13.
,

,
Nat. size, growing upon a sponge fragment.

Stem with hydroclades.

Gonangia.

Portion of hydroclade with hydrothece.

Xat. size, showing coppinia cluster.

Surface of coppinia cluster.

Portions of a fascicled and an unfascicled branch, with a creepins polyzoon-Anguinaria spatulata.

Hydrothece.

Branch, with hydrothecæ, ending in stolons.

Showing attacliment of hydranth within hydrotheca.

\section{Plate III.}

Origin of a double hydroclade.

Nitt, size.

Corbula.

Hydrothecæ.

Portion of stem, showing origin of hydroclades.

Nat, size, partially encircled by a sponge.

IIrdroclade with hydrothece.

Nat. size.

Hydroclade with hydrothece.

Sitem showing hexastichous arrangement of hyylroclaules. 
II. Note on Primnoa reseda from the Faroe Channel, and on its Embryos. By Prolessor J. ARTHuR THomson, M.A. [With Two Plates.]

(Read 26th November 1906.)

A remarkably fine specimen of Primnoa reseda, Pallas, which used to be called the sea-mignonette, was obtained from the Froe Channel (from a depth of 355 metres) in June of this year by the "Goldseeker," one of the vessels engaged in the International Exploration of the North Sea. Through the courtesy of Professor I' Arcy W. Thompson, C.B., I was able to see the splendid specimen a few days after captnre, when the vessel came into port, and he has also given me permission to make this short note. The species-the only representative of the genus Primnoahas long been known, but an examination of the beautiful specimen in its fresh state has revealed some new facts of interest, e.g., as to the colour and the mode of reproduction. As one of the most gorgeous animals within the British area, it deserves some re-description in English, and a better figure than it has hitherto obtained.

The specimen was brought to the surface with its axis canght in a cleft in one of the boards of the trawl, and though withont basal attachment, it was otherwise almost undamaged. It is almost a yard in leeight ( 34 inches), and its branches spread out for 16 inches. It far surpasses the specimen in the British Museum.

The axis, where bared at the base, has a diameter of $\frac{7}{16}$ ths of an inch, and the average breadth of the branches, including the covering of polyp-calyces, is s.ths of an inch. The colour of the colony, which soon began to fade, was a brilliant salmon-pink-a fact which I have not found mentioned in any of the descriptions. Some fragments which I preserved are now creamy white. The bare part of the axis at the base was a fine greenish-bronze, with a metallic lustre. In a class famons for beantiful representatives, Primnoa resed" must be accorded a high place, alike for its graceful branching and for its richness of colonring, not to speak of the elegance of the individual campanulate polyps. In its fresh 
state it was one of the most beautiful animals I have ever seen.

My study of Primnoa reseda has been rewarded by the discovery of the interesting fact that the species is viviparous, and I have included at the end of the paper some notes on the embryos.

By way of contrasting the "Goldseeker" specimen with others previously obtained, I may briefly refer to a few of the old descriptions.

Linné (1728) called it Gorgonia lepadifera, and summed it up in the expressive words, "floribus sparsis consertis reflexis campanulatis imbricatis." He compared the polyp-calyces to barnacles, and noted that they were shut in by eight valves. He spoke of the cortex as albidus, but this seems to be only the post-mortem colour.

Pallas (1766) called it Gorgonia reseda, and gave a good description, alluding, for instance, to the resemblance between the close-set, recurved calyces and the fruits of mignonette, and to the branches thicker than swan's quills. He also speaks of the colour of the cortex and calyx-scales as white, whereas it is a vivid salmon-pink in the fresh specimen. He gives its locality as "mare norvegicum et forte indicum," but the snggestion of the Indian Ocean was probably due to some mistake.

In 1786 Ellis and Solander described it as "the barnaclebearing Gorgon" (Gorgonia lepadifera), and noted the dichotomous branching, the bell-shaped, scale-covered calyces, the minute whitish scales coverin the flesh, and the bone-like axis. The size is given as usually 18 inches high (contrast the 34 iuches of our specimen); the locality is stated as the coast of Norway, bnt the specimen figured came from Archangel. Attention is directed to the eight valves covering the mouth, which are compared to the scales on the head of the horned asp, Coluber cerastes. "In this Gorgonia, which is a fixt animal, the scales on the stem and branches, which do not move, are much of one form, differing greatly from those on the heads, which are always in motion, while the animal is alive and catching its food." The downward bent heads and mouths are compared to "some species of barnacles," 
just as others had compared them to fruits of mignouette (cf. Clusius, "Planta marina Reseda facie"). The two figures given by Ellis and Solander are fairly good.

Esper (1794) devoted about eiglit pages to the "sea-acorn horny coral," realising that it occupied a position by itself. But he was entirely mistaken in his interpretation of the animal, imagining that he had to do with an axis like that of Antipathes, on which little creatures related to barnacles had settled down! Yet his description, partly based on those of Gunnerus and Baster, is very accurate, and, as his work is somewhat inaccessible, I may be allowed to make a few extracts in free translatiou. The barnacle-bearing Gorgon is confined to Norwegian coasts, and does not occur in Icelandic waters; a height of 6 to 8 inches is common, but a large specimen was $2 \frac{1}{2}$ feet high; most of the branches are truncate, but some taper; the colour of the fresh axis is greenish, but it soon becomes brown; the axis is horny and stony, and covered by fine longitudinal lines; there may be forty-eight campanulate shells or "houses" on an inch; the colour when fresh is yellow, but it soon becomes dirty white; in most cases the mouths of the houses were towards the tips of the branches, but a few were turned in the reverse direction, and some were quiteawry; the houses are formed of rows of imbricating brittle scales, with 6-8 parts making a lid; but the houses do not really belong to the coral, for while it is related to Gorgonia antipathes, they are related to barnacles (Lepas).

It was Lamouroux who first recognised the essential peculiarities of this type, separated it from Gorgonians, and established the genus Primnoa.

In the Edinburgh Ncw Philosophical Journal for 1847, Charles Stokes wrote as follows:-"Primnoa lepadifera is found, I believe, only on the coast of Norway. I have specimens nearly 2 feet in height, which were presented to me by Sir Arthur de Capell Brooke, Bart., who collected them there in 1820. He received accounts of their growing to a much larger size. They are found at great depths, varying from 150 to 300 fathoms. At these depths they grow in company with a large branching Alcyonium of a red 
colour (A. arborea)." The latter is now named Paragorgia arborea.

He goes on to say that "the polype cells of Primnoa are membranaceous and covered with calcareous scales, ... these scales do not cover the whole surface of the cells; on the inner side, next to the stem, there is a part devoid of scales, as if, being less exposed, their protection was not needed. ... The substance of the cells being membranaceous, they are movable in all directions, as is shown by the different positions in which the cells of $P$. lcpadifera have dried, and bence a mistake was made by Ellis, who described the cells as 'reflexed,' that is, with the mouth downwards, which must have arisen from the position in which his specimens had been hung up to dry, as the weight of the cells would make them fall."

As the "Goldseeker" specimen was, naturally enough, not "hung up to dry," it may be interesting to note that while the great majority of the polyps were reflexed, a few among them had the mouth pointing upwards. They are so stiffly encased in scales that one finds it difficult to believe that they could possibly turn upon their bases of insertion. It is surely a growth-variation.

In his brief paper, Stokes refers to his figures of a Primnoa rossii, n. sp., which Sir James Clark Ross had obtained from a great depth (see his Voyage to the Southern and Antarctic Regions, vol. i. p. 334). This new species seems to have been left undescribed, but Dr J. Versluys notes in his splendid monograph ou the Siboga Primnoidæ that it was perhaps the same as Gray's Hookerella pulchella, which was also left practically undescribed. A specimen in the British Museum, labelled Hookerella, seemed to Versluys to agree closely with bis Thouarclla tydemani, but a comparison of the polyps was not made. Thus, so far as we know, Primnoa reseda remains the only species of its genus.

In 1861 E. Grube described "a new coral"-Lithoprimnoa arctica-from the Norwegian coast, in $70^{\circ} \mathrm{N}$. lat. This is, again, Primnoa reseda, Pallas. I have not been able to consult Grube's somewhat inaccessible paper, but there is a notice of it in the Annals and Magazine of Natural History 
for 1863 , p. 166. He describes the axis as greyish-white, whereas it was greenish-bronze in our specimen; he speaks of the concentric layers of lime amid the black cornein; and says that the calcareous scales on the bodies of the polyps and the eight oral valvules approximate it to Primnoa lepadifer $\alpha$, with which it is indeed identical.

It is interesting to notice that Verrill found Primnoa reseda in deep waters at $\mathrm{St}$ George's Bank in the Bay of Fundy. In the description which he gave in 1866, there are several points which disagree with what our specimen shows. He says: "Trunk large, arborescent, branching in a dichotomous manner, often very thick and stony near the base; branchlets round, tapering to slender flexible points; cells large, campanulate, irregularly scattered." But in our specimen the branching is only irregularly dichotomous, the branches do not taper to slender points, and the cells, though not in whorls or spirals, are closely crowded, and cannot be spoken of as scattered. Verrill also says that "the cells are capable of moving in different directions, but in preserved specimens are generally turned downwards." As already noted, we cannot believe in much mobility of the polypcalyces.

Gray's description also leaves a good deal to be desired. He refers to "the large basins or cups of the shape of hent reeds, membranous on the concave side, on the convex side covered with large imbricated overlapping scales. At the mouth of the cup the scales form a ring, and are eight in number, within which, in the retracted polypes, there is a coniform outstanding lid, which is forned out of eight long flat scales. Besides, the polypes at the base of the branches possess eight rows of suall calcareous bodies (spicula), and indeed, small out-pressed double clubs, covered with small warts and spines, approaching to simple spicules." $\mathrm{He}$ defined the species as "a coral alternately branched, diffused; bark with crowded, callous, recurved calyces."

In his diagnosis of the genus Primnoa, Gray says: "Coral branched, tree-like; branches cylindrical, forked. bark formed of scales. Polypiferous cells ovate, clavate, dependent, covered with two series of large convex imbricate 
scales, placed in whorls of three round the branches." But they are characteristically not in whorls in $P$. reseda, the only known species. The aperture, he says, is closed with three pointed scales, yet he himself points out that $P$. reseda has eight. "The axis is horny [really very calcareous as well], black [really burnished green-bronze], solid, cylindrical, the base being often covered with a hard calcareous longitudinally striated outer coat."

In his monograph on the Primnoide- a model of thorough and thoughtful workmanship-Dr J. Versluys abstains from a re-description of Primnoa reseda, because it is so readily recognisable. He gives the following diagnosis:"The polyps may be closely apposed to the twigs, as in Caligorgia, by their almost naked adaxial surface; only two abaxial rows of sclerites are well developed. At the upper margin of the calyx there are eight sclerites, each of which bears an opercular scale, and of these, as of the sclerites which bear them, the four adaxials are distinctly smaller than the four abaxials." "The branching is irregularly dichotomous, and relatively sparse. The colony spreads out, predominantly but not exclusively in one plane. The polyps are not in verticils, but are disposed irregularly and somewhat densely ; they are not in spirals."

Geographical Distribution.-Versluys sums up the distribution of Primnoa reseda as: North Atlantic, coasts of Scotland, Shetland Islands, Norway, White Sea, and on the American coast at St George's Bank, Bay of Fundy. Stokes says off Norway; and the British Museum specimen, presented by Dr Carruthers, is from the same region. The specimen described and figured by Ellis, presented to him by Solander, came from Archangel. Gray notes North Sea; Setubal (Prof. E. P. Wright); England (Johnson). In his British Animals Fleming notes, "This species, which is common on the Norwegian coast, has been found, according to Professor Jameson (Wernerian Memoirs, vol. i. p. 560), at Zetland and Aberdeenshire." We have now to add, Færoe Channel.

Embryos,-As I have mentioned, my study of Primnoa reseda has been rewarded by the discovery that this species 
is viviparous. Another form must therefore be added to the growing list of Alcyonarians in which viviparity has been demonstrated (see Thomson and Henderson in the list of References).

Many of the polyps in the fragments at my disposal were found to be crowded with embryos, but most of them were unfortunately at the same stage of development. As we have very few data in regard to the development of Alcyonarians, except the memoirs of G. von Koch, Wilson, Kowalevsky and Marion, and Lacaze-Duthiers, the following notes may be of service.

Attached to the mesenteric bands there were elongated clusters of ova at different stages of ripeness. Some of these were seen to have a very definite envelope, from which a stalk rau to the mesentery. Other larger egg-like bodies were lying freely in the colenteron. An examination of these showed that they were already well advanced in development, that they were, in fact, diploblastic embryos. Most were spherical or slightly ovoid, and some showed an invagination at one pole. A few were solid, most showed a well-developed cœlenteron. The following measurements of the diameter or of the longer axis were taken :- $-0 \cdot 4,0 \cdot 5,0 \cdot 6$, $0.7,0.8 \mathrm{~mm}$. In many cases the wall was about $0.1 \mathrm{~mm}$. in thickness, of which about four-fifths was due to the inner layer.

The ectoderm consisted of a single layer of columnar cells, sometimes with large vacuoles; the endoderm cousisted of a dense mass of small cells, in the middle of which there was usually a large ccelenteron. In most of the sections the endoderm appeared like a syncytium, and about half a dozen nuclei lay on every radial line across the wall one chose to follow. A very distinct double-contoured middle-lamella or mesoglœal plate lay, like a double basal membrane, between the ectoderm and the endoderm.

It seems, therefore, that we have to do with planule, very clearly differentiated into two layers, the immer of which is several cells thick. It is probable that the colenteron is formed by histolysis in the middle of the endodermic mass. There was no trace of typical gastrula. It is likely that the invagination or dimple seen in many cases at oue pole is the 
beginning of the stomodæum. Only in one section was there a bint of a blind stomodæal insinking insinuating itself into the colenteron, but the appearance was not sufficiently definite to be convincing.

Apart from the embryos, I have found little that is new to report, but I thought it might be both useful and interesting to gather together some of the references to this very beautiful northern Alcyonarian, and to submit these to a Society which has been for so long a repository for observations on the Scottish Famna.

\section{REFEREXCES.}

1728. Linve, Systema Nature, vol. xii. p. 1289.

1766. Pallas, Elenchus Zoophytorum, p. 201 (Gorgonia reseda).

1786. Ellis and Solayder, Natural History of Zoophytes, p. 84, pl. xiii. figs. 1 and 2 (Gorgonia lepadifera).

1794. Esper, Pflanzenthiere, part ii. pp. 7(1-78, pl. xviii.

1847. C. Sтокеs, Edinbuirgh Vew Philosophical Journal, vol. xliii. pp. 258-262.

1861. E. GRuBE [Deseription of a New Coral (Lithoprimnoa arctica) and Remarks upon its Systematic Position], Abh. Schles. Ges. vaterl. Cultur. (Abth. Naturw. u. Med.), p. 165, ef. Ann. Wat. Hist, vol. xii. (1863) pp. 166-7.

1866 A. E. Verrill, Mem. Boston Soc. Nat. Hist., vol. i. p. 9.

1870. Gray, Catalogue Lithophytes, p. 44.

1883. Wilsov, E. B., Development of Renilla, Phil. Trans,, vol. clxxiv. p. 723 .

1883. Kowalevsky et Marion, Documents pour l'histoire embryogénique des Alcyonaires, Mem. Mus. Marseille, vol. i. Mém. 4.

1887. Koch, G. von, Die Gorgoniden des Golfes von Neapel.

1900. Lacaze-Duthiers, H. DE, Coralliaires du Golfe du Lion, Arch. Zool. Exper., 3rd series, vol. viii. pp. 353-456.

1906. J. Versuuxs, Die Gorgoniden der Siboga Expedition, II. Die Primnoidre, pp. 84, 85.

1906. J. Arthur Thomson and W. D. Hexperson, Lebendiggebärende Arten von Alcyonaceen, Zoologischer Anzeiger, vol. xxx., No. 16 .

Reference to Plates.

Plate I. Photograph of the Colony.

Plate II. A Twig in Natural Size and Colour. 


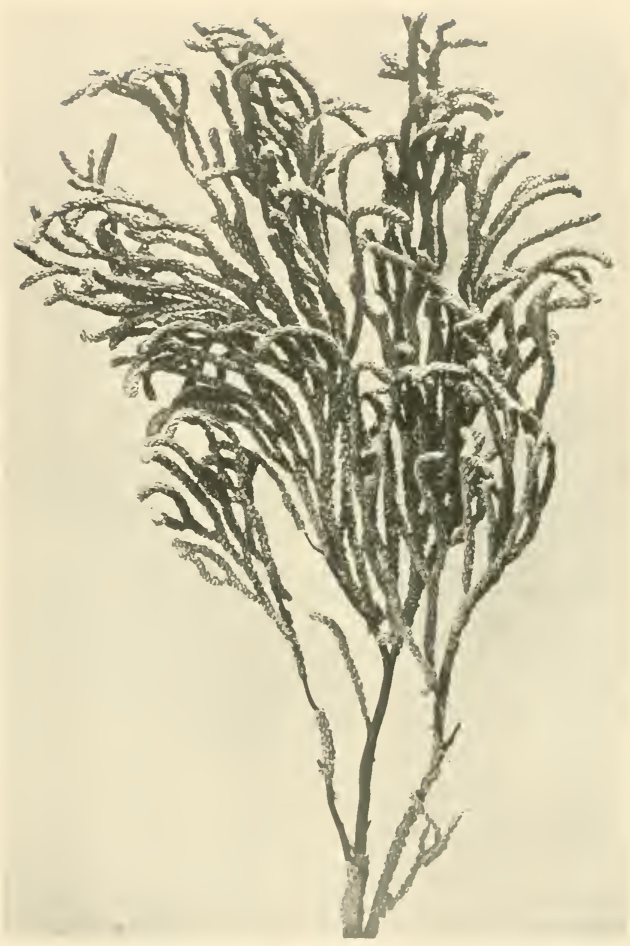

P1:1MNO.1 1:1-1.11A 

. 


$$
1
$$


V. On the Occurrence of a Supposed Australasian Hydroid (Sertularia elongata) in the North Sea. By JAMES Ritchie, M.A., B.Sc., University of Aberdeen. [Plate III.]

(Read 28th January 1907.)

In November 1904, Mr J. J. Simpson, M.A., B.Sc., while searching for chance specimens in the nets of the trawlers lying at Aberdeen Fish Market, came upon a magnificent cluster of Hydroid colonies, which he kindly handed to me for identification.

The colonies, of which there were about forty-five in the bunch, are fixed upon a slender twig, $0.2 \mathrm{~mm}$. in diameter aud $11 \mathrm{~cm}$. in length, which is in many places encrusted by Polyzoa. They vary cousiderably in size, the largest about $8 \mathrm{~cm}$. in height and $1.5 \mathrm{~cm}$. in breadth, the smallest about $2 \mathrm{~cm}$. by $0.45 \mathrm{~cm}$. When Mr Simpson found the specimens, the cœnosare had already wholly disappeared. Both the hydrocaulus and the gonothecæ (which are numerous, some of the colonies bearing a gonotheca on almost every pinna) agree specifically with the descriptions and figures of Sertularia elongata, Lamx., given by Prof. D'Arcy W. 
Thompson (1879), by Bale (1884), and by Allman (1885). Our specimens do not show more than three pairs of hydrothecx on any one internode, while Bale records that four or even five pairs occasionally occur, nor are there present branches of other than the regular pinnate order. But in these respects our specimens agree with those of Prof. D'Arcy W. Thompson, C.B., to whom I am indebted for the opportunity of examining his fine collection.

As to the knowu distribution of Sertularia elongata, so far as we can learn, it has been recorded from the sonth coast of Australia, where Bale (1884) says it is one of the most common species, more particularly from Cape Wilson, Port Philip, etc., in Victoria (Dr F. Müller, cited by Thompson, 1879); from Tasmania (Allman, 1885), particularly from Georgetown and Bass's Straits (Dr Harvey, cited by Thompson, 1879); from West Australia (Allman, 1885); from New Zealand, where the species is less common than in Australia (Gray, 1843; Huttou, 1872; Coughtrey, 1874), particularly from Lyall Bay, Wellington (Farquhar, 1895), and Kuri and Taieri beaches, Otago (Hilgendorf, 1897). That is to say, the distribution is limited to Southern Australasia. The West Australian locality of Allman is of special interest because, while our specimens differ in detail from his Tasmanian examples, they agree absolutely with the West Australian form in all the points which he singles out as peculiar to it.

The trawler in whose net the present specimens were found had been trawling off the Shetland Isles, and, on the return journey to Aberdeen, off Buchan Ness, the last haul having been taken in the neighbourhood of the "Buchan Deep." Consequently, the presumption is that the specimen found in the trawl-net came, if not from the last haul in the "Buchan Deep," at least from some locality in the North Sea. It remains to account for the presence of a species, so distinct and with so limited a distribution, in the North Sea. Three possibilities suggest themselves-(1) that the species grows in the North Sea; (2) that the specimen was brought thither attached to the bottom of a ship, as Tubularia crocea, Agassiz, was, in 1895, brought from Peru to Plymouth Sound 
(Browne, 1899); (3) that the specimen has drifted thither from its Australasiau locality.

The twig to which the colonies are attached helps to a conclusion. Cross and longitudinal sections are characteristic, showing a central strand of sclerenchyma surrounded by loose lacunar tissue, which again is surrounded by a thick band of sclerenchyma. The twig and sections were shown to Prof. J. W. H. Trail, M.D., F.R.S., to whom I am indebted for kind assistance, and he pronounced the branching and microscopic structures to be those characteristic of the marine phanerogams of the subfamily Cymodoceex in the family Potamogetonaceæ. This subfamily contaius but nine species, all of them, with one exception, belonging to tropical or south temperate seas, the majority occurring in West Indian, Indo-Pacific, and Australian waters (Engler and Prantl, 1889). The exception, the only north temperate form (Plucagrost is major), occurs in the Mediterranean Sea and along the Spanish and African coasts, but its structures are quite distinct from those of the present specimen, and it may therefore be left out of consideration. If, then, it is assumed that the North Sea Hydroid specimen grew upon the plant in situ, and it is the habit of Sertularia elongata to grow upon seaweeds (vide Bale, Allmau, etc.), the twig may be taken as indicating a tropical or south temperate origin for the specimen.

Since so conspicuous a Hydroid has not beeu recorded by any of mauy careful workers, and has not been found in many recent dredgings, from the North Sea, and since it has grown upon an exotic plant, the first supposition, that the species grows in the North Sea, may be rejected. The second supposition is also rendered impossible, because the very fact that the specimens have grown upon a twig excludes the possibility of their having been attached to a ship's bottom and thus transported. The conclusion remains, and it is indicated by the knowu distribution of Sertularia elongata, as well as by the characters of the twig to which the specimens are attached, that the North sea specimeu has drifted, probably from an Australasian, perhaps from a West Australian, locality to the spot where it was picked up. 
The ocean currents are not inconsistent with that view. While a specimen from South Australia would tend to drift towards New Zealand, a specimen set free upon the west coast of Australia (and the minutiæ of the present specimens agree with those of West Australian specimens) might be borne by an Indian Ocean south equatorial current round Cape Colony, whence, caught up by a north-travelling branch of the Antarctic drift, it might be carried into an Atlantic south equatorial current moving north-westwards into the Gulf of Mexico, and thence the Gulf Stream drift might bear it to the waters of the North Sea.

The journey is a long one-it has probably left its traces in the empty perisare and the polyzoon-encrusted twig-and the chances against its successful completion are many, but it seems the only satisfactory way of accounting for the interesting occurrence of so distinct a Hydroid species off the Scottish coast.

The suggestion has been wade that the specimen may have been taken accidentally, along with packing or ballast, on board some ship loading at an Australasian port, and was afterwards set free on the discharge of the ballast in the neighbourhood of Aberdeen. Such a mode of transport, however, involves so many coincidences of place that it seems highly improbable; and, besides, the condition of the specimen itself argues against the supposition, for it is difficult to believe that a number of large and fragile colonies could be first cast upon a rough sandy or shingly shore (suitable for ballast), and afterwards tossed about amongst ballast at loading and unloading, without suffering a considerable amount of damage. And yet in the present case, as the accompanying photographic reproduction (Plate III.) very clearly shows, almost all the colonies are complete, with naturally terminated stems and perfect pinnæ, upon practically every one of which, in the more mature colonies, are perched exceedingly delicate, loosely attached gonangia. The perfection of structures so fragile excludes the possibility of carriage by methods other than the most gentle, but is such as we might expect in a water-borne specimen, the sport of gently flowing oceanic currents. 
After all, the mode of transport from Australasian waters to the North Sea matters little, and does not affect the main purposes of this notice, namely, to record its occurrence and to show that the species in question, although it has been found in, is not indigenous to, British waters.

\section{REFERENCH.}

Allyan, 1885. Australian, Cape, and other Hydroids, in Journal Limn. Soc. Lortd.-Zool., vol. xix.

BALE, 1854. Catalogue of Australian Hyclroid \%oophytes, Australian Museum, sydney.

Bale, 1888. On some New and hare Hydroida in the Australian Museum Collection, Proc, Linn. Soc. 1. S:. W'ules (Ser. 2), vel. iii.

Blainvila, $1834-37$. Manuel d'Aetinologie, Paris.

Browne, 1899. On Trubularia crocea in ['lymouth sound, Jour. of . Murine Biolog. Assoc. of the Imited Kingrlon, vol. v. (N.A.), $1 \times 97-99$.

Covghtкея, 1874. Notes on New Zealand Hydroidex in Trans. Yer Keralaul Institute, vol. vii.

Congntrey, 1875. Critieal Notes on the New Kealand Hydroida, ibid., vol. viii.

Covgnтку, 1876. Critical Notes on New Zealand Hydroidea -Subnder Theeaphora, Ann. Mag. Sat. /list. (4), vol, xvii.

Engler and Prante, 1889. l)ie natürlichen Pflanzenfamilien, II. Tiel, 1-3, Leiprig.

Farquinar, 1895. List of New Zealand Hydroida, Trous. Fer Zealunel Institute, vol. xxviii.

Gray, 1843. Additional Padiated Animals and Anuelides in Dieffenbach's Travels in New Kealand, vol, ii.

HartuadB, 1905. 1) He Hydroiden der magalhansischer liegion und chilenisehen Kuste, in Zool. Juhrtucher, suppl. vi., vol. iii., 1905.

Hilaexnorf, 1897. (In the Hydroids of the Neighbourloud of Dunedin, Truns, Lew Kealund Institute, vol. xxx.

Hutgon, lise. On the New Kealand sertularians, Trans. Fex Zeulanel Institute, vol. v.

Lamovroux, 1816. Histoire Polypes Flex.

Lamovkoux, $1 \times 24$ (as joint-author). Encyclop. Méthodique.

Marktanver-Turneratscher, 1890). Die Hydroiden des $k$. $k$. naturh. Hofmuseums, Ann, naturh. Ilofmes. Hin., vol. s: 
Thompson, D'Arcy W., 1879. New and Rare Hyd. Zooph. from Australia and New Zealand, Ann. Mag. Nat. Hist. (5), vol. iii.

\section{Explanation of Plate.}

Colonies of Scrtularia elongata picked up in the North Sea (slightly reduced).

The central thicker and whiter rod is the twig over which the hydrorbiza of the colonies ramify, the whiteness being due to an encrusting polyzoon layer. 



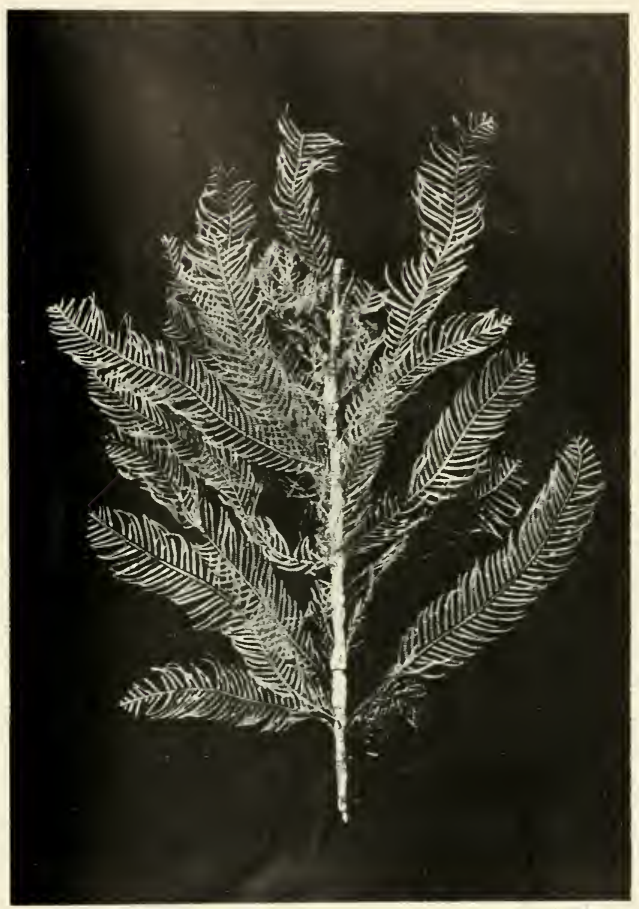

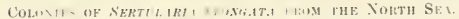


[Fiom the Proceedisgis of the Zuological Society of Londos, 1907$.

[Published October 8, 190 $\overline{7}$.] 
( ) collections of the Cape Verde Islands Marine Fauna. made by Cyril Crossland, M.A. (Cantab.), B.Se. (Loml.), F.Z.S., of St. Andrews University, July to September, I:94.* - The Hydroids. By Jimes Ritchis, I.A., B.se., Fullerton Scholar, University of Aberdeent.

(Plates XXIII.-XXV1. $\ddagger$ and Text-figures 142-144.)

The forms describel in the present paper were entrusted to me for determination by $M[x$. Crossland, who collected them in various localities off the Cape Verde Islands. Although the collection is not a lirge one, it forms a useful addition to our rather meagre knowledge of the Hyilroil fama of the northern portion of the west coast of Afriea. To the north of the Cape Terde Islancls srecimens lave been recorded from the Canary Islands, from Maleira, from the Azores, and from the Soulan const; from the south the 'Challenger' recorls a solitary species, Cryptolaria diffusa Allm. from Sierra Leone; while from the islands thenselves, so far as I ran learn, records have been made by only four workers $\$$. In 1683 Allman, in his Report on the Plumularians cullected by the 'Challenger,' describerl the type of a new genus. streptocaulus pulcherrimus Allm.. found at Porto Praya in 100 fatlioms. In July 1885 Mr. J.J. Quelch described a small collection of deep-sea Hydroitls, comprising nine species, and obtainer from the cable off $\mathrm{st}$. Vincent in a depth of over 500 fathoms, the species described being Eudendrium annulatum Yorman lstit, Lafoëe tenellula Allman 1877, Zyyophylax profind Queleh 1885, I'lumularia variabilis Quelch 1885, P. delicatula Qnelch 18x5, Autennularia irregularis Queleh 1885, A. motunda Quelch 18x5, Aglaophenia acacia Allman 1883, and Streptocaulus pulcherrimus Allman 1883. More recently Professor J. Versluys has ileseril ed two species from Isle Branco, one of the Windwarl Group, Sertularia (1)esmoscyphus) brexicyathus (Vers. 1899), and Desmoscyphus inflatus Vers. 1899, a synonym for the D. yracitis of Allman $] \times 88$, which has been renamed Sertularia versheysi ly Professor Nutting (1904). Of these the latter oceurs in our collection, with the important addition that the gonosome is also present and is here described for the first time. Lastly, within the past month or two collections made by the "Talisman' in $1 \times-3$ have been described by Dr: Armand Billard (1907), and these include a few species from two localities off the Islands. In lat.

* The expenses of Mr. Crossland's collecting trip were borne by the Carnegrt Trustees.

+ Communicated by the SECRETARY.

\pm For explanation of the Plates, see p. 514

Since this paper was written I bave found in the collections made by the s.ottish National Autarctic Expedition on its homeward rosage two species trou st. Vincent which were not rejuresented among the specimens described in the Report on the 'Scotis' Hot represented among the specimens described in the crenata? Hartlanl, 1901, and Sertularella fusiformis? Hincks, 1861, both of which are additions to the recorded Hydroid tauna ot the Islands.

488 
$17^{\circ} 1^{\prime} \mathrm{X}$. and long. $27^{\circ} 24^{\prime} \mathrm{W}$. (Paris $0^{\circ}$ ) at a dejth of 105 metres there were obtained Diphasia pinater (Ellis \& Sol. 17 $\$(6)$, in tenuularia ramosa Lamarek 1816, and Thecocarms myriophyllum var. bedoti Billard 1907 . In lat. $16^{\circ} 52^{\prime}-16^{\circ} 53^{\prime} \mathrm{N}$, and long. $27^{\circ} 30^{\prime}-27^{\circ} 26^{\prime} \mathrm{W}$. at a depth of $400-580$ metres, Diphasia pinaster and Thecocarpus myriophyll am bedoti were again found.

The present eollection is littoral, the greatest dejth at which specimens were gathered being 15 fathous, while the niajority were obtained in shore-pools or in quite shallow water. Hrace it is not surprising to find that of the species previously descriled from the Islands only one, Sertularia versluysis above inentionul, shoulk recur among IIr. Crossland's specinens.

The collection contrins in all 27 snecies, of which 18 our of them here represented by a new vaiety-have heen previously describerl. Several of these species, which are listributed anong 14 genera, have been recorled from more than one locality. For the remaining speeimens 9 new species have been establislied, one species being referred to a new genus. In all representatives of 20. genera oceur in the collection.

The list of species is as follows:-

\section{GYMNOBLASTEA.}

Family CORYXID.s. Coryne (?) dubium, sp. u.

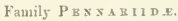

Pennerria cavolinii Ehrenbere 1532.

Family TCB C I A R IID $x$.

Tubularia hunilis Allman 186t.

"solitaria Warren 1906.

Family CLATI $x$.

Soleniopsis dendriformis, gen. et sp. n.

Family BotG

Hydractinia verdi, sp. 11 .

Polocoryne anchinata, sp. $\mathrm{n}$.

Family EtDEX DTID

Eudendriun ramostm Lim. $175 x$.

II. ALYPTOBLASTEA.

Family H A I ECIID F.

Itatecium beanfi Juhnot. 15.34.

Oplimles caciniformis, sp. $\mathrm{n}$.

Family LA F

Filellum serpens (Hassall 1852).

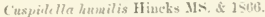

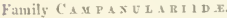

Clutid yeniculatu Thorndy 19ij.

Obelia dichotoma (Linn, 1758).

Gonothyree gracilis (Sars 1851).

C'ampenularia caliculata $\mathrm{H}$ isck- $1 \mathrm{SB}$.

" pitychecyatlines Alluwa 1884.

"nutulilis, sp. 11. 
Family SERTELABIID.

Sertularia distans Lamx. 1816.

, mayeri Nintting 1904.

" versluysi Nutting 1904.

, laevimarginata, sp. $\mathrm{n}$.

Family PLE I ULA R I I D $x$.

Plumularia halecinides Alder 1859.

Monostachas quadridens (McCrady 1857).

Aglaophenia marginata, sp. n.

Lytocarpus grandis, var. unilateralis, var. $\mathrm{n}$.

" crosslandi, sp. n.

Of the 18 hitherto known forms above mentioned, 10 are recogrised as British species, while 5 of the remainder (Campanularia ptychocyathus, Sertularia mayeri, S. versluysi, Lytocarpus grandis, Honostachas quadridens) are, with the exception of the last which has been recorder from the Indian Ocean (Thornely, 1904), distinctively American. This contingent is probably to be accounterl for by the oceanic whirlpool the centre of which is marked by the Sargasso Sea and the streams of which wash the shores of the West Indies, of eastern Mexico, and of the eastern Lnited States, and, circling in the North Atlantic, sweep past the Azores, Madeira, and the Cape Terde Islands.

The collection, as miglit be expected in a littoral one, is comparatively rich in grmnoblastic forms and includes an interesting species, peculiar in branching and in gonophore, which has been made the type of a new genus, Soleniopsis.

We note also, as Pictet has already remarked (Pictet, 1893), that of those species which occur both in temperate and in tropical waters, the individuals existing in the colder seas are, in general, larger and more sturdy than their tropical specific equivalents.

The outlines of the figures, both in the plates and in the text. with the exception of those representing the appearance of the specimens to the unaided eye, were drawn with the help of Zeiss's camera lucida.

The localities from which Mr. Crossland obtained his specimens are shown below:-

ST. VINCENT, CAPE Verde Islasds.

(1) GexERAL.

(a) From tidal pool, 25th July, 1904.

Pennaria cavolinii Ehr.

(b) 2 fathoms, amoug coral, 22nd July, 1904

Pennaria carolinii Elir.

Sertularia mayeri Nutt.

Plumularia halecioides Hinclis.

(c) 10 fathoms, 27 th July, 1904.

Gonothyraea gracilis Sars.

Companularia ptychocyalhus Allm.

(d) 15 fathoms, 30th July, 1904.

Monostachas quadridens (MeCrady). 
1907.

(e) From bottom of a liphter, 20th July, 1904.

Tulutaria hunilis Allin.

Cuspidella humilis Hincks.

Plumularia halecioides Alder.

Aglaophenia marginata, sp. $\mathrm{n}$.

(f) From bottom of a lighter, 30th July, 1904.

Peunaria cavolinii Elur.

Tubularia humilis Allin.

" solitariallarren.

Solenimpsis denlrifornis, gen. et kp. n.

Halecium beanii Johnst.

Filellum serpens (Hassall).

Cuspidella humilis Hincks.

Clytia geniculata Thorn.

Obelia dichotoma linn.

Campanularia ptychocyathus Allm.

$$
\text { " nutabilis, sp. n. }
$$

(2) Nattiota, St. Vincent Harbotr.

Sertularia lavimarginata, sp. n.

Lytocarpus crosslamili, sp. n.

(3) Porto Geavde.

(a) Shore-pools.

Campannlaria caliculata Hincks.

" ptychocyathus Allm.

Sertularia distans Lamx, 1816.

(b) 10 fathoms. mayeri Nutt.

Hydractinia verdi, sp. n.

pORTO PRAYA, Santiago, Cape Verde Islando.

(a) Piles of pier, 12th August, 190 .

Coryne (?) dubium, xp, 10.

Cantpanularia mutabilie, sp. n.

Sertularia versluysi Nutt.

(b) of fathoms, 9th August, 190) f.

Podocoryne ancchinata, sp. n.

(c) 10 fathoms, 12th August, 19.4.

Eudemlrium ramsusu Linn.

Ophiodes caciriformis, sp. $\mathrm{n}$.

BOA Vista, Cape Vegne lalaxid,

Soleniopsis dentriformis, gen. et sp. $\mathrm{n}$.

\section{GYMNOBLASTEA.}

Family C'OR Y XID.E.

('onjie (?) DLBic i, sp. n. (Plate XXIII. figs. 1, 2.)

A species represented by small, irregularly ramitiel culouits growing upon a Polysiphonia-like red seaweerl. The colonies are only about $7 \mathrm{~mm}$. in height. The perisare is transparent, tinged. 
excej, towards the tips of the branches, with a faint brown. The stem is slender, $0 \cdot 1 \mathrm{~mm}$. in diameter, and soon breaks up into very numerous, irregularly disposed branches which, arising at a small angle, lie for a short distance almost parallel with then parent shoot and thereafter gradually direrge from it. Branches even of the fourth order are present. The colonies are wrinkled throughout, but less strongly in the milllle portions of the polypbearing branches; while beneath the polyp, on the stems, and on the older portions of the branches distinct ringing occurs. There is no membranaceous eup surrounding the base of the hydranth. The hydranths are relatively long, $0.5 \mathrm{~mm}$., slightly bulging heneath and tapering gradually upwards towards the tip and ilownwarls to form a long "neck." The tentacles are from $0^{\circ} 1$ to $0.15 \mathrm{~mm}$, in length, and except for the distal four, which generally appear to be placed in a wlorl, are scattered. They vary slightly in number. Thus of 10 heals examined, one bore 12 tentacles, four bore 13 , three bore 14 , and on two 15 were found.

(ronosome not present.

Locality. Growing on a serweed taken from piles of pier: Purto Praya, Sintiago, Cape Verle Islands; 12 th August, 1904.

Owing to the absence of the gonosome this species cannot be given a definite generic place within the family Corrnidae as defined by Delage (1901). Notwithstanding I have assigned a specific name to the form in order to facilitate references. The trophosome characters lie between those of Actinogonium pusillum (Tan Beneilen 1844; Hincks, 1868, p. 45 ; Allman, 1872, p. 27.2) and syncoryne sarsii Lorén 1835 . From the former it differs in having a more tapering polyp, numerous rings and wrinkles, and in lacking a membranaceous cup beneath the polvp; from the latter it is distinguished by the shape of its hydranth, its much smaller size, its complicated branching, its wore frequent rings.

The specimens bear many creeping polyzoon colonies (clionella?) and occasional stalked protozoa and liatoms.

\section{Family PEXXARIID E.}

Pexxaria Catolixir Ehrenberg 1832.

A number of colonies, frequently orer $6 \mathrm{~cm}$. in leight, have been obtained from one locality. They agree in general with Allman's description (1872, p. 364), but the following variations may be noted :-The colonies are less robust than those described lv Allman. The branches, while alternate, lie generally in two planes, every other branch being in the same plane, and these planes are set forwarl on the stem, as in many Plumularian species, so as to meet at an angle varying from almost $180^{\circ}$ to less than $20^{\circ}$. Ringing is well marked, from four to six rings occurring on the stem above the origin of each branch, and a similar number at the base of the branch itself. Thus the ultimate hyitranth-bearing ramuli, instear of being wholly ringed as described and figured by Allman, tear a small number of basil 
rings; the remaimler, which varies much in length, being smooth or very slightly erumpled.

The gonosomes, which are present in numbers, ngree exactly with Allman's description.

The colonies here described agree in all but size with beantifully preserved specimens of the species from the Naples Biological Station.

Locality. St. Vincent, Cape Verde Islands. Obtained from buttom of a lighter, 30th July, 1904; by diving among coral in 2 fithoms of water, 22nd July, 1904; also fine colony in tirlil pool, 25th July, 1904.

\section{Family TCBULARIID.E.}

Toneciria Invmis Allman 1864.

A few simple or slightly branched stems varying from 0.5 to $4 \mathrm{~cm}$, in height, and $0.5 \mathrm{~mm}$. in diameter, may be referred to this species. The specimens obtained in one dredging are uuch smaller than those lescribed by Allman, varving from 5 to $12 \mathrm{~mm}$. in height; but the following points have been relicd on in identification: - simple or slightly branched stems with, here and there, faintly marked transserse rugosities; delicate, light-yellow perisarc; a conosareal collar supporting the liydranth; small hydranths, $1.2 \mathrm{~mm}$. in height, longer than boad, with, in the individuals examined, $17,13,11$ tentacles in the distal whorl, and $19,17 \mathrm{in}$ the proximal. The tentracles are in a state of contraction, and consequently the proximal whorl is only $1.8 \mathrm{~mm}$. in diameter from tip to tip.

Gomosome.-In the specimens obtained on the 30th of July gonophores are present in erect clusters borne on short pedicels. In some of the more mature, actinulae can be seen.

Locality. St. Vincent, Cinje Verde Islands. Found growing on the hottom of a ligrhter cn 20 th and 30 th July, 1904, and by diving among coral in 2 fathoms of water on 22 nd July, 1904.

Tubllaria solitaria Warren 1900.

A few solitary indivicluals, 8 mm. in height, are growing upon a sponge-like layer encrusting a small lamellibranch shell. The individuals are fixed in the layer hy a club-like, sometimes branched "root," and are erowned hy a distal circle of stout tentacles 13 or 14 in number, the lower portions of which are arlnate to the hypostome, appearing as strong riclges upon it. The proximal tentacles, which are more slender thin the distal, arise from the broadened base of the livdranth in a whorl of about 30 , rather more than in Jr. Warren's specimens. Otherwise, the present specimens, with delicate perisarc, distinct endodermal canals in the hydrocaulus, erect blastostyles originating just within the proximal whorl of tentacles aml bearing from two to five or six gonophores, agree with the description of the type.

The gonophores in our specimens are mostly at an early stage, 
showing in optical section a manubrium surrounded by a horseshoe-shaped mass of generative plasma. In only one gonophore of the many examined was there a trace of actinula-formation. tentacles being indicated by apparently about 8 filaments.

Locality St. Fincent, Cape Verde Islands. Found on bottom of a lighter, 30th July, 1904.

Previous record, off Natal coast.

\section{Family CLA VID E. \\ Solexiorsis *, gen. nov.}

Type, S. dendriformis, sp. n.

Gexeric characters. - Trophosome. Colonies branched and fuscicled. The branches originate from the division of a cuenosarcal strand into two portions which lie parallel and close to me another for a considerable distance, each becoming sheathed in a chitinous perisarcal tube, the outermost strand finally bends ontwards and becomes free to form a branch (vide text-fig. 142, p. 496). The hydranth-bearing ramuli originate in the same way as the branches. Hydranths cylindrical, with club-shaped proboscis and many seattered filiform tentacles.

fronosome.-The reproductive borlies are permanently fixel gonophores of a simple type. They are blind sacs arising from the conosarc some distance beneath the liydranth and lying within the perisarcal tube from which the lydranth projects. The ova are developerl in the wall of the sac.

The genus Soleniopsis is distinguisher by its peculiar mode of branching and by its gonophore. The branching, which is more fully described in the discussion on the species, appears to be similar to that of Corydendrium (Weismann, 1883). I have not seen the original description, but Dr. Fowler says with regard to the branching of the genus, "The young buids, instead of breaking through the perisare and growing outwards as is usual, grow upwarils for some distance inside it and surround themselves with secondary perisare" (Fowler, 1900, p. 13); and this agrees with the structure in the present genus. Corydendrinm differs from Soleniopsis, however, in having gonophores which give rise to free meduse (Delage, 1901).

The gonophores liere are of great length and of extremely simple structure. They are also peculiar in lying within, and thus heing protected by, the tube which contains the trophosome, instead of bursting through the perisare and forming hernia-like globular projections like most other gonophores. The ora and spermatozoa apparently escape from the mouth of the tulve, passing between the swollen bulb beneath the neck of the hylranth and the perisarcal wall.

On account of the seattered filiform tentacles on the hydranth

- The name of the genus, Soleniopsis, is intended to suggest the resemblance between the parallel-lying cuenosarcal strands of the colony and the "solenia " of Alcyonarians.

494 
and of the fixed gonophore, this genns lias lyeen included in lite family Clavisia, although the simplicity of the gonsphore and the complexity of the branching aluost wamant the formation of : new fimily.

Solexiorsis DEXDRIForMis, sp. n. (Plate XXV1, fig. 1; textfigs. 142, 143.)

The colonies for which this species lits been formerl weye fouma at two locenlities. The solitioy esolony from lion Vista is the largest of the series, slmost $10 \mathrm{~cm}$. high, with a thick, fiscicled stem which is, tewateds the hase, covereel by a mass of ramifying tuless, forming a spongy tissue through which here and there it hydranth pojects. This loosely built bitsal mass attains it cliameter of $1 \mathrm{~cm}$. From this stem, which in transoerse section shows a small central strand of chitiu with a few minute crenosarecontaining canals, smrounded by many panalled tubes which agaiu

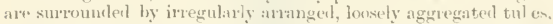
the branehes arise appoximately in one plane. The colonis. firom St. Vincent are sualler, only $(;$ en. high, and la $k$ the syongy basal thickening, possissing it erlindtical stem 2 mm, in diameter, composed of closely packed parallel tulses. From thene stems, as from that of the previous specimen, fonbelinte lnanches lying generally in one plane arise. The primary hranches lua ilternate seeondary bronches, and these again niay l ou tertiar. branches, all of these appearing to he fiscicled owing to tl.o apposition of several tubes. Fingle, monosiphonic branches, huil ever, arise alternately in one plane, for the most part fio.n branches of the second and third order, and from the distal end of these the hyilranths project.

The mode of branching is peeuliar. In the less strougly faseicled portions of the stem two or thee prisireal tules lie alongside of, and inseparably unitert tw, one ancther. each con

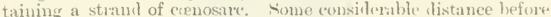
a liee huanch originates (frequently 20 or $311 \mathrm{~mm}$.) one of th outermost strands divides into two, and round the new ecpnosar, division a ditinons tulse is formed, wotged in hetween the ohl tules. Thus the number of frirallel-lying and united tubes is inereased, but finally, after a comse of sone 2 or 3 cen., the outermest of the two portions into which the originat strand divilest hecontes free to formi a branch, and the number of tubes in the

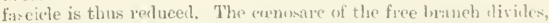
us dirl that of the stem, aud becomes chsheatheal in seremal miterl tubes which, on beming outwarls and heeoming free, form new branches or liychunth-bearing ramuli. The division of the (aries sareal strankls, and consequently the origin of the branches ant ramuli, takes place alternately; first on one sinle, then on the other.

The hydranths project from simple, alternate muli $0.4 \mathrm{~mm}$. in diameter. Extented they are long ami slencler, $2.0 \mathrm{~mm}$. ly 0.2 or $0.3 \mathrm{~mm}$, ahuost erlinilriel, with a pominent club-shape
Proc, Zuol. Soc, -1907 , No, XXX11. 
proboscis and short $(0.3 \mathrm{~mm}$.) stumpy tentacles. These, between 40 and 50 in number, are scattered over the body of the polyp, only the distal 4 or 5 being placed in a whorl, although an :tpproximation to whorling is sometimes simulaterl by others of the tentacles. At the proximal end of the hydranth there is a short neck, and just within the margin of the tube a sharp bulge connecting the polyp with the cenosarc of the ramulus and almost

Text-fig. 142.

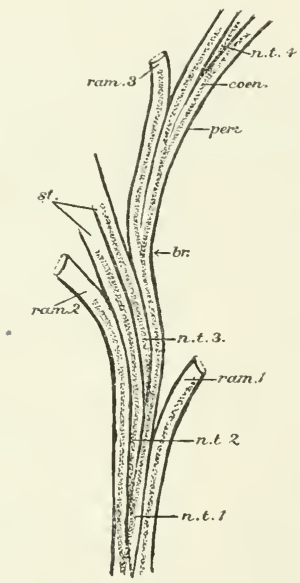

Soleniopsis dendriformis. To show mode of branching, $\times 9$

coen., ccenosarc; peri., perisarc; $b r$., branch bending off and becoming free from main stem; st., main stem; ram. 1, 2,3, short ramuli from which hydrantbs project; n.t. 1, 2, 3, 4, new tubes, enveloping a branch from a couosarcal strand and wedged in between older tubes.

jugging up the entrance to the tube. Contracted, the hydranths form almost spherical bulbs about $0.7 \mathrm{~mm}$. in diameter. Although the tube from which the hydranth springs generally ends abruptly with an even circular margin, in not a few cases the terminal 496 
portion is wrinkled and twisterl as if it were less strong, more collapsable than the other pritions.

Gonosome.-The gonophores are fixel, not developing into free medusoids, and lie within the tube from which the hydranth mojects. They branch off from the cenosare of the ramulus from 2 to $3 \mathrm{~mm}$. below the bydranth itself, and are long, slender, spindle-shaped bodies, sometimes $2.5 \mathrm{~mm}$. in length by $0.1 \mathrm{~mm}$.

Text-fig. 143.

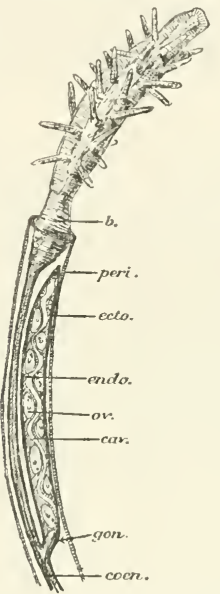

Soleniopsis dendriformis. II $y$ dranth and gonojhtore, $\times 30$.

$b$. bulging portion at hase of hydranth almost filling the opening of the tutu peri., perisarc; ecto., eetoderm, represented within the tube by a dark line cudo, endoderm (lined); ov., ovum; cav, central cavity of gonophore; gon., tho arrow points to the place where the gonophore branches off the general ewenowite ccen, general ecenosarc.

in diameter. Their structure is simple, the gonophore being apparently a hollow cylinder closel distally, with two-layerecl walls, a thick ectolerm and thinner endoderm, within which ova levelop to the number of about $13 \mathrm{or}$ more. The ova develop 
.tl along the walls. pushing the encloderm inwarls until it protrutes into the hollow of the gonophore. The male gonophores are simjlar in origin and shape to the female, but are in general considembly longer. In no case could a spadix be dist inguished.

The stricture of the gonophore ahore describerl is of the simplest type. It apperis to be merely a hlimb braneh of the general conosare of the colony within the walls of which ova lavelop.

Associnted with the specimens were sereral creeping Hrdroids, Filellum serpens. Cuspidella humilis. Campanularia mulabilis, and an endoproctan polyzoon (c'lionella?).

Localities. (a) St. Vincent, Caje Verle Islands: growing on the bott im of a lighter, 20th and 30th July, 1904.

(h) Drealged; Bu a Vistal, Cape Terde Islanik, August? 1904.

\section{Family BOtGAIXILLIID.E.}

Hrdractixia verdi, sp, n. (Plate XXI11, figs. 6 d 7 .)

Among drealgings taken at Porto frande four Fusus-like gastropod shells were obtained oversy real by Hylractinia colonits. The nutritive livilyanths, which grow in the groores of the shellsculpture. are in various stages of contraction, the longest $5 \mathrm{~mm}$., the short-st with their ring of tentacles ahnost rexting on the surface of the sluell. The tentacles are short, set in two almost indistinguishatle whorls, and var in number from 9 to 12 . 9 being perhaps most frequent. The hypostome is clnb-shayed. No spial filaments are present, although along the maryin of the shell there ocem elongated polyps with insiguificant tentacles. short chitinous spines, absut $(j \cdot 3 \mathrm{~mm}$. long, with jaggerl erlges, oceur thronghont the colony, being arrangerl for the most part upon the rilges of the shell. The blastostyles are somewhat sualler than the nutritive hylranths, being about $1 \mathrm{~mm}$, in height, but unlike those of $H$. echinata they bear well-dereloperl tentacles eight or nine in number. The basal rhizom expansion is thin.

Gonosome.-The reprouluctive boties are fixed gonophores arising from the body of the blastostyle some distance below the tentacles. They occur in a single wlort containing three or four individuals and are borne on short peduncles. In the specimen. examined the gonophores were all female, containing three large ora; whlle in the more mature examples these were separatel towards the exterior by pigmented bands ruming from the lase towarls the summit of the gonophore-branches of the spadix.

This species is closely related to $I$. pacifica described from (albuen by Hartlaub (1905, p. 519), but that speeies differs in possessing about 15 tentacles on the nutritive hydrantlis, only 5 or 6 on the blastostyles: in lacking spints on the basal expansion; in hearing only one orum in each gonoplore.

Locality. Porto Grande, St. Vincent, Cape Verde Islands; 10 fithoms.

$4: 8$ 
Ponocorine anechinata, sp. n. (Plite Xxili. figs. 8, 9, 10.)

Sparsely scattered u on a small gasteropor shell ('erithium? sp.) are the minute indivituals of a Porlocoryne colony. The nutritive individuals are club-shaped, only $0.9 \mathrm{~mm}$. in height, with a promineut, exlindrical, flat-topped hypostome, from beneath which arise about nine tentacles, set in two closely apmoximated whorls. Both spiral filaments and spines me absent. The reproluctive polyps, althongh they are somewhat smaller than the nutritive with ahout seven well-rlevelopert tentacles, resemble the latter in shape, being also club-like and possessing a prominent cylindrical hypostome. The bas:1 expansion is formel of a single laver of chitinous tubes, forming wille rectangular meshes, the indivictual tuhes being ahmost $0.1 \mathrm{~mm}$. in diameter, and being markerl laterally by minute honey-yeltow dots, thickenings of the chitinons wall. 'The whole expansion is covered hy a thin laver of comosajc.

fionosome. - The sexual stage consists of free-swimming medusoirls which arise in consiterable numbers (as many as nine being present on one individual) from the median portion of the reproductive polyp. They are borne on well-dlefinesl pertuncles, 1)uring the earlier stages the tentacles aprear as four blunt knobs, but these develop considerably ere the medusoil is set free. Suxual prorlucts could not be distinguished in the medusoid luds.

The species here deseribed is a near relative of $P$. humilis Hartlanb 1905. The latter form, however, diflers in possessing a minute conical hypostome, small smonth spines, and a medusoid hud which is not mentioner as develeping well formed tentacles ere it is set free. The difference in the number of tentacles is of little importance, although it is to be noted that here they form two closely-set wholls, but the chitinons thickenings which oceur along the siles of the rhizom strants (vide Pl. XXIII. fig. 10) may help to distinguish the prent species.

Locality. Porto Praya, Santiago, Cape Verde Lstamks, 5 fathoms; 9th August, 1904.

\section{Family EUDEXDRIID.F.}

\section{EtdexdrfuM ramosta Linneus 1758 .}

A single, small, unfasciclel colony alyout $4 \mathrm{em}$. high. The branches and branchlets are strictly alternate, anl the minute structure, except that the rings at the bases of the main branches are generally fewer in number, agrees elosely with II incks's figrues (1868. pl. 13). The hydranths are woll preserved and there were, in the examples counted, 23 or 24 tentacles suroumling a viry distinet trumpet-shaped liypostome.

Gonophores not present.

Loeality. Purto Praya, Aintiago, in fathoms; 12th August, 1904. 


\section{CALYPTOBLASTEA.}

Family HALECIIDE.

HaLecium Beavi Johnston 1838.

Several strongly fascicled, irregularly hranehed colonies. The delicate structure of the terminal branchlets is characteristic of the species. The branches differ from those in the specimen figured by Allman (1888, pl. xii. fig. $3 a$ ) in arising laterally from below a hydrothea, instead of directly from the branch. The majority of the primary hylrothecre differ from Allman's and from Hincks's (1868) figmes in being sessile and adnate to the node from which they arise-the hydrotheca-tier springing from within the primary hydrotheea; but in these respects they agree with specimens from the French coast described by Dr. A. Billard (1904, p. 163), and with specimens from dredgings made by the Scottish Antaretic Expredition at Burlwood Bank, near Caje Horn (Ritcliie, 1907).

The bright refringent points which encircle the base of the hydrotheca are in this species, as in others I have examined (1907, p. 515), points of attachment for strands from a fleshy dise at the base of the polyp, which is thus supported within its minute hyilrotheen.

The gonosome is ahsent in the present specimens.

Locality. St. Vincent, Cape Verle Islants, growing on the hot tom of a lighter; 30th July, 1904.

OpHiodes cacisiforms, sp, n. (Plate XXIII, figs, 11 \& 1 ? Plate XIIV. fig. 1; Plate XXV. fig. 5.)

sereral small, delierte colonies, for which this species has been formel, arise at irregular intervals from a hydrorhizal stolon creeping upon a fragment of a stul-corered worm-tube. They are neither brancherl nor fascicled, and the largest is but $6.5 \mathrm{~mm}$. in height. The stem is divided into short internodes, $0.4 \mathrm{~mm}$. long in the proximal, lut gradually lengthening to $0.6 \mathrm{~mm}$. in the upper part of the colony. The distal ead of each internote appears to divile into two equal, slightly diverging portions, one of which firms the perluncle of a hydrotbec, while the other bears the succeeding internole, the junction between the two internodes heing marked by a single annnlation.

The hylrothece lie in one plane, are placed one on each interworte, and are alternate. They are borne on perluneles of rarying length, from 0.05 to $0.2 \mathrm{~mm}$, the upper portions of which are delicate and frequently crumpled, while the bases are thick-walleil and, eren when the hyilrotheca itself has been destroyed, remain as projecting processes. The hrilrothecæ themselves are shallow, trumpet-shaped cups, with much-everted margins, delicato walls, aut in thin septum separating their carity from that of the stem. Around the wall just within the margin is a row of rafringrut points formed by slight thickenings of the perisare within the 
hydrotheca, and to these are attached strands supporting a flattenerl disc-like portion at the base of the polyp. Such an attuchment, of course, makes the pretraction of the polyp injossible. The structure is identical with that which I have alrealy described and fisured in the genus Halecium (Ritchie, 1907, 1. 525), except that in Malecium the basal disc rests upon the jerisarcal septum at the buttom of the eup, while here a consiclerable space intervenes hetween the two, traversed by a narrow strand of conosare connecting the prlyp with the conmon cenosarc of the eolony. I would draw attention to the seeming inaecuracy of Hincks's figures $(1868$, pl. 45 . figs. 2, 2) as regards the relations between polyp and hydrotleca. The liydranths, which are about $0.9 \mathrm{~mm}$, in height, gradually increase in dianeter ujwards from the basal dise, hut exhilit no distal contraction beneath the tentacles such as Hincks figures. The bases of the tentacles, which number ahout 23 , are connected $l, y$ a web within which the hypostome arises. A secondary hydrotheca, borne on a relatively long peduncle, may arise from the lower portion of the preduncle of a primary hydrotheca.

Tematophores occur frequently but irregularty. There is nsually one on a peduncle, and sometimes one on an internode. They are sessile, cup-slaped, with delicate walls and everted margin, within which there is commonly a row of refringent dots. To these, as in the hvilrothece, a lasal cuenosareal disc is attached. The sireostyles correspond to those figured ly Hincks (1868, 1l. 45), with thin walls bearing seattered cnidoblasts, and a glubular head where large number's of these oflcnsive and defensive cells are aggregated. When contracted, a sarcostyle measures about $0.4 \mathrm{~mm}$., while one which was extended mensured $2.0 \mathrm{~mm}$. The cnidoblasts are narrowly oval, $17 \mu$ by $3 \mu$, and each contains a thread $220 \mu$ long, armerl near the base with a whorl of four larbs in the form of a cross, distal to which are snialler harbs pointing towards the tip of the thread and placed in four longitudinal rows, each of which contains about nine gradually decreasing barbs (Plate XXV. fig. 5). The enidoblasts occur throughont almost the whole colony, but are particularly common on the basal lises of sarcostyle and polyp, and at the tips of the sarcostyles and of the tentacles.

Oecasionally solitary hydrothece and uematophores arise from the hydrortizal tube.

The gonosome is not present.

Laculity. Porto Praya, Santiago, 10 fathoms; 12th August, 1904.

$$
\text { Family LAFOEID.玉. }
$$

Filellia serpexs (Hassall 1852).

This species is represented by scanty specimens ereejing on a fragment of a Gymnoblast colony. In essential characters the specimens agree with Ilincks's description (1868), but they appear to be of less robust growtl, while the margins of the hyiliotliece 
are frequently marked by seseral "regeneration-lines," as in specimens from the North Sea in my possession.

The coppinia-gonosome is not present.

Loculity. Creeping on soleniopsis dendriformis, which was found. growing on the bottom of a lighter: St. Vincent, Cape Verle Islands; 30 th July, 1904.

C'rspidelia hemis Hincks MS. \& 1866.

Yinute hyllothece arising bere and there from a tubular stolon creeping apon Saleniopsis dendriformis. The hydrothecre are delicate and cylindrical, generally $0.2 \mathrm{~mm}$. in height by about 0.05 in diameter, although a rare specimen attained a height of $0.4 \mathrm{~mm}$. They show in many cases a tendency to contract slightly towarls the proximal end, while the distal end is crownerl by convergent opercular segments. They agree with Hincks's description and figures of the species.

Gonosome not known.

Loculity. (a) Creeping upon a polyzoon, which was obtained growing on the bottom of a lighter: St. Vincent, Cape Verile Islands; 20th July, 1904.-(b) Upon Soleniopsis dendriformis ; 30 th July, 1904.

\section{Family C A IS P I C L A R I I D I.}

\section{C'litia gexictlata Thornely 1904.}

Several small colonies, the largest rather under $1 \mathrm{~cm}$. in height, growing on a polyzoon. The specimens agree in every respect with the original description and figmes, the peculiar methol of branching heing particularly noticeable. The hyllothece, which are some $1.1 \mathrm{~mm}$. long by $0.6 \mathrm{~mm}$. in greatest diameter, bar from 18 to 20 long teeth; each tooth being strengthened by a metlian fold which is continued for a short distance down the wall of the byihrotheca as a more or less definite line.

The gonangia rary somewhat as regarts their opening, sometime, having a plain, cylindrical, distal end; at other times with a distinctly constricted neck below the aperture. Sometimes they arise in pairs from the base of a perlicel.

Locality. Growing on polyzea found on the bottom of a ligliter ; a single specimen on the back of a small crab. St. Tincent, Cape Verde Islands; 30th Jnly, I904.

OBELA DICHOTOMA (Limmens 1758).

A few delicate colonies, the largest only $4 \mathrm{~mm}$. higb, occur on the carapace of a minute crab. The stems, which are unfasciclerl, are divicled by slanting nodes into regular internodes $0.4 \mathrm{~mm}$. in length, from the distal end of each of which arises a hydrotheca. Branches are frequent, sometimes $1.5 \mathrm{~mm}$. in length, arising in every case from the side of a pedicel. They are thus alternate, and, like the stem, they bear alternate hydrothecr, from the pedicels of which smaller branchlets with one hydrotheca may 
arise. Frequently the bramehes end in blind stolms. The liydrotheere are alternate and are horne at the distal ends of the internodes on short peilicels marked by four or five amnulations, the hase of the intermorle above that from which the perlical springs hearing a like number of rings. The ealycles are short and subtriangular, with a rather wile aperture and an almost even, delieate rim. The whote eolony is of delicate texture, the perisare being remarkably clear and hyaline.

Gonosome not present.

The form deseribed above seems to be a young stage of O. dichotome Limn. Its much smaller size, its lack of loorncolour, its branches arising from the side of a perlicel, and the shorter subtriangular shape of its hydrotheca, are differences insutfieient to distinguish it speeifieally from the oller form.

Locrelity. On the carapace of a small crab foumd crawling on the bottom of a lighter: St. Vineent, Cirpe Verde Islands; 30th July, 1904.

\section{Goxothy r.ea grachls (}

A few small specimens of this leatiful speeies oceur growing upon a fragment of eakareots material. The coloniss are only $8 \mathrm{~mm}$. in height, and difler from those dexcribed and figured by Ilincks $(186 x)$ in that the hyolnotheca are somewhat less slender: The remaning characters the peculiar origin of the branclues, stuck on, one would alnost think, as an alterthought, the gruclual tapering of the hychotheea towarls its lase, the number of the long pointed tectl, the ringing beneath the liydrotheea and at the proximal end of the lranches - agree with previous deseriptions.

Two long slender gonangia, with trices of a maginal collar as in 1 lineks's figures, are present, one arising from the hydrorbiza, the other from a pedineles.

Locality. Sit. Vincent, Cape V'arle Islands, 10 fathoms ; 27 th July, 1944 .

Campaxclata Calicthata 1lincks 1863.

Typieal examples of this speries, with erenter perdicel, dista spherical semment, and thick-watlerl, smooth rimmorl hydrotherap, oceur ereeping on a seawed. In our specinens the perlicels average $0.5 \mathrm{~mm}$, in length and are marked by about 10 crenations.

The gonangia are absent.

Locality. Porto (iramle: "retping on seaweed in a shore-prol.

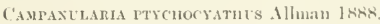

Numerous erowderl, pedumenlate hydrothere, anu gonangia springing from a creeping stolon have heen found on a prolyzoon. The specimens agree closety with Allman's dereription and figmes, especially chaxacteristic heing the delicate, frepuently collapsed, (iist:t portion of the hyllotheca, whieh in our specimens bears 10 long teeth; the stem with it few rings (grenerally two) beneath the hydrotheea and with several at the hase; the smooth 
cylindrical gonangia with marked constriction beneath the shallow saucer-like top.

From locality $c$ there are only a few hydrothece growing upon Siertularia distens, gonangia being absent.

Localities. (a) C'reening on a polyzoon found on the bottom of a lighter: St. Vincent, Cape Verde Islands; 30th Julv, 1904. - (b) On a pebble, 10 fathoms: St. Vincent; 27 th Julv, 1904. (c) Creeping on Scrtularia distans: Porto Grande, shore pools; ? July, 1904 .

Campanclaria mutarilis, sp. n. (Plate XXIII. figs, 3, 4, 5.)

Rare specimens occur creeping upon Sertuluria versluysi and Soleniopsis dendriformis. From a thick-walled, creeping, hydrorhizal tube the hydrothece arise at irregular intervals. They are borne on thick-walled peduncles with a length roughly threefourths that of the liydrotheca, varying from 0.4 to $0.8 \mathrm{~mm}$, and marked by from four to eight well-defined twists. The hvilrothece are large but vary from 0.8 to $1.2 \mathrm{~mm}$, in length and from about 0.5 to $0.6 \mathrm{~mm}$, in brearth. They are almost campanulate in shape, gradually widening upwarls to the margin, which is frequently oblique, is beantifully recurved, and is sometimes reduplicated (PI. XXIII. fig. 3). i slight ridge of perisare at the base of the hylrotheca forms a platform upon which a cunosareal disc at the bottom of the hydranth rests, and beneath this, seemingly within the peduncle, is a delicate basal septum. The hydrothece are seldom set symmetrically upon their peduncles. Owing to the state of preservation, the structure of the hydrantl could not be recognised. The tentacles appeared to be few in number.

Gonosone not known.

Localities. (a) St. Vincent, Cate Verde Islands: growing on specimens obtained from the buttom of a ligliter; 30th $\mathrm{Jul}_{\mathrm{y}}$, 1904.-(b) Piles of pier: Porto Prava; 12th August, 1904.

The specimens from Porto Praya (only a few hyllothecre have been found) are considerably larger than those from St. Vincent, but the specific structures in the two sets of specimens are identical ( $c f$. fig. 5 and figs, 3 \& 4 , Pl. XXIII.).

This species approaches Lafoea pocillum Hincks 1868. from which howerer it differs greatly in shape and in possessing an everterl margin. From Campanularia comugata Thornely 1904, it may be distinguished by its strongly-twisted peduncle, its campanulate shape, and its non-corrugated walls.

\section{Family S E R T C LARIID.E.}

Sertelaria distaxs * Lamoluoux 1:16.

A species represented by a few colonies growing upon a seaweed. 'The largest specimens are $7 \mathrm{~mm}$. high, while the internodes

* In accordance with the recent determination of Dr A Billard (1907), who has had an opportunity of examining the tspe specimen of Lamourous. I hate sulstituted the designation of that anthor for the more ustal synongm S. grosilis Hassall. 
average $0.4 \mathrm{~mm}$, in length. The hydrotheca are free for rather more than half their height distally, the free portion being sharply divergent. The margin is dividel into two lateral teeth, and there are two opercular flaps. The specimens agree elosely with the descriptions and figures of Hincks (1868) and Nutting (1904).

Gonangia not present.

Locality. Porto Grande: shore-pools ; ? July 1904.

\section{Sertularia mavert Nitting 1904.}

Several speeimens of this species have been obtained. The speeimens agree in all respects with the deseription given by Nutting, except that in our forms, which are smaller than the American speeimens - the maximum being ahout $7 \mathrm{~mm}$.- the liydrothece appear to be rather more elosely approximated, the length of an internode being only $0.6 \mathrm{~mm}$. While in many eases the margin and operculum had collapserl, as described by Nutting, in others this portion of the hydrotheca retained its form, and two large lateral teeth, with sometimes a minnte merlian superior tooth, and a two-llapped opereulum could be distinguished.

Gonosome not known.

Localities. (a) Porto Giande, St. Vincent, (ape Vrrde Islands: creeping on seaweed found in shore pools.-(b) On seaweel found by diving among coral in 2 fathoms of water: St. Vincent, $22 \mathrm{nd}$ July, 1904.

Sertulara versulxsi Nutting 1904. (= Desmoscyphus gracilis Allman 1888.) (Plate XXIV. figs. 2, 3, 4, 5, 6, \& text-fig. 144.)

A large number of colonies varying from 2 to $4 \mathrm{em}$. in lieight. The stem is erect, unfascicled, ani springs from a sprealing mass of hydrorhiza. The lower portion of the stem for a rlistance varying from 3 to $10 \mathrm{~mm}$. is surooth, thick-wallerl, and unhraneher and usually hears two straight internodes. The remainder, which is separated from the unlumehed portion by a long, sloping, splice-like joint, is dividerl by slanting noles into regular internodes about $0.7 \mathrm{~mm}$. in length, each bearing three hydrothecatwo on one side, one on the other. From beneath the lower of the two hydrotheca: the branches arise. They are alout $4 \mathrm{~mm}$ long, are regularly alternate, thus giving the eolony a plumose appeasance, and are dividerl into internodes, $0.4 \mathrm{~mm}$. long. ly nodes wlich slope from behind forward and downward. They are placed slightly on the front of the stem, and are borme on a long stem-process, hut arise at an angle of $60^{\circ}$ rather than at right angles as deseribed by Nutting.

The hydrothece are placed on the front of stem and branches on the former they are alternate and apart, while on the latter they are opposite, and contingent for the greater part of theil length, the distal free portion heing hent at right angles to the adnate portion. The liydrotheca pairs are distant from one another about the height of a bydrotliera. The hydrothece, short 
and stout proximally, gradually narrow towarls the opening, which is furnished with two long, thick-rimmed, lateral teeth. The operculum is composed of two flaps, in this agreeing with Nintting's description and differing from that of Versluys (1899, p. 43), where only a single flap is mentioned.

Gonosome.-The gonangia, which are characteristic, have not been previously described. They are $1 \mathrm{~mm}$. high, borne on short stalks on the front of the stem, generally one on each internorle. and arise from near the base of a hydrotheca. They are strongly compressed from back to front, somewhat flask-shaped, with their greatest diameter $(0.6 \mathrm{~mm}$.) near the base aud gradually narrowing towards the top, where a slight neck is sumounted by a flattened thise bearing two long, incurver, horn-like spines. These are placed, one on each side, immediately above the longitudinal lateral ridge formed by the compression of the gonangium. The gonangia are strongly ridged throughout, the ridges varying in number from five to eight. The gonangial contents eseape through a longitudinal shit with toothed edges, stretching along the flattenerl top of the gonangium from "horn" to "horu."

Text-fig. 144.

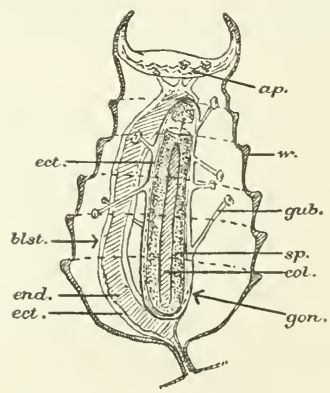

IIale Gonosome of Sertutaria verstursi.

a , aperture with toothed lips through which gonangial contents escape; $v$, wal of gonangium; gub., gubernaculum; $s p$., spermary ; col., central column of gonophore; gon., gonophore; ect., ectoderm; end., endoderm; blst., blastostyle.

A peculiar modification was noted in one of the specimens examined, where the distal and posterior portion of a branchinternode had become free and was prolonged into a straight 508 
sharp spine lying almost parallel to the continuation of the branch. The spiny appearance of the branch-bearing proecsses of the stem when denurled of their branches is also noteworthy (cf. Allman, 1888, p. 72).

Locality. Porto Praya, Cape Verde Islands: piles of pier; 12 th August, 1904.

Other localities:- Off Bermuda, 30 fathoms ('Challenger'); Cape Verde Islands, 25 metres (J'ersluys); on floating gulf-weei] ('Albatross'); N.W. of Cape Blanc (Soudan), in 55 to 60 metres (Billard, $190(i)$.

In the colonies examined, the gonophores were all male and in an advanced stage of derelopment. Their structures resemble those of Sertularia pumila as described by Nutting (1904. pp. 26 et seq.), but in most, owing perhaps to the advanced stage of the gonophore, the blastostyle is comparatively small, and in no case could be ohserverl to terminate in a thickenerl plug or "Deckenplatte." On the other hand, delicate strands of ectoder'm stretched from the outer coat of the gonophore to the gonangial wall, to which they were attrached, thus mooring the gonophore within the gonangium. Nutting, who also has found similar "gubernacula "in a male gonangium but arising from a sperm-bearing blastostyle instear of from a true gonophore, suggests that they may connect the ectoderm of the blastostyle, or in this case of the gonophore, with a delicate ectodermal layer which in some cases lines the iuside of the gonangial walls (Nutting, 1904, P. 24). In these specimens I have been unable to letect the presence of an ectodermic gonangial layer such as Nutting describes. He also suggests that they may possess the uutritive function attributed by Weismann (1883) to the guberuacula of "Sertuluric pecmila."

Sertularia levimargiNata, sp. n. (Plate XXVI. figs, 5 \& 6.)

Sereral minute colonies, less than $3 \mathrm{~mm}$. in height, spring from a creeping hydrorhizal tube which ramifies over a polyzoonencrusted frond. The stems are unfasciclerl and unbranched and are divided into distinet internodes, alout $0.3 \mathrm{~mm}$. long, which lecome much constricted in the neighbourhood of the nodes. The portion of the stem proximal to the first ristinct norle, which slopes at a high angle from back to front, is atlecate, lut ench internode bears two opposite hydrothece towards its distal end.

The hychrothece rest upon a bulging portion of the internole and are somewhat ventricose, the bulging portions meeting on the front of the stem, but leing slightly sejarated, for $0.01 \mathrm{~mm}$, behind. For less than half their height they are arhate to the stem, but the distal portion (about $0 \cdot 28 \mathrm{~mm}$. in length) bends sharply outwards, so that the apparent npper sides form an almost straight horizontal line. The free portion becomes gradually constricted and tube-like towark the margin, which is smooth and is characterised by a shallow sinus on its upper edge at the base of which is attached a disc-shaj ed adeauline operculum 
This opereulum is frequently drawn within the lyydrotheca. The aperture faces obliquely upwards.

The gonosome is absent.

Locality. Creeping upon a leaf found in one of the bottles containing Mr. Crossland's collection of tunicates from Mattiota, St. Vincent Harbour, Cape Verde Islands.

The peculiarly shaped hydrothece in the present specimen bear some resemblance to those of Sertularia lucernaria Kirchen. 1864 ; but in that species the aperture is almost horizontal, with a very distinct margin, the hydrothecæ are widely senarated, and the colonies are branched, with a bushy habit of growth, rltogether different from the minute, simple, and scattereil colonies of S. levimarginata.

\section{Family PLU HULAIIDE.}

Plumularia halecioides Alder 1859.

This species is represented by a few specimens, attaining a maximum height of $2.5 \mathrm{~cm}$., which agree closely with the deseription of Hincks (1868). The following variations from and arkditions to that description were noted:- The branches, which are rare and may arise on any side, spring in the specimens examined, not from the original hydroclade-bearing tube, but from one of the secondary tubes of the stem-fascicle; the hydroclades bear up to six hydrothece in place of IIincks's maximum of four; intermediate athecate internodes ase not always present between thecate internodes, thus in 100 initernodes examined only 31 were athecate and intermediate, a pair of the latter rarely occurring together; the gonangia, for the most part strongly ringed, occur not only on the stem but also on the liydrorhizal tubes. Similar variations have been noted by Billard (1904, pp. 181 et seq.) in specimens from the French coast and from Algeria.

Locality. St. Vincent, Cape Verde Islands: growing on the bottom of a lighter; 20th July, 1904. Also found on 22nil July, 1904, by diving among coral in a depth of 2 fathoms.

Moxostechas Quadridens (McClady 1857). (Plate XXV. fig. 4.)

Two colonies have been referred to this species. They differ markedly in size and habit from the flabellate, dichotomously hrancher, 6-inch high specimens described by Nutting (1900, p. 75); for they are unbranched and but $1 \mathrm{~cm}$. in height. Nevertheless the minute structure agrees so closely with Nutting's descriptions and figures, that I cannot regard these specimens as specifically distinet. I noted, however:-(1) The peculiar manner in which the hydroclades arise from the stem. The distal portion of the stem-internode bends over towards the anterior atspect of the stem, and to the end of this bent portion the hydroclade is attached by a slanting node; while from the posterior 508 
portion of the bend a second stem-internode arises, at an angle with the first. Each liylroclade lies in a line with the steminternode from which it arises, and from the posterior aspect of which the sncepeding stem-internode is thrown off at an angle (Pl. XXY. fig. 4). The structure of the colony thus comes to resemble that of a lielicoid eyme. (2) An unprotected sarcostyle, not mentioned by Nutting, issues from the angle between the liydrotheca and its internoite. The arrangement of the nematophores agrees with that in Nutting's figure, pl, xiii. fig. 2, except that the supracilycine nematophores more closely resemble those in fig. 4 , scarcely reaching the margin of the liydrotheca. On the stem-iuternodes, of which there are only four in our largest specimen, the nematophores vary from 3 to 5 .

Gonosome not present.

Locality. St. Tincent, Cape Verde Islands, 15 fathoms: 30th July, 1904.

In the collections made hy Professor W. A. Herdman, F.R.S., in connection with the Gulf of Manar Pearl Fisheries Investigations, small specimens of this species vecur similar in size to those above described- "half an inch is the height of the largest colony" (Thornely, 1904, p. 120).

Aglaopuexia margixata, sp. n. (Plate XXIV. figs. 7, 8, 9, 10.)

Slender, monosiphonic colonies reaching a height of $6 \mathrm{~cm}$. The normal condition of the colonies is simple, for in only one specimen was a branch found, springing from the anterior surface of the stem. The stem is diviled into internoles, $0.5 \mathrm{~mm}$. in length, each bearing a hyctroclade on a prominent, romded and perforated process lying inilway hetween the nodes. The hylroclades are short, generally less than $3 \mathrm{~mm}$., set forwarl on the stem, alternate, and divicled into internorles $0.35 \mathrm{~mm}$. long, each of which bears a hylrotheca. Two internodal septa are present, one proximal and opposite the intrathecal septum and exteuling completely around the internorlal wall; the other distal and less pronounced, opposite the base of the stupracalycine nematophores, ant sloping slightly upwaris.

The hyllothece are small, $0.25 \mathrm{~mm}$., elosely approximated and rather deep, with a coneave anterior profile, and a slightly oblique margin marked by nine teeth, which increase in size towards the anterior of the ealycle. A distinet, horizontal septum traverses the hyllotheca cavity abont a fifth from the base. The supracalycine nematophores are small, just reaching the level of the hydrothecit margin. The mesial nematoplore is adnate for little more than half the lieight of the hydrotheca, and has but a short divergent "beak" free. There are two nematophores on each stem-internode, one opposite, the other clistal to, the hyclroclate-bearing process.

The stem is of a horny-brown colour, which fardes into a finint yellow towards the tip.

Gonosome. - The corlute are allout $1.7 \mathrm{~mm}$. in length hy $1 \mathrm{mun}$. in brewlth, elongate-oval in shapre, with 7 or 8 pain: of sorbule- 
leares, which are altogether free from one another. Every leaf bear's a row of 6 or 7 large bulging nematophores on each margin. The cenosare from which the portions supplying these nematophores branch off runs up one side of the leaf, sending off as it passes a short process into each nematophore on that side, and then, having passed a consilerable distance up the leaf, sends off a larger shoot which, running backwarls, supplies the nematophores along the other side. Conforming with this branching of the conosare, the cenosarc-containing eavity in the leaf also shows a backward-running branch connecteil with the nematophore-carities along one side (vide Pl. XXIV. fig. 10). Without the walls of this eavity there is a delicate chitinous membrane connecting the nematophores and forming a wing-like extension to the body of the leaf proper. The speeific name marginata indicates the presence of this extension. At the base of each leaf along only one side of the corbula there is a very small spm-like nematophore.

Locality. Growing on the bottom of lighters: St. Vincent, Cape Verde Islands; 20th and 30th July, 1904.

Litocarpts graxds, var. uxilatekalis, var, n. (Plate XXV. figs. 1, 2, 3.)

Nany much-branched colonies have been olstained from one locality: the largest, which is fragmentary, is $20 \mathrm{~cm}$. in beight, with a stem $6 \mathrm{~mm}$. in diameter above the first branch, and a large basal portion coverel with loose hydrorhizal tubes.

The stem is strongly fascicled and is diviled near the lase into several large branches, which bear smaller branches and so on sometimes to the sixth oriler. All the branches, except the smallest, spring from their parest branch on the sile remote from the stem, a rather unusual arraugement to which the variety owes its name. The hydroclade-bearing tubes are divided into regular internodes, 0.4 to $0.5 \mathrm{~mm}$. in length, each of which hears an alternate hydroclade almost on its anterior surface.

The hyclroclades, which are borne on a perforated process of the internode, are about $8 \mathrm{~mm}$. long, and are diviled into internodes $0.35 \mathrm{~mm}$. in length, each with two very strong septal ridges, one opposite the intrathecal rirlge and horizontal, the other less distinct opposite the base of the lateral lematophores and sloping obliquely upwards.

The hydrothece are closely approximated, deep, slightly bulging below, with nine teeth, seven of which are apparent while one on each side is hidlen by the lateral nematophore. The anterior tooth is slightly recurved. The intrathecal ridge is distinct and is horizontal, extending aromud the hydrotheca about $\frac{1}{5}$ from the base. The mesial nematophores are long, adnate almost to the top of the hydrotheca and then free for some distance. The free portion raries much in length, sometimes scarcely rising above the hydrothea on the proximal eul of a hydroclale while overtnping those on the distal portion for a consilerable distance (cf. Pl. XXV. figs. 2 it 3). In the supratycine nematophores 510 
the same variability occurs, those on the proximal hydrothece rising just clear of the margin, those in the distal produced into long, prominent "horns" reaching $0.1 \mathrm{~mm}$. beyond it. They bave two apertures, one terminal, the other lateral and just above the hydrotheca margin. The cauline nematophores, of which there are two on each hydroclade-bearing internode, one on a level with, the other proximal to, the base of the hydroclade, are large, from 0.1 to $0.2 \mathrm{~mm}$. in height, and triangular.

The colonies are of a rich dark brown colour which, however, is almost lacking in the more delicate hydroclades.

The gonosome is not present.

The specimens here described, although they differ from L. grandis (Clarke, 1879) in their unilateral mode of branching, agree so accurately with the minnte structure of hydrotheca and branch as described and figured by Versluys $(1899$, p. 51), that they have been referved to that species. The black granular pigment-cells observed by Nutting (1900) in the cœnosarc of $L$. grandis and $L$. clarke $i$ are present in considerable numbers in my specimens. The branching here described is similar to that of $L$. racemiferus of Allman (1883), but the specimens differ in the greater length of the bydroclades, the bulging shape of the lydrothece, the number of marginal teeth (apparently only five in Allman's figures), and the presence of a distal internodal septum. Allman does not mention the presence of cauline nematophores in his species.

Locality. St. Vincent, Cape Verde Islands: depth 15 fathoms; 30 th July, 1904.

Litocarpus crosslaxd, sp. n. (Plate XXIV. fig. 11; Plate XXVI. figs. 2, 3, 4.)

Colonies unbranched, springing from a creeping bydrorhiza and attaining a height of about $15 \mathrm{~mm}$. The stem is nonosiphonic, divided into regular internodes $0.3 \mathrm{~mm}$. in leugth, except the proximal millimetre which is undivided, and which is separated from the remainder by a deep constriction sloping downwards from posterior to anterior. The bydroclades, which are borne on each internorle, are placed anteriorly on the stem and are approximate and alternate. They are divided into regular internodes $0.25 \mathrm{~mm}$. long, each of which bears on its anterior surface a lhydrotheca, and contains two septal ridges, one opjosite the intrathecal ridge, the other under the lateral nematophores. In no case was a third septum, hetween the other two, observed.

The hrdrothece are closely approximated, and are marked in front by a deep fold which lrings the aperture into a vertical position. The margin has anteriorly a strong, sharp, uptimned troth and on each sile a prominent lobe, while the interior is divided into two regions by an intrathecal ridge projecting forwards from the internode about $0.5 \mathrm{~mm}$. from the bottom. A second stout intrathecal ridge projects backwards into the hydrothea from hetween the mesial nematophore and the margin.

Proc. Zuor. Soc--1907, No. XXXV. 
The mesial nematophore is long (almost $0.3 \mathrm{~mm}$.), reaching $0.05 \mathrm{~mm}$. above the level of the hydrathecal margin, adnate for little more than half its length, and with two apertures. The supracalycine nematophores are divergent, long and tubular, inclined at an angle similar to that of the mesial nematophore. and rising a short distance above the margin of the hydrotheca, to which they are adnate. On each stem-internorle there are two triangular nematophores, one proximal, the other distal to the hase of the hydroclade, while the base itself bears anteriorly at tubular nematophore.

Gonosome.-The gonangia are borne on modified recurverl hydrocladia, divided into about ten short internodes, the proximal bearing a hydrotheca, which is replaced on the following two or three internodes by a gonangium. Each of the remaining internotes bears one or two divergent tubular nematophores, each with two apertures, one terminal, the other in the angle formed between nematophore and internode. The gonangia are almost circular. and are much compressed. As many as twenty-two gonangia on eight phylactocarps were counted on one specimen. The arrangement of the nematophores on the phylactocarp suggests that which occurs in connection with the hydrothecr, two divergent nematophores frequently occurring at the same level and beneath them a single mesial nematophore.

Loculity. Growing on a leaf found in a bottle containin: tunicates from Mattiota, St. Vincent Harbour.

The trophosome of the present species is almost identical with that of Aglaophenia plumosa Bale (1884), but there the recurved gonangial pinna bears " $15-20$ pairs of alternate pinnules," these again bearing the nematophores which are arranged differently from those in the specimen before me, the whole structure forming a corbula.

\section{List of Literatere cited.}

Alder, J., ] 859.-- "Deseription of two new Species of Sertularian Zoophytes, found on the coast of Northumberland"; Ann. Mag. Nat. Hist. 3rd ser. vol, iii.

Allmax, G. J., 1864.- "Notes on the Hydroida"; ibid. 3rd ser. vol, xiv.

Altalax, G. J., 1871, 1872.-A Monograph of the Gymnoblastic ox Tubularian Hydroids. Ray Society. London.

Aldsax, G. J., 1877.- " Report on the Hydroida collected during the exploration of the Gulf Stream." Harvard Mus. Zool. Mem. 5.

Aldmax, G. J., 1883.- "Report on the Phumularians." "Challenger' Expedition, Sci. Reports, Zool., vol. rii.

Allmax, G. J., 1888,- "Report on the Hydroids," Part HI. ; ibid. rol. xxiii.

Bale. W. M., 1884.-A Catalogue of the Australian Hydroid Zoophytes. Sydney,

BENEDE, P. J. VAצ, 1844.-- "Recherches sur l'Embryogénie des Tubulaires"; Nouv. Mém. de l'Acad. de Brux, tome xvii.

billard, A., 1904.- "Contributions à l'étude des Hydroìdes"; Ann. des Sci. Nat. sér. 8, vol. xx.

512 
Billard, A., 1906.--"Hydroïles: Mission des Pècheries de la Côte Occidentale d'Afrique"; Actes Soe. Linn. de Bordeaux, vol. lxi.

Billard, A., 1907.-Hydroïdes: Expéditions scientifiques du 'Travailleur' et du 'Talisman,' tome viii.

Clarke, S. F., 1879.-Bull. Mus. Comp. Zool. Harv. Coll., vol. v. no. 10.

Delage, Y., 1901. -Traitè de Zoologie Concrète, tome ii. part. 2. Les Culentèrés.

Ehrexberg, C. G., 1832.- "Beitrag zur phys. Kenntniss der Corallenthiere im Allgemeinen und besonderes des Rothen Meeres"; Abh. der Berlin. Akad.

Ellis, J., \& Solaxder, D., 1786.-The Natural History of many curious and uncommon Zoophytes collected from rarions parts of the Globe. London.

Fowler, G. H., 1900.-The Hydromeduse: in 'A Treatise on Zoology,' edited by Prof. E. Ray Lankester, Part II.

Hartlacb, C'L., 1905.-- "Die Hydroiden der magalhaenischen Region und chilienischen Kuiste"; in Fauna ChilensisSuppl, vi. to Zoolog. Jahrbücher.

Hassall, A. H., 1852.-Trans. Mier. Soc, vol, iii.

Hricks, T., 1863.-Ann. Mlag. Nat. Hist, 2nd ser. vol. xi.

Hгscks, T., $1866 .-$ Ibid. vol. xviii.

Hixcks, T., 1868.-A History of the British Hydroid Zoophytes. London.

Joнхsтov, G., 1838. - A History of British Zoophytes. Edinburgh.

Kirchexpauer, G. II, 1864.- "Ueber neue Sertulariden." Acta Ac. German, xxxi, pp. 1-16.

LAvarck, J. DE, 1816.-Histoire naturelle des animaux sans vertèbres, vol. ii. Paris.

Lixxæes, 1758.-Systema Naturre, ed. 10.

Lovéx, S., 1835.- "Bidrag till kännedomen af slægterna C'ampamelaria och Syncoryna"; Handl. Srensk. Akarl. Stockholm.

McCradr, J., 1857.- Proc. Elliott Society, April 1857.

Nutixg, C. C., 1900._-"American Hydioids." Part I. Plumularide; in Special Bull. Smithsonian Institution.

Nutrisg, C. C., 1904.-Ibid, Part II. Sertularide. Tbid.

Pictet, C., 1893.- "Etude sur les Hylraires de la Baie d'Amboine" ; Rev. Suisse Zool, vol, i,

Qcerch, J. J., 1885.- "Deep-sea and Shallow-water Hydrozoa"; Ann. Mlag. Nat. Hist. 5th ser, vol. xri.

Rгтсние, J., 1907.- " Hydroids of the Scottish National Antaretic Expedition"; Trans. Roy. Soc. Edinburgh, vol. xlv. jart 2.

SARs, M., 1851.- "Beretning om en Zoolog.-Reise in Lofoten og Finmarken"; Nyt Mag. Naturvid, vol. vi.

Thorxelt, Laura R., 1904.- "Hydroida"; in Report on the Pearl Oyster Fisheries of the Gulf of Manaar, by Prof. Herlman, F.R.S. Suppl. Rep. vol, viii. Roya Soc. London.

Versulys, J., 1892.- " Hydraires Calyptoblastes recueilles dans la mer des Antilles"; Mém. de la Soc. Zool, de France, tome xii. 
WARREN, E., 1906.- "On Tubularia solitaria, sp. n., a hydroid from the Natal Coast"; Annals of the Natal Gov. Mus., rol. i. part 1 .

WeIsmaxx, A., 1883,-Entstehung der Sexualzellen bei den Hydromedusen. Jena.

\section{EXPLANATION OF THE PLATES.}

\section{Plate XXIII.}

Fig. 1. Coryne (?) dufium, sp. n. A complete colony to show abundance of branching. $\times 4 . \quad$ (p. 191.)

2. Coryme (?) dubium, sp. n. Fragment, showing polyps and origin of branches. $\times 30$. (p. 491 .)

3. Campanitaria mutabilis, sp. ए. Specimen from St. Vincent, with regenerated margin. $\times 20$. (p. 504.)

4. Campanularia mutabilis, sp. n. Specimen from St. Vincent, showing asymmetry. $\times 20$. (p 504.)

5. Campanularia mutabilis, sp. n. Specimen from Porto Praya. $\times 20$. (p. 501.)

6. Hydractinia verdi, sp. n. Portion of colony with polyps in various states of contraction. $\times 20$. (p. 498.)

7. Hydractinia verdi, sp. n. Reproduetive person bearing gonophores with pva. $\times 50, \quad$ (p. 498.)

8. Podocoryne anechinata, sp.n. Portion of colony with nutritive and reproductive person. $X$ circ. 30 . (p. 199.)

9. Podocoryne anechinata, sp. n. Medusoid before it is set free. $\times 90$. (p. 199.) 10. Podocoryne anechinata, sp, n. Chitinous tubes forminz mesh-like basal Podocoryne anechinata, sp. n.

11. Ophiodes caciniformis, sp. n. Colonies creeping upon fragment of wormtube. Nat. size. (p. 500.)

12. Ophiodes caciniformis, sp. $\mathrm{n}$. General structure of colony. $\times 15$. (p. 500.)

Plate XXIV.

Fig. 1. Ophioiles caciniformis, sp. и. Hydrauth, hydrotheca nematophore, \&c. $\times 40$. (p. 500.)

2. Sertularia versluysi Nutt. Claster of colonies. Nat. size. (p. 505.)
3. Fragment of colony sbowing arrangement of

3. " " $\quad$ bragment of colony sbowing

4. $" \quad$ Hydrothecre from front. $\times 50$. (p. 505.)

5. " " " Hydrothecæ from side. $\times 50 . \quad$ (p. 005.$)$

6. " " Gonangia. $\times 25$. (p. 505.)

7. Aglaophenia marginatc, sp. n. Colonies. Slightly reduced. (p. 509.)

S. $"$ Hydrotbece. $\times$ o0. (p. 509.)

9. $" \quad$ " $"$ Corbnla, $\times 40$. (p. 509.)

11. Lytocarpus crosslandi, sp. n. Colonies on leaf. Nat. size. (p. 511.)

\section{Plite XXY.}

Fig. 1. Lytocarpus grandis, var. unilateralis, rar. v. Fragment of colony showing mode of brauching. Nat. size. (p. 510.)

2. Lutocarpus grandis, var. unilateratis, var. n. Hydrothecæ from base of a hydroclade. $\times 50$. (p. 510 .)

3. Lytocarpus grandis, var, unilateralis, rar. n. Hydrotbecæ from tip of a irdroclade, $\times$ 5t). (p. 510.)

4. Monostachas quadridens (Mclrady). Showing cyme-like origin of steminternodes. $\times 20$, (p. 508.)

5. Ophiodes caciniformis, sp, n. Protruded nematocyst. $\times 700 . \quad(\mathrm{p}, 501$.

Plate XXVI.

Fig. 1. Soleniopsis dentriformis, gen. et sp. nor. Colony. Nat. size. (p. 495.)

2. Lytocarpus crosstandi, sp. n. Phylactocarp, with siugle gonangium.

3. $\quad$ Pliylactocarp. $\times 45 .(\mathrm{p} .511$.
4.

5. Sertularia lavimarginata, sp. n. Colouies on a leaf. Nat. size. (p. $50 \overline{7}$.)

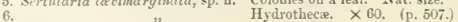




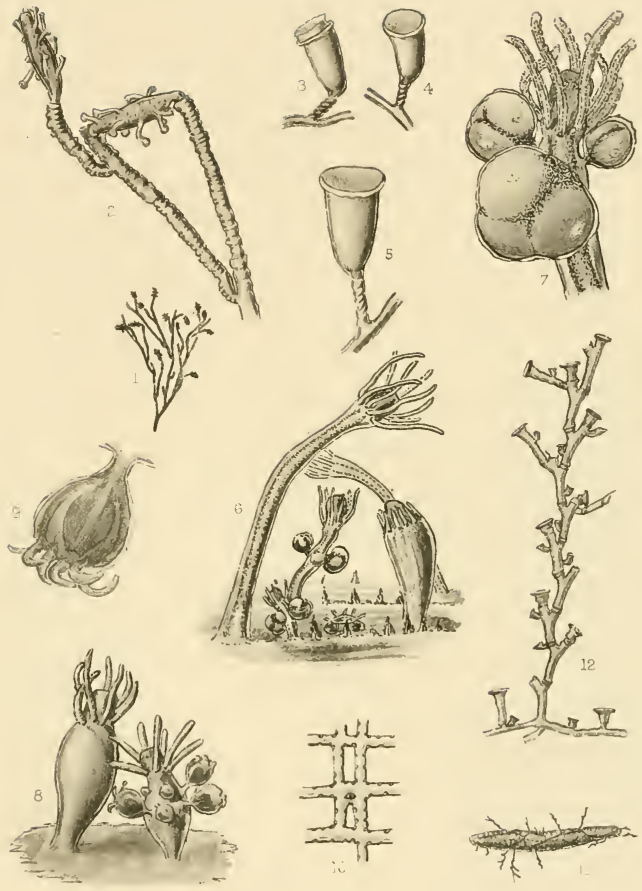





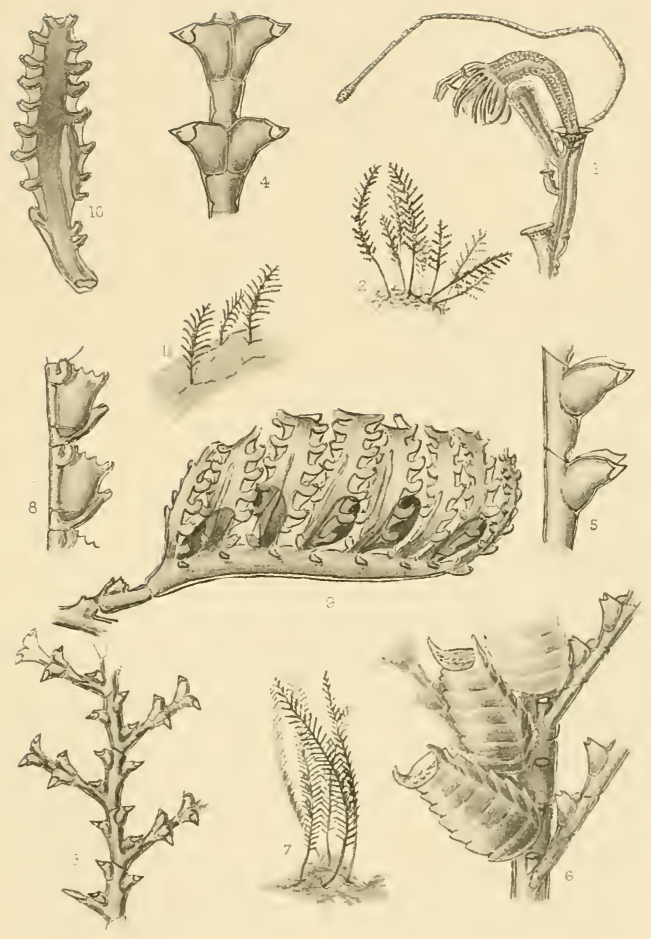





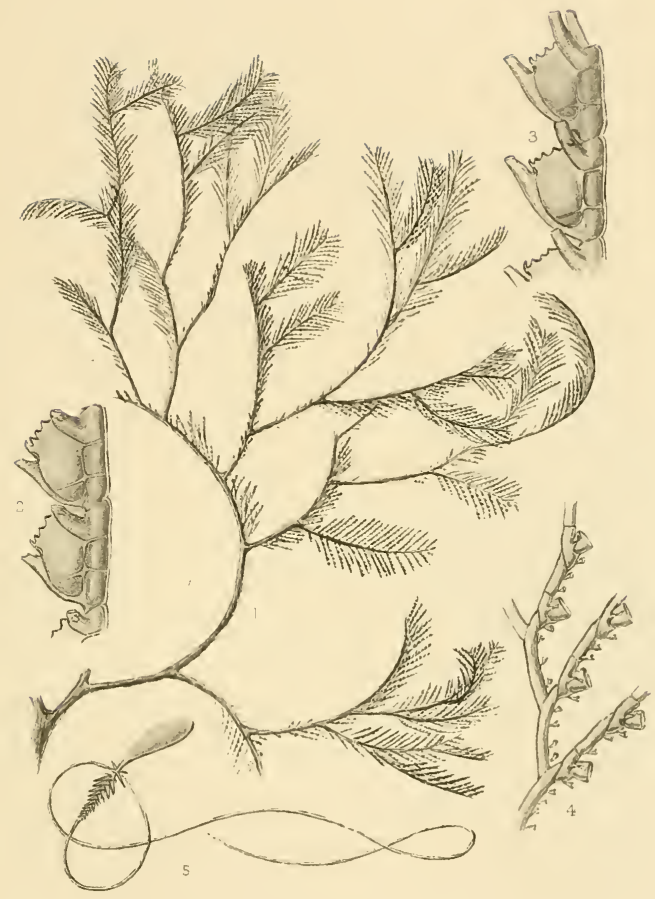

Jas Fitchie, del

FYDROTDS FROM CAPE TERIE J:I AND? 



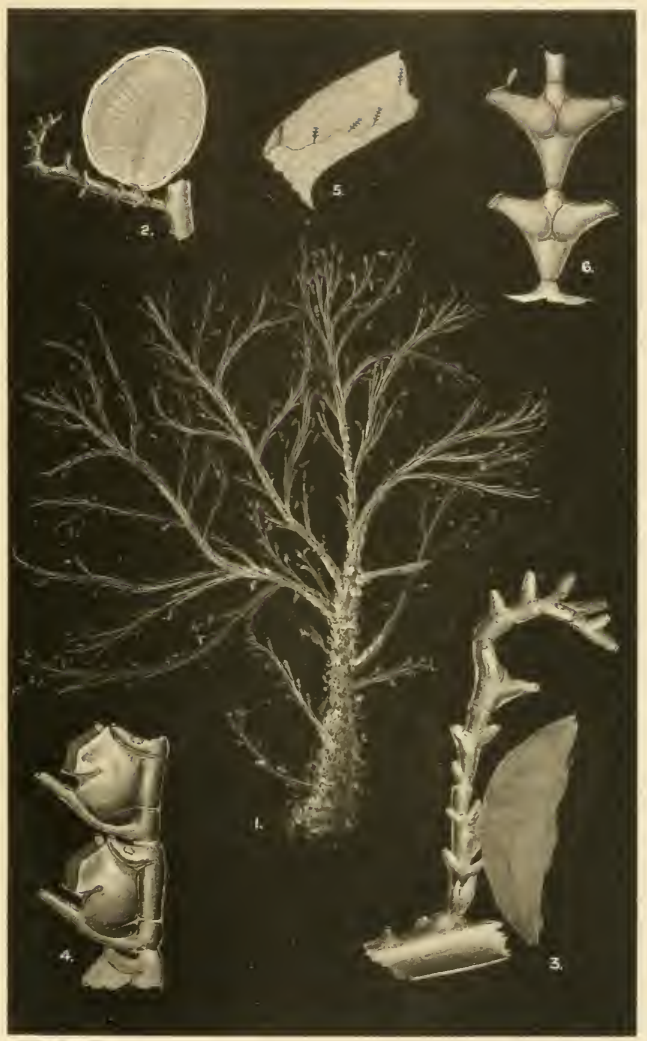

Jas 2trtiul ief

senden sleno :op. The init

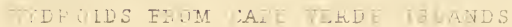



XI. A lury, Tubulurian (Tubularia regalis, Boent from the Moray Firth. By Prof. J. Arthur Thomson, M.A.

(Read 16th December 1907.)

On 23rd March 1907, the "Goldseeker," engaged in the international scientific exploration of the North Sea, dredged from a depth of 39 fathoms in the Moray Firth $\left(58^{\circ} \mathrm{N}, 2^{\circ} 38^{\prime} \mathrm{W}\right.$.) a magnificent colony of a species of Tubulariu, which seems to be an addition to the list of British Hydroids. Through the kindness of Prof. D'Arcy W. Thompson, C.B., I obtained the specimen for examination, and my conclusion is that it is referable to Tubularia regalis, described in 1859 from spitzbergen by Chr. Boeck.

The beautiful cluster of polyps is about a foot in height, and strikes one at once as larger and more substantial than sinilar clusters of the common Tubularia indivisa, which it resembles in general colouring. The height of a single hydrocaulus, measured apart from the interlaced tangle at the base, varies from $7-10$ inches, and to this the large bydranth may add nearly another inch $(20-22 \mathrm{~mm}$.). The breadth of the hydrocaulus is about $3 \mathrm{~mm}$., and the largest bydranth at its broadest part has, in the contracted preserved state, a width of about $20 \mathrm{~mm}$. There are $12-15$ longitudinal lines on the clear perisare, corresponding to vermilion lines on the conosarc which shine through.

There are 32-36 proximal tentacles from $12-22 \mathrm{~mm}$. in length, and the maximum spread of the tentacles, measured along a diameter of the circle which they form, is about $60 \mathrm{~mm}$. The distal tentacles form a dense brush, consisting of several close tiers around the mouth. From 76 to 92 were counted on various hydranths. Each distal tentacle is about $4 \mathrm{~mm}$. in length, $0.4 \mathrm{~mm}$. across the base, tapering to $0.1 \mathrm{~mm}$. at the tip.

Immediately above the bases of the proximal tentacles, 12 to 14 unbranched blastostyles or pendulous racemes 
of gonophores are inserted. They hang down, regularly interpolated, among the proximal tentacles, which they equal in length $(12-22 \mathrm{~mm}$.). On several of these pendulons racemes, 48 gonophores were counted. The gonophores are oval in form, with average diameters of $1 \mathrm{~mm}$, and $2 \mathrm{~mm}$. Some of them show a very long spadix, but there is no trace of radial canals.

The question of present interest is, To which species of Tubularia does this magnificent Moray Firth specimen belong? We may at once dismiss the small species, such as T. larymx and T. bellis, and confine our attention to those which are often or usually over 6 inches in length, namely, T. regalis, Boeck, T. indivisa, L., T. variabilis, Bonnevie, and T. insignis, Allman.

Taking the last first, we find that, according to Allman, the hydrocaulus of $T$. insignis attains a height of 7 inches or more. Indeed, the monographer notes that "it far surpasses in size every British representative of the genus." But the hydrocaulus of our Moray Firth specimen may attain a height of 10 inches. The hydranth of $T$. insignis (which was found at Dieppe) was about half an inch in height from base to summit, but several hydranths in our specimen originally stood up for nearly an inch. The mention these facts to emphasise the large dimensions of our specimen. We need not, however, delay over $T$. insignis, for besides differing markedly as regard its tentacles, it is removed from any close systematic proximity to our specimen by more important differences relating to the blastostyles. In $T$. insignis the blastostyles are "in six or seven imbricated verticels, with about twenty in each verticel, not pendulous," whereas our specimen has 12 to 14 pendulous blastostyles.

The next on the list is the large T. reriabilis, Bonnevie, which has a height of $100-300 \mathrm{~mm}$., distinet longitudinal striping, 25-35 proximal tentacles (15-20 mm. in length), $10-20$ blastostyles $(20 \mathrm{~mm}$. in length), and is thus in many respects like our specimen. But it again may be left ont of account, since its gonophores are characterised by 3-6 high extemal ribs corresponding to a similar variable number of 
radial canals, whereas the gonophores of our specimen have no ribs and show no radial canals. For similar reasons, we need not consider either $T$. asymmetrica, Bonnevie, or T. oblique, Bonnevie, which have rudimentary tentacles on the gonophores.

Is it then possible that the Moray Firth specimen is simply a very large and luxuriant representative of the common $T$. indivisk, perhaps like the vaguely known T. gigunter of Lamouroux, which attained a height of $12-15$ inches, and was regarded by Allman as "probably only a large form of $T$. indivisa"? If the radial canals are absent from the gonophores of the Moray Firth specimen, as they appear to be, then it cannot be identified with $T$. indivisa, whose gonophores have four radial canals; but it seems undesirable to press this point, since our specimen has not been adequately fixed. The difficulty of deciding whether our specimen is or is not referable to $T$. indivise is complicated by the fact that there are considerable differences between Allman's and Hincks's descriptions. The real difficulty is that we cannot judge as to the specific value of numerical and quantitative differences without examining a large number of specimens, which we have not, as yet, been able to do.

It may be pointed out that the difference between Allman's " 40 distal tentacles" and our $76-92$ is very considerable, but Hincks simply says "very numerous." Similarly, the difference between Allman's " 3 or 4 pendulous racemes of gonophores" and our 14 is also very considerable, but again Hincks says "numerons." On the whole, however, the numerical and quantitative differences seem to warrant us in separating our specimen from $T$. indivisa, and it seems to us that it should be referred to Boeck's Spitzbergen species, T. reyelis.

In contrasting $T$. indivise and $T$. regalis, Miss Bonnevie notes that the former has 4 radial canals on its gonophores, while the latter has none; that the former has $20-30$ proximal tentacles, about $10 \mathrm{~mm}$, in length, while the latter has $20-30,20-40 \mathrm{~mm}$. in length; that the former has $3-10$ blastostyles, while the latter has $10-20,35 \mathrm{~mm}$. in length. 
Our specimen resembles $T$. regalis (1) in having bright red longitudinal lines on the cœnosarc, which are seen shining through the clear perisarc; (2) in the breadth of the hydrocaulus (3 mm.); (3) in the great height and breadth of the liydranth; (4) in the length of the proximal tentacles (up to $22 \mathrm{~mm}$.) ; (5) in the length of the distal tentacles $(3-4 \mathrm{~mm}$.$) ; (6) in the shape and arrangement and length$ of the blastostyles; (7) in the long spadix within the gonophores; and (8) in showing no trace of radial canals.

Our specimen differs from $T$. regalis, as described by Boeck, (1) in having 32-36 proximal tentacles instead of 28 , but Bonnevie says $20-30$; (2) in having shorter proximal tentacles and blastosyles, $12-22 \mathrm{~mm}$. instead of $42-45 \mathrm{~mm}$., but Bounevie gives 20-40 mm. as the length of the tentacles and $35 \mathrm{~mm}$. as the length of the blastostyles. It should also be noted that our specimen was considerably contracted by preservation before the measurements were taken. Boeck figured the blastostyles as if they stood up vertically, but Allman pointed ont that this position is impossible.

Before giving a tabular comparison, which will show the resemblances and differences at a glance, we may supplement the descriptions of $T$. regalis by a reference to the hydrorhiza, which was absent in the specimens obtained by the Norwegian North Atlantic Expedition, and was left unnoticed by Boeck. As Miss Bonnevie supposed, the lower part of the hydrocaulus is composite, as in T. indivisa. The stems are twisted together in a tangle at the base. It may also be noted that one hydrocaulus bears a small bainacle, Scalpellum vulgare. 
73

\begin{tabular}{|c|c|c|c|c|c|c|}
\hline & & & & 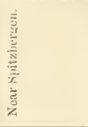 & 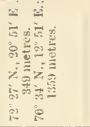 & 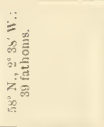 \\
\hline 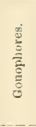 &  & 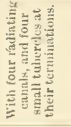 & 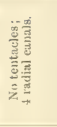 & 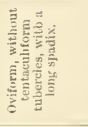 & 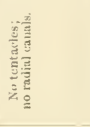 & 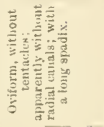 \\
\hline 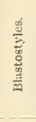 &  & 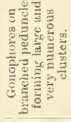 & 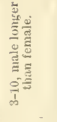 &  & 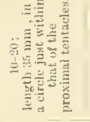 & 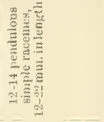 \\
\hline 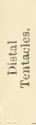 & $\stackrel{9}{+}$ & 总 & 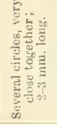 & 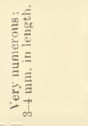 & 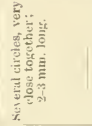 & 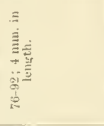 \\
\hline 表 & $\begin{array}{l}\dot{\phi} \\
\text { \&े }\end{array}$ & 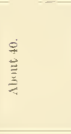 & 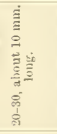 & 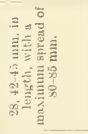 & 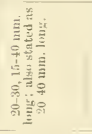 & 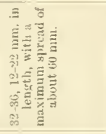 \\
\hline 产 & & & & 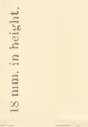 & 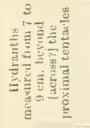 &  \\
\hline 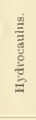 & 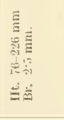 &  & 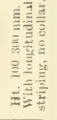 & 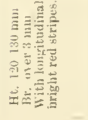 & 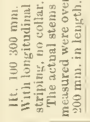 & 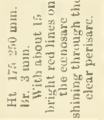 \\
\hline 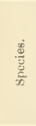 & 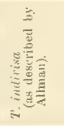 & 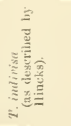 & 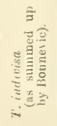 & 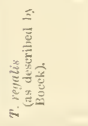 & 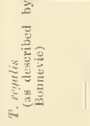 & 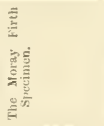 \\
\hline
\end{tabular}


The results of this short note on a very beautiful specimen may be summed up in a sentence. There exists in the Moray Firth a large species of Tubularia, differing considerably from the familiar $T$. indivise, and closely resembling $T$. regalis; if it be referred to the latter, as seems justifiable, a new record is made for British waters, and a distinctively northern form, previously recorded from near spitzbergen and from far to the north of Norway, is shown to have an interesting extension of its range southwards.

\section{References to Literature.}

Воеск, Cнr., Om Tubularia regalis, en ny Art fra Belsund paa spitsbergen. Forhandlingur $i$ Tidenskabs Selskabet $i$ Christienia, 1859, pp. 11t-11 $i, 1$ plate.

Hixcks, Tul, A History of British Hydroid Zoophytes. London, 1868 (see pp. 114-118).

Alluax, G. J., A Monograph of the Gymnoblastic Hydroids. Ray suciety, London, 18i2 (see pp. 398).

Bonsevie, lifistixe, Hydroida-The Norregian Torth-dtlantic Expedition, 1876-i8, vol. vii., Christiania (1899), pp. 100, 8 pls. (see pp. 25 and 27 , Pl. I. fig. 5 ). 
XVII. Note on a Large Antipatharian from the Foroes. [Plate XI.] By Prof. J. Arthur Thomson, M.A.

(Read 24th February 1908.)

In the summer of 1907 I obtained from Mr George Sim, Aberdeen, a remarkable specimen which had been brought in by a trawler "from the north-east of the Froe Islands." It was remarkable in being an Antipatharian, for the occurrence of a representative of this order in northern waters near Britain was, to say the least, unexpected. It was remarkable in the second place, because of its huge size, for it stood over a yard in height. I wish to take this opportunity of thanking Mr Sim for his kindness in allowing we to have this interesting specimen for the University Museum. This is indeed but a minor instance of the disinterested way in which the indefatigable and learned author of The Vertebrate Fauna of Dee has placed valuable material, as well as knowledge, at the service of scientific workers in many departments of Zoology. A word of appreciation may also be permitted in reference to the sagacity of the fishernan who recognised that the Antipatharian was "something new," and took the trouble to bring the large specimen home.

The specimen stands $3 \mathrm{ft} .2 \frac{1}{2}$ ins. high, and consists of a substantial main stem with more than half a dozen strong brancbes. It is attached by a broad base ( $1 \frac{1}{2}$ ins. $\times 1 \frac{7}{8}$ ins.) to a stone which measures $9 \times 7 \times 3 \frac{1}{2}$ ins. and weighs several pounds, so that all thought of the specimen having been washed from elsewhere is out of the question. The main stem has for the greater part of its length a diameter of about $8 \mathrm{~mm}$, and its section shows the well-known characteristics of "black coral." Five branches which remain fairly complete attain a very considerable length, the longest being almost as long as the main stem (2 $\mathrm{ft} .8$ ins.). It should be noted that the intact specimen must have been much more than a yard in height, for the main stem is broken off' while stıll showing a diameter of about $7 \mathrm{~mm}$. 
There have been at least eight fairly strong primary branches, arising irregularly and at various angles from the main stem, and one of these which was broken off, and was heavily weighted with large clusters of barnacles (Scalpellum vulgare), had an irregularly elliptical section, about $8 \mathrm{~mm}$. by $6 \mathrm{~mm}$. From the strong primary branches a few secondary branches arise, and all the branches bear very numerous twigs or pinnules, with which the main stem was also beset, as the more or less broken stumps plainly show. The twigs or pinnules arise on all sides of the primary and secondary branches in somewhat irregular vertical rows. They arise for the most part at right angles, and in some parts there are rather vague indications of six vertical rows. As many as forty-eight pinnules may occur on a centimetre, and thus a dense bottle-brush appearance results. The twigs or pinnules have a thread-like axis $(0.18 \mathrm{~mm}$. in diameter), and stand out stiftly, but they are as flexible as a fencing-foil.

Only a few spines were seen on the branches, but they occur in typical abundance on the delicate twigs. Three rows are fully visible on one aspect, and there are actually six vertical rows. These spines are minute, fairly sharp triangles, curved slightly upwards and not closely appressed. In many cases they project for $0.09 \mathrm{~mm}$., but they are not all of the same size. Those observed on the branches are larger but lower than those on the pinnules, and even on the same pinnule there is some inequality. The distance between two adjacent spines on a vertical row varies from 0.5 to $0.75 \mathrm{~mm}$., and is by no means regular.

The reason for these details will be obvious when I mention the unfortunate fact that not a word can be said in regard to the polyps of this interesting specimen. When it came into my hands, it showed abundant remains of the conenchyma, but no definite trace of any of the polyps could be found. Two or three of the best pieces were immediately fixed, but they only showed that the polyps were hopelessly decomposed. This is peculiarly unfortunate, because it is very difficult to identify an Antipatharian apart from its polyps. 
In the absence of any polyps, I could not do more than give close attention to the mode of branching, the arrangement of the twigs, and the disposition and character of the spines. By comparing the Færoe specimens with others, and by following a method of exclusion, I have convinced myself that it is referable to the well-known Mediterranean species-Parantipathes larix (Esper), see Brook (1889, p. 142). If this conclusion is correct, the occurrence of this species to "the north-east of the Færoe Islands" is of great interest, which is increased by Professor Hickson's record (1907) that Parentipathes laric was co!lected by the "Huxley" from the north side of the Bay of Biscay in August 1906.

Recognising the scientific responsibility of stating that a well-known Mediterranean species occurs in such high latitudes as north-east of the Færoes, I have carefully considered all the Antipatharians in Brook's "Challenger" Report and in subsequent publications, and I find that, apart from Parantipathes larix, there is only one other Autipatharian which the Færoe specimen resembles in any marked degree, and that is Taxipathes recte, Brook (1889, p. 156), which is only known by a single specimen, obtained off Ascension. That this species cannot include the Freroe specimen might perhaps be inferred from the distribution, but as that is a dangerous way of arguing, I may point out that, while Taxipathes recta resembles Parantipathes larix and our specimen in certain respects, e.g., in having the same kind of delicate simple pinnules arranged in a brush in six vertical rows, it may be left out of consideration because of its extremely stiff rectangular branching, its rigid and absolutely regular pinnules (only 18 to 21 to a centimetre, moreover), and its spinulation (with four vertical rows of spines on one aspect). It need hardly be said that the presence of eveu a few polyps would have obviated even a minute's consideration of whether the form in question was referable to the Schizopathinie, among which Taxiputhes is included, or to the Antipathine, among which Parantipathes is included.

The real difficulty in regard to the specimen from the 
Færoes is that it caunot be regarded as a typical representative of the species to which it seems most reasonably referable, namely Parantipathes larix. It differs from the type in having several branches from the main stem, in not having the pinnules of a row strictly in one plane, in having more numerous pinnules (over 20 in three $\mathrm{cm}$. of one vertical row, instead of about 11), and in having flexible, not "rigid," pinnules. But in Brook's detailed description it is stated that the pinnules of a row are "almost in one plane," and we may also note that the pinnules of a fine specimen of Parantipathes larix from Naples, are anything but rigid in the sense that an icicle is rigid. They are flexible like a foil.

Our specimen agrees with Parantipathes larix in having the pinnules in six vertical rows (though these are decidedly irregular), in having six pinnules to one revolution of the axis, in showing three longitudinal rows of spines on one aspect of a pinnule, and in having similar spines not uniform in size. We have compared a pinnule of a Naples specimen with a pinnule from the Froes specimen, and we find them practically identical. Therefore we conclude that the Færoes specimen is referable to P. larix, although it deviates from the type in certain respects, such as branching. The deviations may be growth-reactions to a very different environment.

We make no apology for entering into details on this subject of specific identification, for in all such questions one is only too apt to err in the opposite extreme. At first sight it seemed impossible to identify the weathered specimen from the Færoes with a perfectly preserved specimen from Naples, yet we think that this is necessary. This means that Brook's description of the species as $(a)$ with stem "simple or rarely branched near apex," (b) with pinnules in six planes, and (c) with pinnules rigid, about 11 in each vertical row for $3 \mathrm{~cm}$., requires to be modified in regard to each of these points. When we think of plants, e.g., forms like "Shepherd's Purse" and "Whitlow Grass," to which the ramose colonial Cœeleutera are in so many ways comparable, or when we think of 
many of the hydroids, we can well understand that divergences in regard to growth-characters are to be expected between representatives of the same species of Antipatharian, living in growth-conditions so diverse as those afforded by the relatively sheltered Mediterranean and the stormy seas to the north-east of the Freroes.

In discussing North Atlantic Antipatharians, Brook noted that "Antipathes (?) arctica, Litien, is apparently the only species which has been obtained north of latitude $47^{\circ} \mathrm{N}$.; it has been obtained on two occasions off the coast of Greenland. The occurrence of Cirripathes spiralis (Linn.) off the coast of Norway appears to me very doubtful, and requires confirmation before the species can be admitted into the above list" (Challenger Report, xxxii, 1889, p. 182).

On this statement three notes may be made:-

(1) Liitken's remarkable species, Antipathes arctica, from North Greenland, bears no resemblance to the specimen from the Færoes.

(2) The Froes lie between $61^{\circ}$ and $62^{\circ} \mathrm{N}$., which is far to the north of the $47^{\circ}$ which Brook mentioned as the highest latitude known for any North Atlantic Antipatharian except Lütken's species.

In 1905 Prof. Hickson recorded the occurrence of three Antipatharians from the West Coast of Ireland (about $53^{\circ}$ and $54^{\circ} \mathrm{N}$.), but these forms have not been reported on as yet.

(3) The three Antipatharians recorded by Prof. Hickson from the north of the Bay of Biscay, namelyStichopathes spiralis, Pourtales, Parantipathes larix, Esper, and Schizopathes crussa, Brook, were not obtained from higher latitude than $48^{\circ} 7^{\prime}$ N. Six specimens of $P$. larix were obtained from latitude $48^{\circ} 7^{\prime} \mathrm{N}$., longitude $8^{\circ} 13^{\prime} \mathrm{W}$., 412 fathoms. They varied in length from $225 \mathrm{~mm}$. to $325 \mathrm{~mm}$., and were therefore small in comparison to the Freroes specimen.

Of other definite records of Parantipathes larix I have not been able to find more than the following:- $(a)$ in 1896 Prof. L. Roule dredged this species in the Bay of 
Biscay from a great depth (1220 metres); (b) His Serene Highness the Prince of Monaco collected this species (1886-1902) from four stations, of which the farthest north was $43^{\circ} 57^{\prime}$, while the nearest the equator was $15^{\circ} 17^{\prime} \mathrm{N}$. The inference seems to be that the distribution of Parantipathes larix is remarkably widespread. It is interesting to notice that in three of the four specimens dredged by the Prince of Monaco the polyps were absent, as in our specimen.

\section{SUMMARY.}

A large Antipatharian, over a yard in height, consisting of a strong main stem with several long branches, was trawled to the north-east of the Færoe Islands. Numerous filiform pinnules, arranged in six irregular rows, give the branches a bottle-brush appearance. The pinnules bear six vertical rows of minute triangular spines. For these reasons the specimen is referred to Parantipathes larix (Esper), and the reference involves a slight modification of the diagnosis of the species, as well as a great extension of its previously recorded range of distribution.

\section{Pieferences.}

1788-1790. Esper, E. J. C., Die Pfanzenthiere. Nürnberg.

1865. Lacaze-Duthiers, H. De, Mémoire sur les Antipathaires (gen. Antipathes), Amales des siciences Vaturelle, Zoologie, sér. 5, vol. iv. Pp. 1-61, 4 pls.

1871. Lёткеx, C. F., Antipathes aretica, en ny sort koral fra Polar havet, Orersigt K. Danske Vidensk. Selskiabs Forhandl, pp. 18-26, 3 figs. Also Ann. Mag. Wat. Hist., ser. 4, rol. x. pp. 77-83.

1889. Brook, G., Antipatharia, Report on the Scientific Results of the Toyage of H.M.S. Challenger., vol. xxxii. p. 14 ?.

1896. Rovle, L., Ceelentérés, Résultats scientifiques de la Campagne du Caudan dans le Golfe de Gascogne, Annales de l'Liviversité de Lyon, xxvii. p. 199. 
1905. Roule, L., Résultuts des Campagnes Scientifiques accomplies sur son yacht par Albert I*r. Prince Souverain de Monaco, Fascicule xxx. Description des Antipathaires et Cérianthaires Recueillis par S.A.S. le Prince de Honuco dans l'Atlantique Nord (1886-1902), p. 75 .

1905. Hickson, S. J., Remarkable Colenterata from the West Coast of Ireland, Nature, lxxiii. p. 5. See also "Report on Sea and Inland Fisheries of Ireland for 1905."

1907. Hickson, S. J., The Alcyonaria, Antipatharia, and Madreporaria collected by the "Huxley" from the north side of the Bay of Biseay in August 1906, Jour. Marine Biol. Association, viii., No. 1, p. 10.

\section{Explanation of Plate.}

The large figure represents the complete colony of Parantipathes larix; the inset a portion of a branch showing pinnules. 



$$
11
$$



[Extracted from the LinNean Society's Journal-Zugligy, vol. xxxi. November 1908, pp. 48-75.]

\section{REPORTS ON THE MARINE BIOLOGY OF THE SUDANESE RED SEA.}

VIII. THE ALCYONARIANS.

BY

Prof. J. ARTHUR THOMSON, M.A.,

AND

Mr. JAMES M. McQUEEN, M.A., B.Sc., ONIVERSITY OF ABERDEEN. 
Riports on the Marine Brology of the Sudasese Red Sea.-Vill. The Alcronarlans. By Prof. J. Arther Thomson, M.A., and Mr. James MI. McQUeEN, M.A., B.Sc., University of Aberdeen. (Communicated by Professor Herditan, D.Sc., F.R.S., President.)

(Plates 5-8 and 4 Text-figures.)

[Read 5th December, 1907.]

THIs collection of Aleyonarians was made in 1906 by Mr. Cyril Crossland, M.A., B.Sc., on and off the shores of the Red Sea, in the course of his investigation of the Sudanese marine fanna. The localities where he collected were:- Suakim, Khor Dongola, Mersa Makdah, Shubuk, Matala, Etuleh, Wadi Lehama, Kal el Kebira, Shab Baya, Rawaya, and Agig. The indefatigable collector has furnished ns with a few notes as to the colour of some of the living animals.

The collection includes the following 26 species :-

1. Stolonifera.

Claveluria pulchra, Thomson and Henderson.

Sympodium fuloum (Forskål).

II. Alcronaces.

Tubipora purpurea, Pallas.

Xenia umbellata, Lamarck.

" cerulea, Ehrenberg.

" fuscescens, Ehrenberg.

Alcyonium spherophorum (Ehrenberg).

Sarcophytum glaucum, Quoy et Gaimard.

Sclerophytum gardineri, Pratt.

" querciforme, Pratt.

", densum (Whitelegge).

Lithophytum arboreum, Forskal.

" brassicum (May).

" thyrsoides (Ehrenberg).

, crosslandi, n. sp.

" macrospiculatum, n. sp.

Jephthya zanzibarensis, Thomson and Henderson.

„ albida ( $\mathrm{Holm})$.

Spongodes hemprichi, Klunzinger.

" hartmeyeri, Kükenthal.

" suesiana, n. sp.

III. Pskudaxonia.

pharonis, n. sp.

Melitodes coccinea (Ellis).

" splendens, n. sp.

Clathraria rubrinodis, Gray.

" acuta, Gray. 
Order I. STOLONIFERA, Hickson.

Clatularia pelchra, Thomson and Henderson (1906).

See J. Arthur Thomson and W. D. Henderson: "Alcyonaria of Zanzibar and BritiEast Africa from Collections made by Cyril Crossland," Proc. Zool. Soc. 1906, p. 4n:

A large colony growing on a pearl-oyster shell and on the stone to which the shell is attached.

The polyps, which arise from a strong basal membrane, are large and substantial; the body varies from 10 to $30 \mathrm{~mm}$. in length, and from 2 to $3.5 \mathrm{~mm}$. in breadth; the tentacles are 5 to $10 \mathrm{~mm}$. in length. There is a very marked hypostome, about $1 \mathrm{~mm}$. bigh. There are 28 pinnules on each side of a tentacle, and they are for the most part very long and slender. In some cases, however, they are almost wart-like. This diversity depends in this case on the degree of contraction.

The whole surface of the colony glistens with calcareous rods; the following measurements were taken of their length and breadth in millimetres : $-0.054 \times 0.018 ; 0.09 \times 0.0 .2$.

Locality.-Khor Dongola, 10 fathoms : previously recorded from Zanzihar shore.

\section{SrMPOdicM FULvum (Forskål).}

= Lithophyton fulvum, Forkbal (1775).

Sympodium fuloum, Ehrenberg (1881).

See W. May: "Beitrage zur Systematik und Chorologie der Alcyonaceen," Jenaische Zeitschr. Naturwiss. xxxiii. (1899) p. 52.

W. Kiikenthal : "Ueber einige Korallenthiere des roten Meeres," Festschrift ron E. Haeckel, 1904, p. 41.

A large number of specimens seem to be referable to this species, the only noteworthy difference from the type heing that the general spicnles of the cœnenchyma are not visible to the naked eye. A characteristic feature is the armature of the polyp-body, which consists of eight double rows of spicules arranged in chevron, and with some horizontally disposed spicules at the hases of the rows. According to Kiikentbal. this type should be referred to Alcyonium.

Locality.-Very abundant about Matala Island in Khor Dongola, one of the richest pearling shallows. Previously recorded from the Red Sea and East Africa (Tumbatu).

\section{Tubipora purpurea, Pallas.}

The differences between alleged different species of Tubipora remain in a very unsatisfactory stage of definition. Emplasis has been laid, for instance. on the number of pinnule-rows. But our specimen shows with equal clearness polypes whose tentacles have a single row on each side, and polyps whose tentacles have a double row on each side. The difference is in this case due 
to the different degrees of contraction, and is therefore of no significance. We have referred the specimen to Pallas's species, T. purpurea. From this it does not seem to us that $T$. chamissonis can be separated.

Many of the polyps are crowded with spherical or nearly spherical repruductive bodies, most of which show an interual carity and a wall with sever.d layers of nuclei. The following measurements of diameters were taken in uillimetres : $0.0765 \times 0.0765 ; 0.136 \times 0.1445 ; 0.296 \times 0.296 ; 0.323 \times 0.323$ : $0 \cdot 34 \times 0 \cdot 351$. These will form the subject of subsequent study, along with other bodies of a similar nature which occur in sarious Alcyonarians. They are either young embryos or sperm-sacs.

Locality.-Outer edge of the reef (Shabuk). Previously recorded from the Red Sea, from Zanzibar (as T. chamissonis), and from East Indies (as T. chamissonis).

\section{Order II. ALCYONACEA, Verrill.}

\section{Xenia umbellata, Lamarck.}

Numerous colonies with whilish-brown stems and chocolate-brown polyp's. Many of the groups are $50 \mathrm{~mm}$. in height, the stem being about $30 \mathrm{mul}$.. and the polyp-bearing region about $20 \mathrm{~mm}$. A common size of polyp is 10-12 mm., the tentacles and the polyp-body being each 5-6 mm. in length. 'T'he polyp-bodies and tentacles are thickly covered with glistening calcareons vorpuscles. These are arranged in 8 very distinct longitudinal rows on the polyp-body. Every here and there one observes what looks with low power like a perforation about a millimetre in diameter and with a perfectly regular contour. These pore-like spots are dense colonies of zoochlorellie. There are on each side of the tentacles four rows of long pinuules, about 18-20 in each row. There are abundant ova.

While the deseription just given applies to a large number of colonies, there are many others which differ markedly, e. $g$. in being much smaller, in showing no spicules or almost none, in having some reddish colour, in the number of rows of pinnules, in the total number of pinnules, and in the lengtls of the pinnules. After a careful examination of a large number of specimens. we have come to the conclusion that these are all referable to a very variable species.

A specimen from the outer part of Suakim Harbour has a peculiar reddish colour, which Mrr. Crossland noted as "not natural"; but it may be recalled that Klunzinger observed a rusty brown on the inner side of the tentacles. In this specimen the body of the polyp is about $10 \mathrm{~mm}$. in length; the tentacles are about $8 \mathrm{~mm}$. in length; there are slender, elongated, pointed pinnules in 2-3 rows about 12 in each row. There are very abundant zoochlorellæ, and there is not the slightest trace of effervescence when the polyp is dropped into dilute hydrochloric acid. 
In the living colonies there was considerable difference in coloration :a) whitish stems, bluih tentacles, grey pinnules: (b) whitish-brown stems. chocolate-brown polyps; (c) whitish zooids, chocolate-brown tentacles.

Some of the colonies which seem referable to this variable species show only two rows of pinnules on each side of the tentacles, and greatly elongated tentacles appear as if they only had one row. It was easy to find tentacles with three rows of 20 pinnules, or two rows of 30 pinnules. This matter of rows of pinules is a very untrustworthy and useless character. Young polyps oceur at the bases of those fully-formed, and show various stages from minute zooid-like buds on which no tentaeles are visible with low power, to -mall forms with distinct teutacles and pinnules, but only about a tenth the ize of the ordinary polyps. Over and over again we have thonght for a time that we had to do with a clear ease of dimorphism of zooids, but further examination has shown that there were transitions between minute polyp howing no tentacles and others not much larger which exhibited them. IIoreover, in colonies apparently identical in every other respect with tho-e -howing minnte zooils without tentacles, no sneh \%ooids condl be funnd.

Loculities.-Various parts of suakim Harbour, 1-2 fathoms. l'reviously recorded from Red sea, Mozambique, Tumbatu, Zanzibar, Ceylon, Pacitic ()ean (New Britain).

\section{Xevia c.rrclea, Ehrenberg.}

A small specimen growing on a coral fragment presents some difficulty. The polyps are abont $3.5 \mathrm{~mm}$. in height, the tentacles are abont the same. On each side of the tentacle there are $16-20$ pinnules, in 2-3 rows or in one. The two lowest pinnules are small, but it cannot be said that there are two kinds of pinnules. The extended pinnules are elongaterl, slender, and pointed.

The tentacles and the bodies of the polyps show large numbers of zoochlorelle. In some cases the colour remained bright green. Under low power the surfacm had a glistening appearance, as if dusted with refrative particles. These are zooch'orellæ, not spicules. The calcareous corpuscles are very minute and hy no means abundant. The specimen may be referred to Ehrenberg's. . corrulen. ar. what comes almost to the same thing, it may be regarded as a dwarf variety of $\mathrm{X}$. umbellata ${ }^{*}$. In another specimen the number of pinnules un "ach side was 24 in two rows, the whole surface glistened with zoochlorella. anl no effervescence was seen when the polyp was placed in dilute aeid.

Locality._Off S.E. corner of Shubuk, 9 fathoms: bottom of coarse sand. thells, and coral. Etnleh shoals in Suez Bay.

- It seems certain that $\mathbf{X}$. umbellata, Lamarck, $\mathbf{X}$. fuscescene, Ehrenberg, und $\mathbf{X}$. carulea i.hrenberg, are rery closely related. It may be necessary eventually to unite them in os: variable species. 
XeNia fuscescens, Ehrenberg.

Several colonies, showing two sizes of zooids, are referable to this species, which is closely related to $X$. umbellata, Savigny.

The larger zooids hare bodies up to $18 \mathrm{~mm}$. in length, with tentacles about half as long. There are about 40 long slender pinnules on each side, in two rows. There are abundant zoochlorellæ.

The small zooids are $2-4 \mathrm{~mm}$. in height. They show minute tentacles, but no pinnules.

Locality.-Suakim Harbour, $\frac{1}{2}$ fathom. Previously recorded from the Red Sea, Zanzibar.

\section{ALCYONIUM SPHEROPHORUM (Ehrenberg).}

See C. B. Klunzinger: Die Korallthiere des rothen Meeres, Part I. Die Alcyunarien, etc., 1877, p. 22.

W. May, 1899, loc, cit. p. 105.

The collection includes numerous specimens of this common species. In their mode of growth they more nearly resemble $A$, pachyclados, but their spicules are nearest those of A. spharophorum. We see no reason for regarding these as distinct species, and we would suggest the incorporation of the former in the latter.

We are inclined to think that $A$. globuliferum, Klunzinger, A. digitulatum, Klunzinger, and A. brachyclados, Ehrenberg, should be referred, along with A. pachyclados, to one species-A. spharophorum. As described and figured, they do not seem to us to differ in more than slight quantitative characters, which are probably not more than individual fluctuations. The specimens here referred to $A$. spharophorum furnish all the kinds of spicules figured as distinctive of $A$. globuliferum, $A$. digitulatum, and $A$. brachyclados, though the most prevalent agree with those figured as distinctive of A. spharophorum. The colour of the living specimens was "like weak cocoa " with "chocolate" tentacles. This corresponds with Ehrenberg's "polypis fuscis."

Twelve species of Alcyonium have been reported from the Red Sea; but there is no doubt that the list will have to be much reduced.

Locality.-From the coral shoal of Kal el Kebira in Suez Bay. Previously recorded from Red Sea, Madagascar.

SarCoPHytCM GLAUCLM, Quoy et Gaimard. (Plate 5. fig. 5.)

See E, von Marenzeller: "Ueber die Sarcophytum benannten Alcyoniiden," Zool. Jahrb. i. (1886) p. 352 , Taf. ix. figs. 1 \& 2.

The collection includes several specimens of this species.

A typical oolony consists of a stout trunk, $1.5 \mathrm{~cm}$. high by $4 \cdot 7 \mathrm{~cm}$. hroad, somewhat concealed by the overhanging much folded lobes of the capitulum. The upper surface of the capitulum is about $11.5 \mathrm{~cm}$. in breadth, and the appearance presented by the convoluted and dovetailed lobes has been compared to that of a Meandrine Coral. 
The autozooids are large and well-marked. Towards the periphery of the capitulum they are closely aggregated in rows parallel to the free border, the individuals of adjacent rows alternating. Towards the centre of the capitulum they become sparser. A converse distribution of the siphonozooids is to be noted.

Towards the centre the siphonozooids are very numerous; as many as $t$ to 13 can be counted in a straight line between two adjacent autozooids: peripherally only 1 to 3 .

The spicules agree with Marenzeller's figures.

The following measurements were taken of length and breadth in millimetres :-

Cortical spicules from the lobes of the capitulum:

Clubs : $0.22 \times 0.06 ; 0.175 \times 0.025 ; 0.15 \times 0.025 ; 0.13 \times 0.04 ; 0.1 \times$ $0 \cdot 015$.

Rods : $0.35 \times 0.025 ; 0.29 \times 0.025 ; 0.26 \times 0.02 ; 0.21 \times 0.025 ; 0.15 \times$ 0.015 .

Spindles: $0.27 \times 0.03 ; 052 \times 0.03 ; 0.22 \times 0.04 ; 0.17 \times 0.02 ; 0.15 \times 0.02$; $0.075 \times 0.02$.

ipicules from the antozooids :

Rods : $0.28 \times 0.02 ; 0.27 \times 0.02 ; 0.26 \times 0.02 ; 0.25 \times 0.02 ; 0.21 \times 0.01$.

Cortical spicules from the trunk:

Tuberculate spindles : $0.8 \times 0.15 ; 0.8 \times 0.12 ; 0.78 \times 0.16 ; 0.74 \times 0.12$ : $0.68 \times 0.14 ; 0.62 \times 0.12 ; 0.55 \times 0.15 ; 0.5 \times 0.1 ; 0.47 \times 0.075$; $0.44 \times 0.06 ; 0.45 \times 0.075 ; 0.35 \times 0.075$.

Slightly spinose spindles: $0.39 \times 0.04 ; 0.34 \times 0.04 ; 0.32 \times 0.04 ; 0.3 \times$ $0.06 ; 0.15 \times 0.03$.

Clubs : $0.24 \times 0.06 ; 0.2 \times 0.05 ; 0.18 \times 0.05 ; 0.15 \times 0.03 ; 0.12 \times 0.05$; $0.1 \times 0.04$.

Smooth spindles : $0.4 \times 0.04 ; 0.275 \times 0.03 ; 0.23 \times 0.03 ; 0.22 \times 0.02$ : $0.12 \times 0.04$.

The colour in spirit is light to medium brown. Mr. Crossland notes that the colour of the living colonies was greenish brown, but that the tentacles were white in some. Consequently the fully expanded colony, seen from ahove, often appeared white.

Locality.-Suakim Harbour ; growing in proximity to coral, Sherm Shekl. P'reviously recorded from Australia, Red Sea, Tonga Island, Viti Island, Maldive Islands.

\section{Siclerophytum gardeneri, Pratt.}

See E. M. Pratt: "The Alcyonaria of the Maldives," in Gardiner, Fauna and Gengraphy of the Maldive and Laccadive Archipelagoes, ii. (1903) p. 527.

Several specimens belonging to this species illustrate how a colony becomes gradually more complex in its structure with increased growth. A young colony is represented by an elliptical mass $7.5 \mathrm{~cm}$. by $5.5 \mathrm{~cm}$.; from its 
upper surface lobes arise to a height varying from $0.5 \mathrm{~mm}$. to $7 \mathrm{~mm}$. The smaller lobes are wart-like. An older colony, shayed like a half-moon. carries on its convex upper surface several lobes, the largest attaining it height of $2 \mathrm{~cm}$. : these lobes have numerous digitate branches up to $7 \mathrm{~mm}$. in length with a breadth of about $4 \mathrm{~mm}$.

The spicules agree closely with the description given by Miss Pratt Alcyonaria of the Maldives, p. 527), aud consist of clubs which average 1).06 to $0.1 \mathrm{~mm}$. in length by 0.02 to $0.06 \mathrm{~mm}$. in breadih, and spindlex (). 16 to $0.2 \mathrm{~mm}$. in length by $0.06 \mathrm{~mm}$. in breadth.

The tuberculate spicules are about $3 \mathrm{~mm}$. long and 0.8 to $1 \mathrm{~mm}$. broad.

The colour of a colony in spirit is light to dark brown ; during life it was dull ehocolate.

Locality.-Very abundant locally in reef gaps due south of Shubuk. Previously recorded from the Maldives.

\section{Sclerophytum querciforme, Pratt. (Plate 8. fig. 1.)}

See E. M. Pratt, 1903, loc. cit. p. 530.

Several fine colouies of this species are included in the collection. The specimen photographed (Pl. 8. fig. 1) bas a short wrinkled and furrowed trunk, somewhat compressed laterally.

The branches come off rather abruptly from the stem and pass almost imperceptibly into a much branched capitulum.

As the photograph suggests, the colonies tend to be more complex than Miss Pratt's figure (Alcyonaria of the Maldives, pl. xxxi. fig. 33) would lead one to suppose.

The spicules of the capitulum are very varions, comprising tubercnlate spindles similar to those of the trunk though smaller, spinose spindles and clubs.

The following measurements were taken of length and breadth in millimetres :-

Spinose spindles : $0.32 \times 0.03 ; 0.28 \times 0.03 ; 0.25 \times 0.03 ; 0.18 \times 0.02$.

Clubs: $0.23 \times 0.02 ; 0.22 \times 0.03 ; 0.2 \times 0.04 ; 0.18 \times 0.02 ; 0.015 \times 0.04$; $0.14 \times 0.04 ; 0.12 \times 0.03 ; 0.08 \times 0.03$.

The spicules of the trunk are tuberculate spindles, rarely forked, besides clubs and spinose spindles. The tabereulate spicules vary greatly in size, the largest being about $5 \mathrm{~mm}$. by $0.7 \mathrm{~mm}$.

The following arc the mensurements of the colony represented in the photograph :- Breadth of trunk at base, $3.5 \mathrm{~cm}$; breadth of capitulum, s.5 $\mathrm{cm}$. ; height of capitulum, $4.5 \mathrm{~cm}$.

The colour of the colony in spirit is light to dark brown; when alive it was parple-slate. 
Locality.-Off south-east corner of Shubuk, at a depth of 9 fathoms, on a bottom of coarse sand, shells, and coral. Previously recorded from the IIaldives.

Sclerolitytim densum (II hitelegue).

= Lobophytum densum, Whitelegge.

See Th. Whitelegge, "The Alcyouaria of Funafuti," Mem. Australian Mus. 1897, p. 219 , pl. xi. figrs. $4 a-4 h$.

See E. M. Pratt, 1903, loc. cit. p. 521, pl, xxix. fig. 18, pl. xxx. figs, 2022.

This species is represented by two very hard and brittle colonies. The trunk of one colony is $7 \cdot 5 \mathrm{~cm}$. broal and $5.8 \mathrm{~cm}$. high. It passes almost imperceptibly into numerous finger-like processes. What we have observerl in these specimens corresponds closely with Miss Pratt's figures (Aleyonaria of the Maldives, 1903).

Whitelegge (1897) has elassified the spicules very minutely, and his -ubdivisions have been followed in taking the following measurements of length and breadth in millimetres :-

i. Large fusiform, with simple spine-like tubercles and usually with a transverse median constriction : $2.5 \times 0.5 ; 2.1 \times 0.4 ; 2 \times 0.4$.

ii. Large fusiform, subcylindrieal or subelavate, closely tuberculate. the tulereles being thickly studded with minute spiny warts: $3.1 \times 0.5 ; 2.7 \times 0.5 ; 2.3 \times 0.45 ; 1.9 \times 1) .4$.

iii. Smaller fusiform, strongly but distantly tubereulate : $0.75 \times 0.25$; $0.6 \times 0.2$.

iv. Small fusiform, comparatively smooth, but with some spines: $1 \times 0.18 ; 0.48 \times 0.1$.

v. Spindles : $0.22 \times 0.04 ; 0.19 \times 0.04 ; 0.17 \times 0.03 ; 0.06 \times 0.03$.

vi. Clubs : $0.12 \times 0.04 ; 0.08 \times 0.04$.

The colour of the colony in spirit is pale yellow; when living it was hluish-grey.

Locality.-Forms great sheets in about four feet of water in suakim Arehipelago (Tella Tella Seghir Island). Previonsly recorded from Funafuti, China Seas, British New Guinea, the Maldives.

Lithophytum arboreum, Forshil.

For deseriptions, see W. May (1899), loc. cit. p. 134, and W. Kikenthal, "Verstich einer Revision der Aleyonarien. II. Die Nephthyiden, 1 Teil," Zuol. Jahrb. 1903, p. 124.

A large number of specimens are referable to this species. There is eonsiderable variety as regards the dimensions of the spicules, and some forms approach $L$. stuhlmanni.

One of the largest specimens consists of a common basis $7 \mathrm{~cm}$. in breadrl. from which six branches take origin. These bear secondary branches on 
which the polyps are thickly clustered in catkins. A typical branch separated from the common basis corresponds closely to the figure given ly Klunzinger (1877).

In more than one specimen we found no trace of spicules, but as these specimens were badly preserved we suppose that some acid had been accident:llly added to the preservative.

Localities.-Suez; Coral shoal of Kal el Kebira in suez Bay ; Khor Abu Hamama, 10 fathoms, muddy bottom. Previously recorled from Red sea, Zanzibar, New Britain.

LithophyteM BRassicix (1/uy). (Plate 5. fig. 4.)

See W. May, 1899, loc. cit. p. 139, fir. 22. W. Kiukenthal, 1903, p. 120.

We have figured (Pl. 5. fig. 1) a specimen which agrees in essential features with Lithophytum brassicum, though it is somewhat divergent in its mode of growth and general appearance. It is fixed to is piece of Millepore and rises to a height of $20 \mathrm{~mm}$., with a maximnm breadth of $55 \mathrm{~mm}$. It shows about sixty subglobose heads, each bearing about a score of polyps which are deeply retracted. The colour is a dull light brown.

Locality.-Edge of leeward reef, Suakim Archipelago, Tella Tella Kebira. Preriously recorded from Zanzibar.

\section{Lithophytü thitsoides (Ehrentery).}

= Ammothea thyrsoides, Ehrenberg. See W. Kükenthal, 1903, loc. cit. p. 109.

Several fine specimens of this common species are included in the collection. They consist of a common basis from which cylindrical stalks rise parallel to one another. The polyps arise directly from the ends of the stalks. The spicules of the stalks and polyps are very slender transparent spindles with few warts.

The following measurements were taken of length and breadth in millimetres :-

(a) Polyp-spicules : $0.3 \times 0.01 ; 0.28 \times 0.01 ; 0.2 \times 0.01 ; 0.15 \times 0.01$; $0.12 \times 0.01 ; 0.1 \times 0.1 ; 0.05 \times 0.01$.

(b) Stem-spicules: $0.46 \times 002 ; 0.37 \times 0.02 ; 0.35 \times 0.02 ; 0.27 \times 0.02$; $02 \times 0.01$.

The colour of the preserved specimens is yellowish-brown; in life they were dull brown.

Locality.-Outer Park of Suakim Harbour. Previously recorded from Red Sea, Indian Ocean (Tumbatı), Zanzibar.

LithOPHYTLM CROSSLANDI, n. sp.

A common stem, $2 \mathrm{~cm}$. broad and $1.5 \mathrm{~cm}$. high, gives origin to four limp branclies showing longitudinal furrows. These branches are 13,12, 9, and $i \mathrm{~cm}$. in length respectively, and carry secondarr branches on which the $[56]$ 
polyp-hearing twigs are clustered. The polyp-bearing twigs are in the lorm of catkins with a length of from 0.5 to $1.5 \mathrm{em}$. The basal eatkins are stouter and more elosely beset with polyps than the upper.

A notable diagnostic feature is the presence of rows of closely aggregater small granular spicules in the tentacles, and continued on to the polyp-hend and polyp-stalk.

More spicules are to be found in the cortex of the stem than in the cortex of the main branches; consequently the stem is somewhat more rigill. The spicules of the cortex include spindles with large spines; the spindless are sometimes curved, and the spines are in some cases longer on the convex surface; there are also spindles with few warts, irregular spinose bodies and bicuspids, i.e. with two prongs or eusps.

The following measurements were taken of length and breadth in millimetres :-

Spinose spindles : $0.72 \times 0.2 ; 0.55 \times 0.13 ; 0.52 \times 0.1 ; 0.45 \times 0.1$ : $0.37 \times 0.12 ; 0 \cdot 33 \times 0.15 ; 0.29 \times 0.12$.

Spindles with few warts : $0.42 \times 0.05 ; 0.375 \times 0.1 ; 0.37 \times 0.1 ; 0.335 \times$ $0 \cdot 075 ; 0 \cdot 35 \times 0 \cdot 1 ; 0 \cdot 29 \times 0 \cdot 03 ; 0.25 \times 0.1 ; 0.23 \times 0 \cdot 05$.

Bicuspids : $0.47 \times 0.275$.

The canal walls eontin highly spinose spindles, spindles with small warts, highly spinose club-shaped bodies, irregular spinose bodies, and bicuspids.

The following mensurements were taken of length and breadth in millimetres :-

Highly spinose spindles (the spines being larger on the convex side): $0.52 \times 0.12 ; 0.4 \times 0.075 ; 0.37 \times 0.11 ; 0.35 \times 0.1 ; 0.3 \times 0.1$ : $0 \cdot 3 \times 0 \cdot 15$.

Spindles with small warts: $1.02 \times 0.22 ; 0.95 \times 0.2 ; 0.85 \times 0.175$ : $0.52 \times 0.12 ; 0.32 \times 0.1$.

Highly spinose eluh-shaped bodies: $0.32 \times 0.15 ; 0.275 \times 0.175$.

Bieuspids : $0.42 \times 0 \cdot 175$.

Mr. Crossland notes that the specimen appeared whitish under water, fate brown when brought up.

Lecality.-From a depth of three or four feet in the Coral-resf of Khor Delaweb.

Lithophyтuм мacrobriculatum, n. sp. (Plate 8 . figs. 2 \& 3.)

From a stem rather less than $1 \mathrm{~cm}$. high, with a breadth of $2.5 \mathrm{em}$. three primary branches take origin. One of these, after a course of half : centimetre, divides dichotomonsly into two branches of 4 and $5 \mathrm{~cm}$. in length respectively. The other primary branches are 6 and $4 \mathrm{~cm}$. in length.

l'olyps are not borne either on the main stem or on the main branches, but [57] 
on secondary branches and the twigs which spring from these. The secondary hranches are crowded elosely on the primary and form catkins 15 to $2 \cdot 5 \mathrm{~cm}$. in length, the larger catkins being of a compound claracter.

In the cortex of the terminal polyp-bearing branches there is a longitudinal arraugement of the spindle-shaped spienles, and this is continued on to the dorsal surface of each polyp-stalk.

The polyp-heads are bent sharply on the polyp-stalks, so that the tentacular. surface faces the cortex of the terminal twigs.

The cortical spicules of the stem and main branches form by interlacing a continuous armature. These spienles are of very diverse aril distinctive forms, inclnding the following :-

(a) Boat-shaped spindles with few warts.

(b) Curved spindles with long spines, which are more developed on the convex surface.

(c) Very spinose elub-like forms.

(d) Triradiate spinose bodies.

(e) Irregular spinose bodies.

The followisg measurements were taken of length and breadth in millimetres :-

(a) Boat-shaped spindles : $0.8 \times 0.15 ; 0.75 \times 0.075 ; 0.67 \times 0.1 ; 0.62 \times$ $0.1 ; 0.5 \times 0.075 ; 0.45 \times 0.09$.

(b) Curved spindles : $0.95 \times 0.15: 0.85 \times 0.12 ; 0.8 \times 0.15 ; 0.73 \times 0.15$; $0.7 \times 0.1 ; 0.65 \times 0.15 ; 0.52 \times 0.13 ; 0.5 \times 0.1$.

(c) Club-like forms : $0.33 \times 0.25$.

The spicules of the polyp-head and polyp-stalk include long curved or sinuous spindles with knob-like warts which in some cases are more numeroue and better dereloped at the tips of the spindles; also spindles with only a few poorly developed spines.

The following measurements were taken of length and breadth in millimetres :-

(1) Spinose spindles: $1.5 \times 0.1 ; 1.15 \times 0.1 ; 1.1 \times 0.12 ; 0.6 \times 0.05$ : $0.4 \times 0.05 ; 0.2 \times 0.02$.

(2) Smooth spindles with only a few spines: $1.2 \times 0.09 ; 0.9 \times 0.05$; $0.69 \times 0.05$.

The spicules of the canal walls consist of spindles similar to those of the cortex, but the form with few spines predominates.

The following measurements were taken of length and breadth in millimetres :-

(1) Spinose spiudles : $0.87 \times 0.12 ; 0.85 \times 0.12 ; 0.83 \times 0.12 ; 0.6 \times 0.1$; $0.55 \times 0.13 ; 0.5 \times 0.1$.

$[58]$ 
PROF. THOMSOX AND MR. MCQUEEX-RFPORT OX THE ALCYOSAKIANS.

2) Smooth spindles with only a few spines: $1.02 \times 01.5 ; 0.72 \times 0.1 \mathrm{i}$ : $0.6 \times 0.075 ; 0.55 \times 0.075 ; 0.42 \times 0.1 ; 0.4 \times 0.05: 0.275 \times 0.014$; $0.2 \times 0.05$.

The colour of the colony in spirit is light yellow.

Locality.-Khor Itongola.

\section{Nephthya zaxzibarexsis, Thomson and Henderson.}

See Thomson and Henderson, 1906, loc. cit. p. 421, pl, xxvii, fig. 3.

A specimen which seems to be referable to this species difiers from thi. type in being distinctly more rigid; that is to say, more densely filled with spicules.

Locality.-Engineer Island, Khor Dongola. Previously recorded from Trasin Channel, Zamzihar.

\section{XEPHTHYA ALBIDA ( $/ 1$ olm .}

$=$ Spongodes albida. Holm.

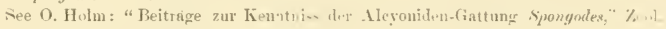
Jahrb. viii. (189.-) p. 30, 3 figs

See Kükenthal, 1903, he. cit. p. I60.

A specimen which scems referable to this species differs from the type in having the polyp-body covered with very numerous small sjicules without definite arrangement in double rows. In other words, the larger poly 1spicules arranged in chevron are not represented. In inclnding Nephthya jagerskioldi with Spongodes savignyi, Kiikenthal notes the same kind of variation which we believe to have occurred here, namely a replacement of fewer larger spicules on the part of the polyp-wall by more numerous smaller spicules. This cannot be regarded as of systematic importance.

Lorality.-Suakim Harbour. Previously recorded from the Red Sea.

\section{SPONGODES * HEMPRICHI, KTunzinger.}

See Klunzinger, 1877 , loc. cit.

Kükentbal, 1904, loc, cit.

Kükenthal: "Versuch einer Rerision der Alcyonarien. II. Die Familie der Nephthyiden, 2 Teil," Zool. Jahrb. xxxi. (1905) pp. 503-726, 7 pls. \& 61 figs.

Several colonies in the collection are evidently referable to a group of siecies which Kükenthal speaks of as closely allied, namely, s. hartmeyeri, S. mayi, S. klunzingeri, S. ehrenbergi, and S. hemprichi.

- According to Kükentbal, the generic name Spongorles should be replaced by another and he siggests Dendronephthya; see page 74 . 
I. The specimens differ superficially from $\$$. hartmeyeri:

1) in being much more ramified and crowded colonies;

2 ) in the absence of any trace of foliate lower branches;

(3) in their colour-scheme, which is due to the thick covering of crimson spicules. As to the colour of the living specimen. Mr. Crossland notes that it appeared jet-black when seen through a fathom or two of elear water, but when brought up it showed a splendid dark crimson, shading into pink on the stem.

They differ more intimately in the following points :

(i) The anthocodial spicules are arranged in 8 rows of $5-7$ converging pairs; they converge but slightly and are more or less longitudinal in S. hartmeyeri. YLoreover, the uppermost spicules of the double rows do not project beyond the anthocodia as they do in S. hartmeyeri.

(2) The tip of the main "Stiitzbiindel" spicale is smooth, while in S. hartmeyeri the same spicule is most spinose towards the free tip.

3) They differ in the dimensions and direction of the spicules in the cortex of the main branches. In $S$. hartmeyeri the cortex is densely filled with large, very thick, finely spinose spindles up to $5 \times 0.5 \mathrm{~mm}$. They seem from the drawing to be longitudinally arranged. In the specimens in this collection the spindles are for the most part arranged transversely to the long axis of the branches.

The following measurements of these spindles were taken in length and breadth in millimetres: $2 \times 0.12 ; 1.8 \times 0.1$ : $0.65 \times 0.05$.

II. The specimens differ superficially from $S$, mayi:

(1) in the absence of the rigidity and brittleness characteristic of a species developed in one plane. The colonies in this collection have a well-developed bare trunk up to $7.5 \mathrm{~cm}$. in length. In one specimen the stem divides sonewhat dichotomously into two main divisions; in another specimen, four main branches take origin abruptly. Fron the main branches secondary branches arise in every plane.

(2) The branching is more profuse and the clusters of polyps are much denser than in $S$. mayi.

(3) The colour-scheme is golden yellow in S. mayi.

They differ more intimately from S. mayi:

(1) in the absence of a greatly developed projecting spicule at the end of each double row of spicules on the anthocodiæ;

[60] 
(2) in the fact that only one "Stiitzbiindel" spicule projects beyont the polyp-head; the tip of the "Stiitzbiindel" spievles is smooth. like that of the ehief "stiitzbindel" spicnles in S. mayi ;

(3) in the disposition of the superficial eortical spicules, which ar. predominantly longitudinal in S. mayi; and

(4) in the character of the spicules of the cortex, which are eurved spindles, while in $S$. mayi there are, in addition to spindles. elubs, four-rayed spieules, and irregular bodies.

11I. The specimens differ superficially from S. klunzingeri :

(1) since that speeies is for the most part developed in onc plane witl an almost suppressed trunk ;

(2) in the mode of branching and in the disposition of the poly"n in crowded bundles of 6-11 in each bundle, whereas in S. klunzingeri they are only $1-3$ in a humblle.

They differ more intinately :

(1) in the nature and arrangement of the anthocodial spicules, which in s. klunzingeriare in rows of $8-10$ with the uppermost two very much longer ;

(2) in having an entirely different "Stützbündel" made usually of two spieules; and

(3) inasmuch as the spicules of the canal-walls are broad and flat spinose spindles.

In the speeimens the spicules of the camal-walls are varied and may

be grouped as follows:

(A) spindles of undulating eontour, or halfmoon-shaped, or tending to be elub-shaped;

(B) spindles forked at one end (bicuspids), transitional to triradiates ;

(C) triradiate forms;

(D) irregular bodies with four arms, probably derived from (:. All spinose.

IV. The colonies have a great superficial resemblance to $S$, ehrenbergi, but differ from it in having 6-11 polyps in each bundle, while S. ehrenbergi has 5-8.

They differ more intimately :

(1) inasmuch as $S$. ehrenbergi has only $4-5$ pairs of spicules in each double row, each abont $0.3 \mathrm{~mm}$. in length, the uppermost $0.5 \mathrm{~mm}$. with long oblique spines;

(2) in the nature of the projecting spieules of the "Stiitzbiindel," which in S. ehrenlergi has a spinose tip, whereas in thesu specimens the tip is smooth ; 
(3) in the spicules of the cortex of the main branches, which do not include any elubs or oval spinose bodies;

(4) inasmuch as from the canal-walls of S. ehrenbergi only spindles are reported,

V. The specimens agree with S. hemprichi in the following respects:

(1) There are $5-7$ pairs of anthocodial spicules in each donble row and the uppermost pair project very slightly. It is to be noted, however, that the number of paired spienles on the two rows on the rentral surface of the polyp-head mas be as few as two pairs.

(2) The projecting spicule of the "Stiitzbindel " has a smooth tip".

(3) The spicules of the canal-walls are, on the whole, similar. In $S$. hemprichi there are curred spindles, triradiates, and small bodies beset with sereral prongs.

(4) The spicules of the cortex are arranged transrersely.

(5) The polyp-spicnles are bloot-red and the polyps yellowish.

The only difference between Crossland's specimens and those described wy. Kükenthal lies in the general architecture, which is well represented ly Kiikenthal's drawing of S. ehrenberyi. They may be referred to the irliorescens type of S. hemprichi, which Kükenthal describes as transitional hetween the glomerate and the divarieate mode of branching.

Another specimen which is superficially very unlike the above, but elosely resembles Klünzinger's figure of Sponyodes hemprichi, is in its details so like what we have deseribed that we cannot but refer it to the same species, which, therefore, includes two distinct modes of growth-that figured by Klunzinger and the arborescens type of Kükenthal.

A case like this leads us to feel the precariousness of a classification which attaches much importanee to modes of branching.

Locality. - Shab Baya, near Rawaya. Previously recorded from Red sea.

\section{SPONgODEs hartueyeri, Wiilienthal.}

Two small rigid whitish colonies seem to be referable to this species, but differ in having no coloured spicules and in having rongher "Stiitzbüudel" -picules. They are probably young colourless forms.

Locality.-Khor Dongola. Previously recorded from the Red Sea.

\section{SPONGODES SUeslaya, n. sp. (Plate 5. fig. 1.)}

A brownish-yellow interesting colony of apparently glomerate type. It resembles in general architecture Kükenthal's Spongodes (Dendronephthya) clarata (see Versuch einer Revision der Alcronaceen. Die Neohthriden, 2te Teil, 
Taf. 26) : but in the nature of the projecting "Stützbündel" spindle and in the number and arrangement of the spieules on the anthocodia it closely. approaches $S$. mayi. It seems to belong to the group of allied species referred to under S. hemprichi.

There is a somewhat flattened flexible stem, longitudinally furrowed. $8.5 \mathrm{~cm}$ in length and $1 \mathrm{em}$. in breadth. The eortex of the stem shows well-nurkel transverse striations due to the underlying spindles.

Small polyp-hearing twigs spring from the stem, somewhat sparsely below. more thickly above, so that the apex of the stem is completcly hidden by polyp-bundles.

From the stem there arise at irregular intervals secondary loranclies whose length decreases in a somewhat graduated fashion. The following measurements of the length of the various branches from below upwarls on the stem serve to indicate this feature: $2 \mathrm{~cm} . ; 1.75 \mathrm{~cm} ; 1.5 \mathrm{~cm}, ; \mathrm{I} \mathrm{em}$. Thes secondary branches bear nolyp-bearing twigs in thick clusters. The polypare in bundles of from 6 to 12 or even more.

The "Stützbündel" consists of 2 to 4 spindles, one of which projict$0 . t \mathrm{~mm}$. or more herond the anthocodia. This spindle is spinose below with a smooth tip. Of the projecting "Stütabündel "spieules, which are generally. of a yollow colour, the tollowing measurements were taken (length and breadih in millimetres) : $-2 \cdot 3 \times 01 ; 2 \cdot 4 \times 0 \cdot 1$. The tip is smooth for $0.35 \mathrm{~mm}$.

On the anthocodia there are eight double rows of conserging spicules with from 6 to 9 in each row. One spienle of the nppermost row, or oceasionally both, may project for $0.2 \mathrm{~mm}$. beyond the anthocodia. Thus Kükenthal's figure of an anthocodia of S. mayi (see Ueber einige Korallentiere des roten Bleeres, Taf. v. fig. 20) exactly represents what may be seen occasionally in this species, except that only one projecting "Stützbündel "spicule is the rule and not two as figured.

When both spicules of the uppermost row project, they lic atmost parallel to each other in sharp contrast to the pairs below, which converge at a right or a slightly ohtuse angle.

The tentacles are withont spicules. The colour of the anthocolial spicules ranges from $r \in d$ to yellow.

'The spicules of the upper cortex consist of spindles, clubs, bienspids, with an occasional triradiate form. They are very spinose, not merely along the margins, but on every surface; and are colourless or tinged with yellow.

The following measnrements were taken of length and breadth in millimetres :-

Fipindles : $1.7 \times 0.1 ; 1.4 \times 0.1 ; 0.95 \times 0.075 ; 0.8 \times 0.05 ; 0.75 \times 0.075$; $0.7 \times 0.075 ; 0.6 \times 0.05 ; 0.5 \times 0.05: 0.25 \times 0.02$.

Ciuls : $0.75 \times 0 \cdot 1 ; 0.4 \times 0 \cdot 1$,

Bieuspids : $0.6 \times 0.075$.

T'riradiates: cach arm, $0.3 \times 0.2$. 
The spicules of the low. a.stex do not differ from those of the upper 1.rtex in form or colour.

The tollowing measurements were taken of length and breadth in milliunctres :-

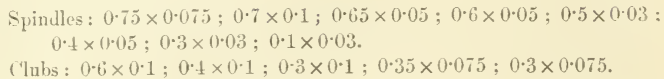

The canal-walls are without spicules.

Some other specimens agreed with the above in general structure, in the nature of the "Stiitzbündel," in the armature of the anthocodia, in the spicules of the cortex, and so on. Thus one could not but admit that all the colonies belonged to the same species, and yet it was impossible to say that the polyps were really grouped in bundles, which is one of the diagnostic features of the genus Spongodes. In some cases they were arranged on a terminal branch in a catkin-like or spike-like mamner. This was the rule in one specimen.

It may be noted that Kiikenthal admits that certain specimens were intermediate in this respect between Spongodes and Tephthya, and consequently difficult to place.

The point to be noted in these colonies is that, though obriously all of the same species, yet they differ in a generic feature:

If we take a composite view of all the specimens this species combines the characteristics of both Sponyodes and lephthya. Tet the colony deseribed in detail must be placed in the glomerate division of the genus Spongodes, Within that division it seems to represent a new species.

Locality.-Suez Bay.

SipoNgodes pharonis, n. sp. (Plate 5. figs. 2 \& 3.)

Several colonies of the umbellate type, agreeing with Kïkenthal's mbragroup in having branches of approximately equal length, with the upper surface practically even. They differ from any of the species of Spongodes hitherto described from the Red Sea-viz. : S. sarignyi, S. hemprichi, S. klunzingeri, S. arborea, S. mayi, S. hartmeyeri, and S. ehrenbergi-in possessing the following combination of diagnostic characters :-

a. The umbellate development of the colony.

b. The absence of spicules on the tentacles.

c. The absence of spicules in the canal-walls.

d. The occasional presence of a strongly developed spine or sometimes of two spines projecting prominently beyond a corymb of polyps, greatly exceeding in diameter and in length the "Stützbündel" spicule or spicules which project beyond the anthocodia of each polyp. 
The colonies show in each casc a substantial trunk which at a distan $\cdots$ of $2.5 \mathrm{~cm}$. or less from its base is enbracud by a collar of foliate lower branchus. These leaf-like branches bear sessile polyps scattered round their nurgin. while further on the upper surface may be seen twigs, which divide in the corymbose fashion characteristic of the whole colony. These twigs al to carry polyps on their tips.

From the angle between the rising stem and the collar spring one or twe hranches equal in size to those that are terminal. These branches in their turn break up into terminal corymbs. Beyond the collar, the stem after : short eourse divides into two or three main branches, which soon divide II, into secondary branches supporting the terminal corymbs. The terminal corymbs are all hrought more or less to the same level, so that the upper surface of the polypurium is somewhat flattenerl. A polyp-bundle ustally comprises 3 to 8 in liviclual polyps, bnt the number is very variable.

The polyp-heal is bent more or less at a riglit or an acute angle to the

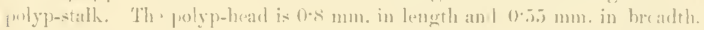
The polyj-stalk is ahout $1 \mathrm{~mm}$. in lengtb. The antho orlial spirules are in rows of 3 to 5 pairs, the uprermost of which do not proje-t heyond the. authocorlia.

The angle of wach cherron is a very acute one, giving a somewhat lonetminal direction to the suicules of the anthocoslia.

Fome variation in colour is to be noted in the anthocorlial spricules. In on. of the e lonis they are colourles, in another red, while transitional pinkisls spicules are present in a third colony. In the "Stützbündel" there may be one or two projecting spicules. These spicules show very small serrations regularly disposed. Their tip may be quite smooth or with an ocensional serration. Their colour varies from a light yellow to a redish yellow.

The following measurements were takmin of thrse spicules (length and liremlth in milimetres) :- $1.5 \times(1.0) 3 ; 1.2 .5 \times 0.1 ;(1.8 \times 0.03 ; 0.7 \times 0.03$. In some of the colonies the size of the projecting ". Stiitzbiundel " spicules ap rewaches nearer to the dimensions of the stout spines which are a feature of thir terminal eorymbs. These strong sjune, which seem to protect and support the polyj, on a terminal corvmb, frencrally arise independently of a? individual polyp, but sometimes ther simply take the place of the normal hut smaller "Sitüztrünte-" "spicule.

()f these stouter spindles the following measmrements were taken (length and brealth in millimetres) : $-4 \times(1.25 ; 4 \times(1.2) ; 3.5 \times 0.15 ; 3.5 \times 0.125$. The tentacles are oblong with a few pimmle and without spieules.

The eortex of the upper branches contains slightly curved spindles with ‥r. fine and regularly disposed serrations.

Thr following measurements of these spindles were taken (length and benulth in millimetres):- $-1 \times 0.2 ; 3 \cdot-2 \times 1) \cdot 1: 1.1 \times(1.5): 1 \times 0.03$. Their robur in ose specinen is white with a yellowish tinge, in three specimens 
resl, but amongst the red spindles are some with intermediate light-pink shates.

Their distinctive feature lies in the remarkably fine serration of the edges of the spindles. This is a constant feature no matter what their dimensions or colour may be.

The lower cortex contains markedly spinose irregular bolies, often somewhat star-shaped, very spinose spindles, spinose clubs, spinose triradiates, - pinose bicuspids.

The following measurements were taken of length and breadth in millimetres :-

Spinose spindles : $1 \times 0.1 ; 0.75 \times 0.1 ; 0.4 \times 0.12 ; 0.33 \times 0.1 ; 0.3 \times 0.11$; $0.25 \times 0.1 ; 0.23 \times 0.075$

Spinose triradiates : $0.5 ; 0.33 ; 0.3=$ length of the three arms.

Spinose bieuspids : $0.75 \times 0.1$.

Spinose elubs : $0 \cdot 18 \times 0 \cdot 13$.

The canal-walls in every specimen are witbont spicules.

The colour of the colonies in spirit varies somewhat, the colour depending on that of the spicules. Where the spicules are red, the colony is reduish; where there are a considerable number of white or light yellow spieules, the colony is proportionately lighter in tint.

Locality.-From a muddy bottom, at a dejth of 12 fathoms, Mersa Abu Hamama, Sudan.

Order III. PSEUDAXONIA, G. rou Kooch.

Melitodes coccinea (Ellis) (= Isis cocoinea, Ellis). (Plate 6. figs. 1 \& 2.)

The collection includes numerous specimens which are referable to Ellis's 1sis coccinea. From Ellis's figure and description there can be almost no doubt that he referred to forms like the present specimens, which must, however, be referred to the genus Melitodes.

The specimens are of a brilliant crimson or scarlet colour, and there is one yellow fragment. The most frequent mode of branching is that figured by Ellis, - a broad fan, with dichotomous branches almost all in one plane, and without anastomosis. In other specimens, howerer, the branches do not spread out in a broad fan, and anastomosis is frequent. The colonies stand erect, reaching a height of $4 \mathrm{~cm}$. and a breadth of $2-4 \mathrm{~cm}$. In some cases colonies grew so elose to one another that their bases formed a continuous sheet. Solitary colonies show most elearly the typical fan-like form.

The internodes, which curve slightly in different planes, vary in length from 5-10 mm. The nodes are very short, $1-2 \mathrm{~mm}$., and are not distinctly marked in the intact colonies. On the thinner twigs the verruce are mostly along the edges, and a somewhat flattened appearance thus results. On the 
thicker branches they occur practically all over. They stand out somewhit prominently io a height of about $0.5 \mathrm{~mm}$, and appear as widely open craterlike elevations or as rounded hillocks according to the state of contraction.

The whole surface of the colony is seen under the lens to be rough witl spindle-shapert spien'es, all of a red colour.

The spicules of the eonenchrma are: (1) substantial tuberculate spindles, of which the following measurements were taken:- $0.3 \times 0.07,0.27 \times 6.09 \mathrm{~mm}$. The tubercles are large and blunt. In some eases the ends of the spindles are irregularly bificl. There are also some slender eurred tuberculate spindles. (2) Short compact fusiform types corered with numerous blunt tubercles: $1.124 \times 0.05 \mathrm{~nm}$. (3) Club-shaped forms or "Stachelkeulen" with irrrgularly shaped tuberenlate heads. From these through torch-like forms ther. are transitions to irregular spindles. The clubs are frequently $0.23 \mathrm{~mm}$. in

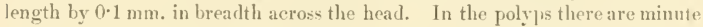
and slender red spindles, besides a number of minute sliglitly tuberculate eurved rodlets which are practically colourless. For both of these typer a common length is $0.04 \mathrm{~mm}$. The ahoral surfice of the tentacles bears about 5 large real spicules arranged in chevron. The axis shows longitudinal canals.

Lowality.-From the siles of a buoy in suez Bay, and on the coral-reel of Engineer I-land, Kilior Dongola.

\section{IIelitudes splexdexs, n. sp. (Plate 7. figs. 1 if 2.)}

Numerous broken pieces of a bright orange-red Melitodiul. They seen to represent several colonies. The nature of the spienles and the presence ol longitudinal canals in the axis indieate the genus Melitodes, but we have not been able to refer the specimens to any of the numerous previously described species.

One of the pieces has a breadth of $6 \mathrm{~mm}$. across an internode abont $3 \mathrm{~cm}$. above the base, while a node about the same height has a breadth of $9 \mathrm{~mm}$. The length of the internode at this level is $11 \mathrm{~mm}$, and towarls the base the colony the internoles have an average length of about $12 \mathrm{~mm}$. Th brancling is profuse, with many anastomoses, but is mainly confined to one plane. An attempted reeonstruction of the broken specimens leads one to infer that the colonies may have been about $25 \mathrm{~cm}$. in height. The terminal branches are about $1 \mathrm{~mm}$. in thickness.

The verruex are almost confined to one surface of the branches. They arm somewhat seattered on the basal parts, but towards the ends their bases are in contact. They are slightly flattened hemispheres. The retracted poly' is just seen as a whitish spot on the top of the verruca.

The axis shows numerons longitndinal canals in the nodes and internork... A thin section throngh a thick internode showed about ten. On the surface of the axis there is external fluting corresponding to the course of the canal= in the ennenchrma. 
The spicules, which are mostly yellowish, include :-

(a) Narrow tuberenlate spindles of various sizes. e.g. $0.15 \times 0 \cdot 018 \mathrm{~m} \cdot$. $0 \cdot 108 \times 003 \mathrm{~mm}$.

(b) Short broad spindles with tubereles at each end and in two when! between, e.\%. $0.04 \times 0.02 .5 \mathrm{~mm}$.

(c) Fusiform types intermediate between ( $u$ ) and (li) with shar! tubercles

(1) A few non-foliate clubs, e. $q .0 .055 \times 0.028 \mathrm{~mm}$. across the heat.

(e) Some pale yellow or almost colourless rods, sometimes almosi straight and smooth, often with a median prominence on each side, often slightly curred at the ends, e.q.0.096 $\times 0.012 \mathrm{~mm}$.

The generic distinetions of the Melitodide are not very satisfactory, hut we may note that the absence of foliaceous clubs, the presence of some small nodular spicules in the cortex, and the canals in the axis point to Melitodes.

Locality.-Mersa Abu Hamama, from a muddy lottom, at a depth of 10 fathoms.

* ('lathraria rtbrinodis, Giruy. (Plate 6. figs. 3 \& t.)

See Gray: Proc. Zool. Foc. London, 1859, p. 486 ; Catalogue of Lithophytes in thit British Museum, 18i0, p. 11, 1 fig.

=.Mrpsea bicolor, Külliker, Icones 11istologice, p. 142, 1 fig.

It is interesting to find in this collection the peculiar Melitodicls to which (iray gave the names Clathraria mbrinodis and $C$. acuta. It is rather remarkable that such striking forms have not been more frequently colleeted. Apart from Gray's bricf deserijtions, we have found no reference to Clathraria.

The larger species, C. mulninodis, is represented by a specimen about $12 \mathrm{~cm}$. in height, which was probably the upper part of a large colony. This is suggested by the size of some of the fragments found in the same ressel.

The branching is mainly in one plane, and there is abundant anastomosis. The branches arise almost invariably from the nodes. There is a strong tendency to dichotomy, and the two branches diverge at a wide angle at their common origin. This gives a very characteristic appearance, which is increased by the fact that each of the cylindrical branches is of uniform width throughout its length, and terminates bluntly, or may, indeed, be slightly thicker at the tip than at its origin. The smaller twigs show a much os marked tendency to dichotomy, and some of them narrow towards the

* The account of C'atheraria rubruodis and $C$ : acuta was prefared by Miss Doris $\mathrm{L}$. W.akumon as part of a thesis for the degree of B.Sc. in the Cnirersity of Aberdeen. 
mul, which is alwars truncate. The stauter branches have a diameter of $4 \mathrm{~mm}$. ; the more slender twigs of $2 \mathrm{~mm}$.

The preserved specimens have a dirty eream-colour, frequently tinged with pale snlphur-yellow along one sicle of a branch and near the tips of the twigs. In the lising specimens the colonr was bright light yellow, with dull red joint:. The specific name rubrinodis has referenee to the dark-red horny nodes, which shine indistinctly through the whitish cœenenchyma, or appear as bright red patehes where a branch has been broken away.

The internodes are of rery unequal lengths, varying from 7 to $32 \mathrm{~mm}$. : the ealeareous axis, stripped of cœenenchyma, has a diameter of 1-3 $\mathrm{mm}$. and is white with a tinge of sulphur-rellow here and there. The longer branches may have as many as seven internodes; the shorter branches and the twigs consist of only one piece.

Fig. 1.

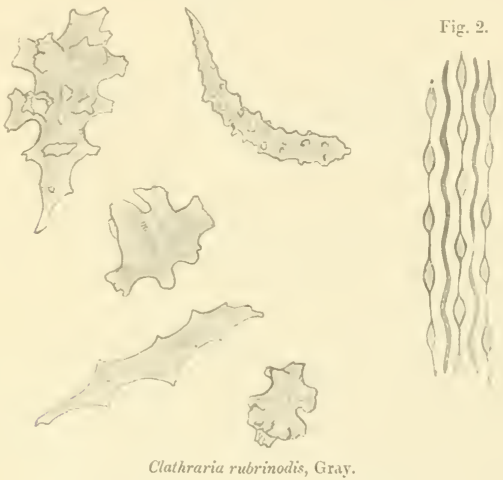

Figr. 1. Spicules. Fig. 2. Details of calcareous joints.

On the surface of the white calcareons axis there is a characteristic seulyturing due to longitudinal furrows. There are two sets of these furrowwhich alternate with one another. One set is deeper than the other and of -yual width thronghout. The shallower furrows are constricted at regular intervals, and the broad portions of one sballow furrow lie between the constrictions of the similar furrow on either side. In these broad orals the jolyps appear to be set. 
There are no nutritive eanals in the axis. A longitudinal section shows that the axis is built up of minute spindle-shaped spieules, fused together, and arranged with their long axes in the line of the long axis of the linanch.

The nodes are much shorter than the internodes (3-4 mm.) and are somewhat thicker. They are composed of a dark-red horny substance, which, under the microscope, appears as a yellowish network with numerous reil spindle-shaped spicules in the meshes.

It occasionally happens that a hranch arises from an internode; in such cases the first joint is horny.

The crean-coloured coenenchyma is crowded with small spicules. Mlost of these are white, hut some are tinged with yellow or yellowish green. Spiny clubs and more warty double-clubs and dumb-bells are very abundant. spindles bearing numerous very minute warts are less common, and simple spindles are rare.

The following measurements were taken of length and breadth in millimetres :-

Clubs : $0.136 \times 0.084 ; 0.153 \times 0.059 ; 0.119 \times 0051$.

Double elubs: $0.042 \times 0.034 ; 0.067 \times 0.055 ; 0.051 \times 0.042$.

Spindles : $0.187 \times 0 \cdot 051 ; 0.119 \times 0025$.

Red spindles of nodes: $0.102 \times 0.017 ; 0.085 \times 0.017 ; 0.068 \times 0.002$,

The small polyps are spirally arranged almost uniformly all round the branches. They are nearly all retacted, lying almost flush with the surface of the eøenenchyma. Besides the substantial anastomosis, there may be a more superficial fusion of conenchyma when one branch lies against another.

Locality.-Coral-reef, Mersa Makdah, Shubuk.

\section{Clathraria acuta, Gray. (Plate 7. figs. $3 \&$ 4.)}

See Gray: Catalogue of the Lithophytes in the British Museum, 1870, p. 12 .

This species is represented by two specimens, one of $7 \mathrm{~cm}$. and the other of $5 \mathrm{~cm}$. in height. The mode of growth is tree-like and graceful. The branches, much more slender than in C.ruhrinodis, are eylindrical and of very uniform width until elose to their end, when they narrow abruptly into a sharp apex.

In the larger specimen there is a main stem, which gives off two long branches on one side, two long and three short on the other, and then bifurcates at the top. The side branches also show dichotomy. Of the seven branches four arise from the internodes. The other specimen is branehed dichotomously throughout and the branches arise from the nodes. On the whole the branching is in one plane. There may be fusion of branches, but not nearly to the same extent as in C. rubrinodis.

The colour of the preserved specimens is a delieate flesh-pink, marked by $[70]$ 
darker red patehes where the nodes shine through the semi-transparent coenenchyma. The living colonies were pink.

The calcareous internodes vary from $10 \mathrm{~mm}$. to $17 \mathrm{~mm}$. in length, and are about $2 \mathrm{~mm}$. in diameter They are marked longitudinally by sinuous. furrows which expand at intervals into little romd pits. The eolour of the axis sharles from deep rosp-red to pink.

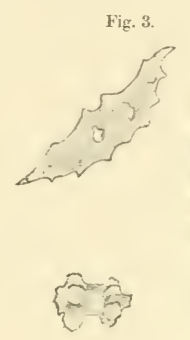

Fig. 4.
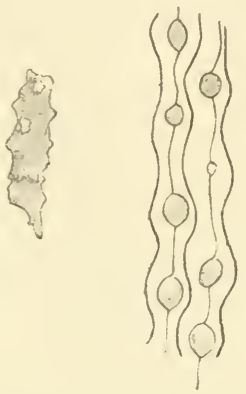

Clathraria acuta, Gray.

Fig. 3. Spicules, Fig. 4. Details and ornament on calcareous joints.

Microscopic examination shows that the axis is composed of numerous spindles fused together, with their long axes in line with the long axis of the branch. The nodes are dark red, much shorter than the internodes, and slightly swollen; they are composed of a yellowish horny network enclosing short red spindles.

The pinkish-white cœenenchyma is semi-transparent and very delicate. The polyps are not nearly so numerous as in $C$. rubrinodis, but are larger in proportion and project from the surface as minute warts. They seem to correspond in position to the cup-shaped pits in the axis of the internodes, and their arrangement is very markedly spiral.

The spicules of the cœnenchyma are spiny and tuberculate elubs and warty double-clubs with a few spindles and boomerangs. They are, on the whole, rather smaller than in C. rubrinodis and distinctly less spiny. The majority are colourless, but many show a red or pink tinge.

Locality.-Khor Dorgola, near the group of Islets; rock botton, $9 \frac{1}{2}$ fathoms. [71] 


\section{Note on the Giemus Clathraria, Gray.}

In 1859 Gray gave a brief description of his genus Cluthraria as represented by $C$. rubrinodis. In 1870 he referred the genus to the family Mopselladæ and distinguished another species, $C$. acuta.

Gray's diagnosis of Clathraria is as follows:- "Coral shrub-like; branches cylindrical, ereet, tortnous, interoseulating, of nearly equal thickness ; branehlets, some free, blunt. Bark thin, granular. Cells small, immersed, nearly equally scattered on all sides of the branches; buds and branches from the swollen joints; joints elongate, white, longitudinally striated; internodes red. spongy."

Gray identified his C. mbrinodis with Kölliker's Mopsea bicolor ('Icones Histologieæ,' p. 142). Kölliker defined his genus Mopsea thus :- "Axis without nutritive canals. Spieules generally as in Melithea, but without the beautiful toliaceons clubs. Length of the elubs $0 \cdot 12-0.25 \mathrm{~mm}$. ; length of the larger polyp-spindles $0.18-0.34 \mathrm{~mm}$." Of $M$. lirolor he says:- "Soft joints red, hard joints white with green centre. ('oenenchyma "hite to sulphur-yellow, with uneven surface. Thickness of axis 4-7 mm."

In the "Challenger' Report (1899) Wright and Studer separate Clathraria from Mopsea, and give the following definition :- "Cylindrical manifoldly curving branches often anastomosing, and of uniform thickness throughout. The polyps are sunk in the conenchyma. The axis includes no nutritive canals. Spicules in cortex, broad and short foliaceous elubs."

In subsequent literature we find no further mention of Clathraria, though it is a very conspieuous and characteristic type. It is so unlike other Melitodids that its retention as a distinet genus seems desirable.

The specimens from the Red Sea are elearly referable to Clathraria and to the species $C$. mubrinodis and $C$. acuta. We are thas able to give the habitats of these two forms, which Gray was unable to do. The note in the "Challenger' Report that the spicules are "broad and short foliaceous elubs" must have crept in by some mistake.

The definitions which Gray gave of Clathraria and Mopsea hardly justifind him in his wide separation of the two genera, which he referred to different families. He makes no mention of the form of the spicules, and he says that the branches arise in both from the soft joints.

Kölliker's Mopsea is separated from his Melithoa by having no foliaceons chubs. His definition of Mopsea, so far as it goes, would cover both Mopsea and Clathraria.

In the "Challenger" Report the genus Mopsea is re-constructed, and if the Icfinition there given be considered more satisfactory than Kölliker's, then it is necessary to continue to keep Clathraria apart from Mopsea. It is noted, for instance, as a characteristic of Mopsea that the branches arise mostly from the internotes, whereas in Clathraria they arise mostly from the nodes. $[72]$ 
The spieules of Mopsea are deseribed as "finely-spined, unsymmetrical scales, slightly notehed at the edge; the spicules of Clathraria are spiny anit tubereulate cluls, warty double-elubs, and spindles with very minute waris." For these and other reasons we think that Clathraria may be usefully retained as a distinct genus.

\section{l'rovisional List of Red sea Alcyonarians.}

Those included in Mr. Crossland's collection are marked with an asterisk. The names in square brackets indicate the authorities for occurrence in the Red Sea. In other cases the authority for the species is also the autlority for its oecnrrence in the Red Sea.

\section{Oriler I. STOLONIFERA.}

* Clavuluria pulchru, Thomson \& Henderson.

Clavuluria strumosa, Ehrenberg.

rlarularia glauca (Savigny).

* Sympodium fulcum, Forskal [Klnnzinger] [Kiikenthal] $=$ (accordirg to Kïkentlal) Aleyonium fulvum (Forsk.).

siympodium caruleum, Ehrenherg. [Klunzinger] [Kiikenthal].

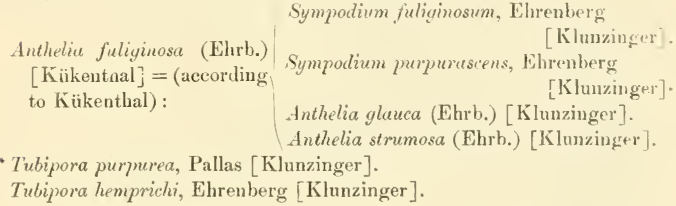

\section{Order II. ALCYONACEA.}

* Yenia umbellata, Savigny [Klunzinger] [Kükenthal].

* Nenia fuscescens, Elurenberg [Klunzinger] [Kïkenthal].

* Yenia camilea, Ehrenberg [Klunzinger].

Xenia blumi, Schenk [May].

* Aleyonium spharophorum, Ehrenberg [Klunzinger]. Alcyonium globuliferum, Klunzinger.

Alcyonium digitulatum, Klunzinger. Alcyonium pachyclados, Klunzinger. Alcyonium bracliyclados, Klunzinger. Alcyonium polydactylum, Dana [Klunzinger]. Alcyonium leptoclados [Klunzinger]. Alcyonium gyrosum, Klunzinger. 
Alcyonium panciforum, Ehrenberg.

Alcyonium polydactylum, Ehrenberg.

Alcyonium rubiformis, Ehrenberg.

Alcyonium aurum, Gray.

Alcyonium elegantissimum, May.

*Surcophytum glaucum, Quoy \& Gaimard.

Sarcophytum pulmo, Haeckel [Klunzinger].

Sarcophytum pauciflorum [Klunzinger].

Sarcophytum sarignyi, Klunzinger.

Surcophytum ehrenbergi, Marenzeller.

Sarcophytum trocheliophorum, Marenzeller.

- Sclerophytum gardineri, Pratt.

- Sclerophytum querciforme, Pratt.

* Sclerophytum densum (II hitelegge).

Lobophytum pauciflorum, Ehrenberg.

* Nephthya zanzibarensis, Thomson \& Henderson.

* Tephthya albida (Holm).

Teplthya chabrolii, Milne-Edwards \& Haime [Klunzinger].

-Lithophytum thyr'soides, (Kïkenthal) = Ammothea thyrsides, Ehrenberm

*Lithophytum arboreum, Forskàl [Klunzinger].

[Klunzinger].

"Lithophytum brassicum (May).

"Lithophytum crosslandi, n. sp.

"Lithophytum macrospiculutum, n. sp.

* Spongodes † hemprichi, Klunzinger [Klunzinger] [Kükenthal],

"Spongodes hartmeyeri, Kükenthal [Kükenthal].

* Spongodes suesiana, n, sp.

* Spongodes pharonis, n. sp.

Spongodes sacignyi, Ehrenberg (Klunzinger) [Kükenthal].

Spongodes ramulosa, Gray [Klunzinger].

Spongodes klunzingeri, Studer [Kükenthal].

Spongodes arborea, May [Kükenthal].

Spongodes mayi, Kükenthal.

Spongodes ehrenbergi, Kükenthal,

\section{Order III. PSEUDAXONIA.}

* Nelitodes coccinea (Ellis) $=$ Isis coccinea, Elli.

*Melitodes splendens, n. sp.

† According to Prof. Kuikenthal, who has revised this genus, the old namie spongendes ahould be changed to Dendronephthya. To us this appears neither necessary nor desirable. 
Mopsella emythracea, Gray [Klunzinger $=$ Mopsea erythrea $]$.

* Clathraria rubrinodis, Gray.

* Cluthrarice acuta, Gray.

siphonoyoryia miralilis, Klunzinger.

\section{Order IV. AXIFERA.}

Caligorgia verticillata.

Plexaure untipathes, Kölliker [Klunzinger].

Ple.eaura torta, Klunzinger.

Fermucella Alesuosa (Lamarck) [Klunzinger].

Juncella gemmacea, Kölliker [Gray] [Klunzinger].

Juncella hepatica. Klunzinger.

\section{EXPLAXATION OF TIE PLATES}

$$
\text { PLATF. } 5 .
$$

Fig, 1. Syonyorlex suesiana, n, sp. Nat. size.

2. Spongodes pharonis, n. sp. A small bundle of polyps. $\times 10$.

3. Spongodes pharonis, n. sp. Nat. size.

4. Lithophytum brassicum (Kükenthal). Nat. size.

5. Siarcophytum glaucum, Quoy \& Gaimard. Nat. size.

\section{Pi.tite 6}

Fig. 1. Melitodes coccinea (Ellis), $\times 12$.

2. Melitodes cuccinea (Ellis). Nat. size.

3. Clathraria rubrinodis, Gray. $\times 7$.

4. Clathraria mubinodis, Gray. Nat. size.

\section{Plate 7.}

Fig. 1. Melitudes splendens, n. sp. $\times 12$.

2. Melitodes splendens, n. sp. $\times 12$.

3. Clathraria acuta, Gray. Nat. size.

4. Clathraria acutu. Gray, $\times 7$.

\section{Piate 8.}

Fig. 1. Scleruphytum querciforme, Pratt. Nat. size.

2. Lithophytum macrospiculatum, n, sp. $\times 2$.

3. Lithophytum macrospiculatum, n. sp. A cluster of polyps. $\times 14$. 



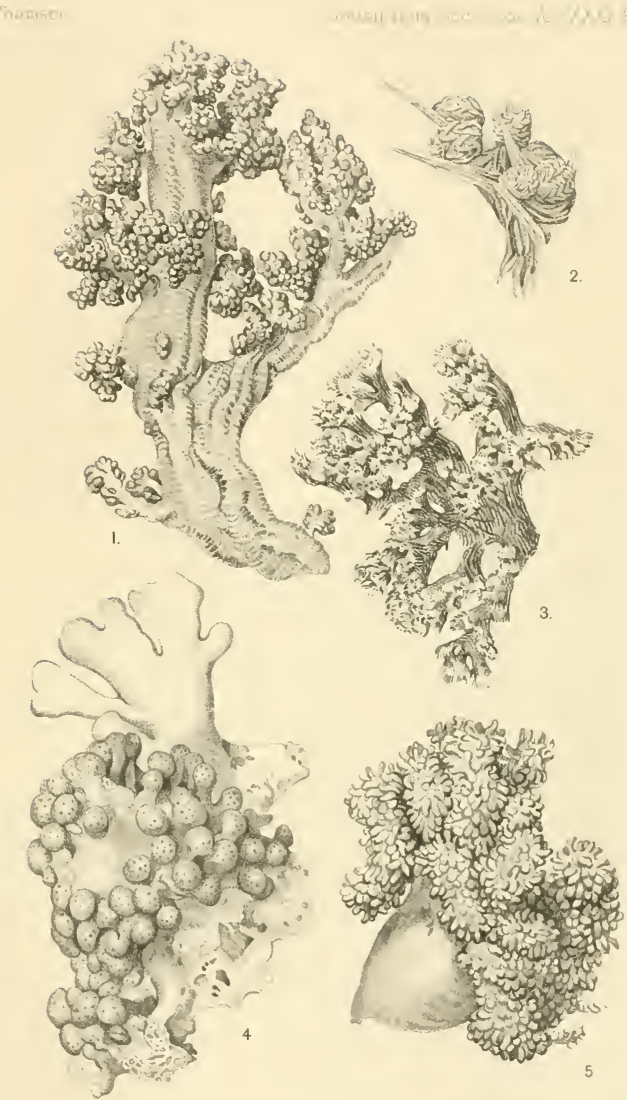





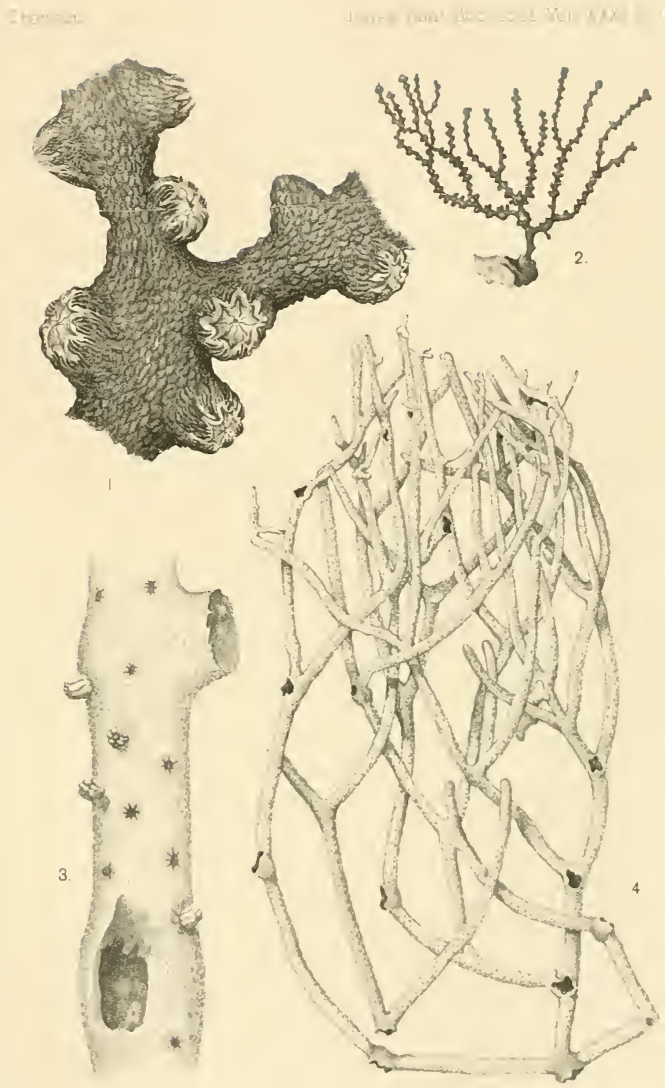





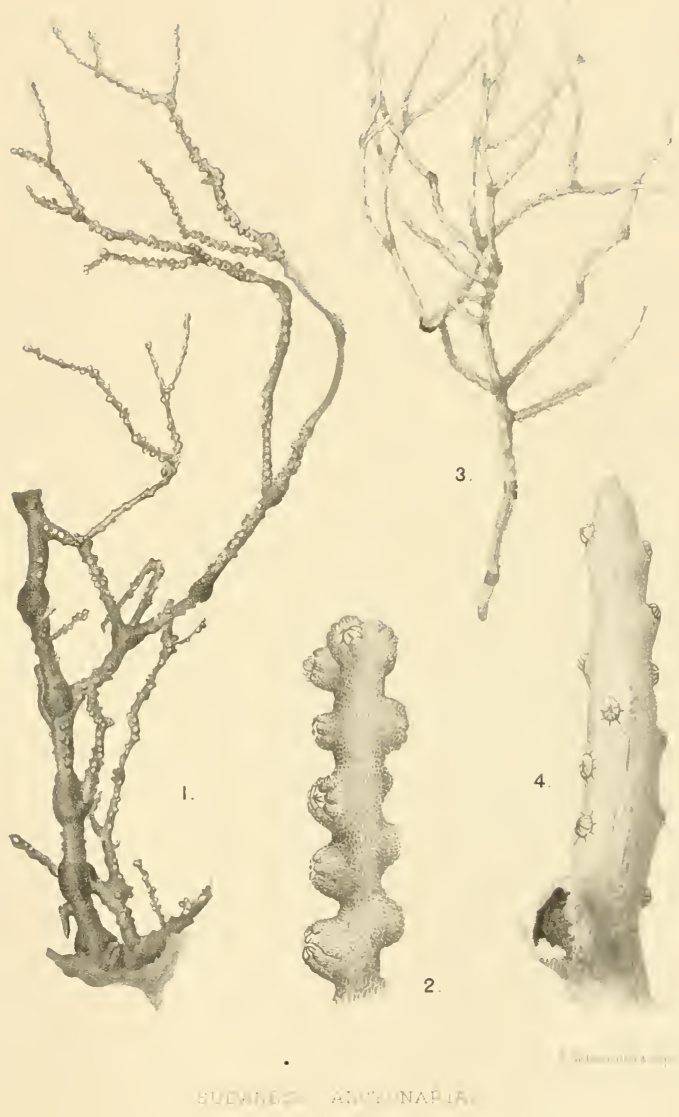





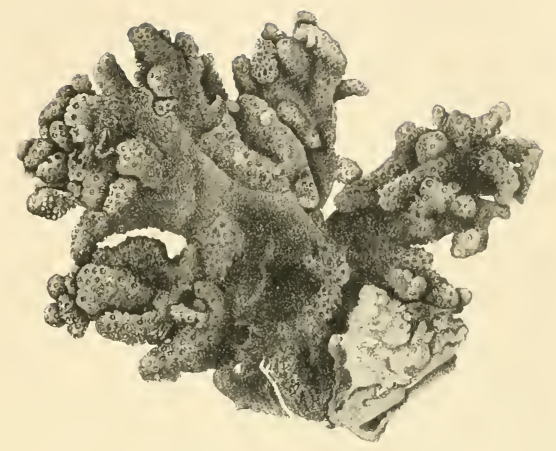

I.

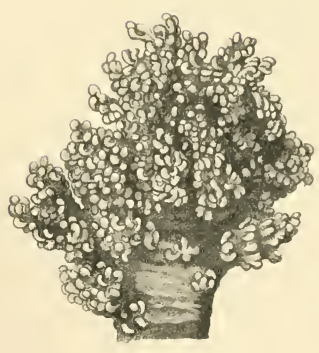

2.

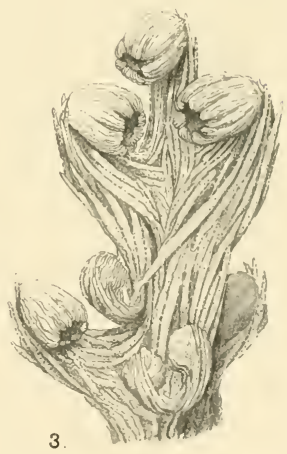

SUMASESE ALCYONAF: $A$ 

(Journ. R. Micr. Soc. 1908, pp. 675-81.)

\begin{abstract}
XX.-Note on a Remarkable Alyyonarian, Studeria* mirabilis g. et sp.n.
\end{abstract}

By Professor J. Arthur Thomson, M.A.

(Read November 18, 1908,)

Plate. XVI.

A COLleEtion of Aleyonarians made by the 'Investigator' in the Indian Ocean inchulel at specimen from the Andamans which is certainly one of the most remarkalle of the many interesting representatives of this sub-class that have heen discovered within recent years. It is a cup-like colony, with a large retractile polyparimm. The cup is $45 \mathrm{~mm}$. in leight by $55 \mathrm{~mm}$. in maximum diameter, and it is continued into a basal wisp (19 mm, in length). which, however, shows no attaching disk. The speeimen gave indication of having been imbedder in the mul up to al hout the maximum diameter of the cup.

General Structure. - The most striking peculiarity of this Alcyonarian is that the whole of the polyp-learing portion is retracted within the exceedingly suhstantial, densely spinose eup, the eircular month of which is about $30 \mathrm{~mm}$. in diameter, and shows the tips of numerons finger-like polyp-bearing lobes or branches. It seems quite likely that the mouth of the eup was capable of more complete closure, ancl, on the other liand, that the retracted polypariun was capable of considerable protrnsion.

A longitudinal median section of the single specimen slows a dome-shaped fleshy centre, or thalamus, from the margins and summit of which most of the nunernus tinger-like polyp-bearing lobes arise. Some of them, however, are attached to the inner wali of the cup at different levels. The central dome, it slould lxe noted, rises quite freely in the middle of the eup) its diameter is greater than half the maximum diameter of the cup. The arrangement of the polyp-hearing lobes may lie compraed to the distrilution of earpels and stamens in the flower of some of the liosacer. in which the former are disposed on a deme-shaped central thalamus, and the latter on several whorls on the inner wall of the " inlyxtube." Or, again, the central region of our speciment may lx. cim-

- I have named this type in honour of Profesor Th. Studer, of Bern, who has contributed so largely to our knowledge of Alcyonaria. 
pared to the disk of a Composite's eapitulum and the periphera parts to the ray-florets (plate XVI. fig. 1).

There are large longitudinal eanals in the central dome. separated by tough hyaline mesoglcea. Very strong musele-bands pass down their walls, and there are others in the wall of the cup' reaching almost to the margin. These longitudinal hands pass for a short distance into the wisp-like stalk and gradually disappear. Numerous well-defined transverse museles extend between the several longitudinal bands.

The Cup.-The cortical part of the wall of the cup, which is very definite and has a thickness of about $2 \mathrm{~mm}$., is extremely hard, consisting mainly of long spindles, readily visible to the naked eye (some over $5 \mathrm{~mm}$, in length), arranged for the most part in longitudinal interlacing rows. On the surface many of the spindles lie exposed throughout their whole length. Towards the base of the cup the spicules increase in size, and they attain their maximum dimensions-almost $1 \mathrm{~cm}$. in length -in the basal wisp. These are probably the largest Aleyonarian spicules as yet known.

The internal part of the wall of the eup, as distinguished from the hard cortex just described, is soft and muscular. It is about $9 \mathrm{~mm}$. in thickness where it joins the base of the dome, and narrows gradually to the margin of the eup.

The System of Canuls. - Each of the finger-like polyp-bearing lobes has a large eanal, with which the cavities of the polyps communicate. These branch canals pass into the dome or the wall of the cup, as the case may he, and uniting with others form the main longitulinal eanals. These are relatively large, especially at the hase of the cup and below the central dome, where they are about $2.5 \mathrm{~mm}$. in diameter. From this region of maximum size, they gradually taper into the wisp-like stalk. The walls of the canals bear the strong longitudinal muscle-bands, and there are very few spienles.

Polyp-bearing Lobes or Brunches.-Looking lown into the mouth of the cup, one sees the heads of between sixty and serenty polyp-bearing lobes or hranches, but the number visible will of course depend on the degree to which the dome is eontracted. Besides the branches on its summit, the central clome bears four whorls, and there are also four tiers on the wall of the cup. It should be noted, however, that the lobes do not all arise singly from the central dome, but may cohere for a distance of $2-6 \mathrm{~mm}$. at their bases. Some are united in pairs; in one ease seven were found to be eohering.

Polyps.-Each of the finger-like branches resembles a spikeinflorescence, and bears 150-200 close-set sessile polyps. These almost eover the surface, but without discernihle arrangement. It 
the sumnit there is a terminal polyp which is larger than the others. In many eases a branch his a length of $15 \mathrm{~mm}$. and a maximm diameter of $3 \mathrm{~mm}$., but in regard to these and other measurements of soft parts it nust he remembered that the whole colony has been mueh contracted by preservation in strong spirit (plate XVI. fig. 2.).

The polyps have ahmost globular ealyces or verrucie, with it diameter of about $1 \mathrm{mmm}$. The tentacles are in nost eases completely retracted, and the summit of the calyx shows a sharply lefined eircular aperture. The polyps with their calyees and precise circular aperture recall those of some of the Pennatulids, sueh as Virgularids. On the wall of the calyx there are eight triangular points, each eonsisting of two to three pairs of spienles arranged ch cherron, surmounting a collaret of several lierizontal rows. In most eases, lowever, the projecting spinlles of the cortical coenenchyma lide the base of the ealyx and may even intrule upon it. The anthocodia is very minnte ant is completely retractile within the glohular ealyx. The tentacles are short and thick, apparently withont spicules, and with about half a dozen pairs of pinnules.

Spicules.-Apart from a few irregular mimute forms found on the canal walls (and possibly extraneous) all the spienles are spindles. Many are huge, nost are lensely warted. The warts are often in close-set transverse rows, so that the spindle has a striated appearance. Many of the spimilles are curved in a sinuous fashion; not a few are irregularly forked (plate XVI. fig. 3).

The following measmements were taken of the spicules, length and brealth in millimetres :-

From the stalk: $\quad 9.5 \times \cdot 534: \quad 7 \times 51 ; 5.75 \times \cdot 476$.

From the cortex: $\quad 5.5 \times \cdot 476: 3 \cdot 5 \times .28 ; 1.75 \times \cdot 153$.

From the imer wall $5 \times \cdot 4 ; \quad 3 \times \cdot 2$; $2 \times \cdot 15$.

of the emp: $\quad 6 \times 51 ; 4.25 \times \cdot 4 ; 2 \cdot 75 \times \cdot 32$.

From the polyps: $1.45 \times 113 ; 1.02 \times .05 ; .45 \times \cdot 034$ : $.17 \times \cdot 018 ; \cdot 13 \times \cdot 017$.

I'osition of Studeriu. - If this trpe is to be referred to any of the recognised families of the Aleyonacen it must he to the Aleyoniitlet. In the retractility of the whole polyparium, as well as in the mole of branching, the disposition of the polyps and their armature, it is removed from the Nephthyids and Siphono. gorgids.

In certain respects, e.g. the distinct calyces into which the delicate upper parts of the polyps are retracted and the large longitulinal canals continued in part to the base of the colony, 
Studerin resembles Nidalia, but the Nidalia colony is unbranched, and there are many other differences apart from Studeria's retractile polvparium. In certain respects, e.g. in its huge spindles and in the finger-like lobes densely' covered with polyps, studeriu resembles a form like Sclerophytum polydactylum, but the polyps are quite different in the two, and there is not in Studeria ans lint of dimorphism. The non-retractile calyces, the mode of branching, the natme of the spiculation, and other features separate Studeriu from Alcyonim and several nearly related genera. So we might review all the genera of Alcyoniidie, but to little profit, for there is only one which can be thought of as having close aftinities with our new trpe. That one is the genus Paralcyonium, established by Milne-Edwards. Milne-Edwards gave the following diaguosis of Puruleyonium: "Polvparium of a coriaceous tissne towards the base and there forming a crlindrical tube with spiculose walls, into the interior of which all the upper and soft part of the polyparium, including the polyps themselves, can he completely retracted." *

In his original description of Paralcyonium, when he called it - Alcyonide, $†$ Milne-Edwards gave a number of interesting details. He distinguished a hrown firm "foot" fixed by its base, and a white, delicate, branched trunk with twigs ending in small polyps. The cavities of the polyps unite in forming longitudinal canals which are continued to the base, those which lie to the outside having their walls strengthened by numerous brown spindles. Ova are developed on lamelle in the lower part of the canals of the trunk and fall into the cavity, accumulating further down. On the polyps there are, accorling to Milne-Edwards, rows of " spicules cartilagineuses brunitres."

Wright and Studer gave the following definition of Purulcywiarm in the 'Challenger' lieport on Alcyonarians (1889):- "The colony presents two distinct portions: one, the basal portion, is dense, with firm walls; the other, the head, alone bears the polyps, and can be in frart withdrawn intu the basal part. The polyp-bearing portion is but feebly lobed." In his "Tersuch eines systemes der Aleyonaria" $\ddagger$ Studer had suggested affinity with Nidalia.

Our new type Studeria agrees with Paralcyonium (1) in having the polyp-luearing portion retractile into the basal portion, (2) in the disposition of the longitudinal canals, and (3) in having very large fusiform spicules. But there the resemblance stojs, and there can be no question as to the listinctiveness of the two very remarkable genera.

- Histoire Naturelle des Coralliaires, 1857, p, 129.

+ Ann. Sci. Nat, ser. 2, iv. (1835) pp. 323-33 (9 figs.).

+ Arch. Natur., liii. (1887). 
The most obvions difterenees between Studria and I'uralcyonium may he summed up in the following contrast :-

\section{Studeria miralielis.}

The polygs are crowded on unmerous finger - like branches, whicl cover a central dome, and also grow out from the inner walk of the eup.

The prolyjos have a dense armature of spicutes, forming : welldetiued calyx.

The walls of the cul' are very massive and hart.

The retractile polyparium is very sulstantial, including strong muscle-lands.

The larger spindles are very characteristic, being corered with warts in thick-set rows.

\section{Paratiyomium.}

'f'lic polsps are distant from one another, and are borne on the end of the twigs of at loosely-branched polyparium.

The polype have: mimnte spicules at the base of the tentacles. Jut there is no calyx.

The walls of the crlindrieal lower portion are not thiek, and the whole is readily compressible.

The retractile polyparimm is very delicate and translieent.

The spindles are much smaller, and much less warty.

It should be noted that studerin mirubilis is mueh larger than l'oralryonirm rlegens, wuch more massive, wich much larger and coarser spienles, and so on ; but we lave reason to believe that the massiveness of arehitecture is a specific, not a generic charaeter. We saw in Teptember in the Zoologieal Museum in IIamburg a number of un-named specimens of a form which we helieve to be elosely related to Studcria. By the courtesy of the director, Protessor Kiraepelin, aud of 1)r. Michaelsen, who has eharge of the section of the musemm containing Aleyonaria and the like, we were able to examine this form, and to compare it with the "Investigator' type. The Hamburg specimens, which were collected ofl Formusa ('Takan), agree with the 'I Iuvestigator' specimen in having a retractile polyparium, similar polyps, and the same type of lumge warty spindle, but they have not the strong massive enp, nor, so far as we lave seen, the same levelopment of eentral dome, or of digitiform lobes. We do not wish to pursue the comparison in the meantime, since L'rotessor Kükenthal has, we believe, mulertaken to describe the un-named Aleyouarians in the IIandmor Museum. We would, however, express our conelusion that hlir Hamburg sprecinens beloug, or are closely related, to the gemus Studeriu, which we have estahlished for the 'Investigator' type. [It must he alded that we exhihited, deseribed, and named the 'Investigater' specimen in Ausust 1907, at the Meeting of the International ('ongress of Zoologists at. Boston. Is we have hearl nothing regarding the manuseript which we depositerl, we have thought it vecessary to record the facts afresh.] 
M. Camille Viguier* las described and given beautiful tigures of a type which he calls Fuscicularia, and las proposed to include Puralcymizm along with it in at special family or sub-family, Fasciculariue. But it is not evirlent that Fescieuleria is really related to Puralcyonizm: it consists of groups united by stolons; the cavities of the polyus are continued, quite distinct from one inother, down the "basilar column ;" there is no common region except the base; the large polyps expand from the top of the basilar column, lut there is no branched or lobed polyparium; in fact, as the author says, there is no polyparium properly so-called. He makes the same remark, it is true, in regard to Parulcyonium, which, howerer, he had not seen. What at once marks Puralcyonium as distant from Fasciculariu, is the presence of a branched polyparium risiug from the top of a firmer eylindrical stalk, into which it can be retracted. Viguier speaks of the "incontestable resemblance " between his Fusciruluriu and the Parulcyonium of Milne-Edwark, but we are unable to share this view. The description of Fassiculurie suggests to us relationship with sympodium. rather than with Parrlcyonium.

A recent careful study $\dagger$ of abundant material of Fasciculuriu. and Paruleyonium by Sophie Motz-Kossowska and Louis Fage corroborates Viguier's view. In their interesting paper the authors point out that the two ty]es agree (1) in having a stolon connecting the colonies (but this is often almost suppressed in Paralcyonium); (2) in having a rigid basal portion into which the polyps can be retraeted (but in Fascicularia this is composed of the unfused gastric cavities of the polyps, whereas in Paralcyonium there has been much coalescence, and therefore far fewer longitudinal canals than polyps; moreover, Paralcyonium has a branching polyparium with secondary lolyps arising from primary polyps); (3) in having similar spicules-small, flat, opaque elliptical forms in a sub-tentacular collar and larger spindles in the basal portion (but the spindles are very much larger in Paralcyonium). The anthors point out that Parulcyonium passes through a Fascicularia stage, and in spite of the great cifference in the basilar portion and in the relations of the polyps to one another, they unite them in the family Fascicularidie, defined as foliows: "Colonies very poor in ccenenchyma, composed of several groups of polyps united by a stulon; polyps united at the base in a rigid column within which they ean be completely retracted." It is suggested that the fanily is connected by Fascicularia with the Clavularidæ, that there are some aftinities with Nidulia and

* Etudes sur les animanx inférienrs de la Baie d Alger. III Un nouveau type d'Anthozoaire (Fascicularia eduardsi). Arch. Zool. Expér. ser. 2, vi. (1888) pp. 351-73 (2 pls.). See also H. de Lacaze-Duthiers; Coralliaires du Golfe du Lion. Alcyomaires. Arch. Zool. Expér. ser. 3, viii. (1900) pp. 353462 (4 pls.).

† Contribution à l'étude de la famille des Fascicularidés. Arch. Zool. Expé . vii. (1907) pp. 423-13 (10 figs.). 
Nidaliopsis, and that the nearest related form is Organidus. The armature of the polyps in Nidalia, its unbrancherl hahit, and numy other features separate it fir from l'uralcyonimu, and fiersemia, in which, as Kükenthal laas shown, Irquovidus must be referTed, is equally remote.

We have not as yet been able to procure a specimen of Fitsicularia for examination, and we wond not therefore dognatimlly. exclude the possilnility that Fuscinuluric, Puruldyonium, anil Studcric form a series showing the progressive diflerentiation uf it rigid basilar portion into which the rest of the eolomy can be retracterl. The descriptions given ly Motz-Kossowska and Fage are very preeise, and theix discussion of the possible relationships is admiralule; what surprises us is that in spite of the diflerences which they indicate letween Fisciculuitu and Purulcyonium, they shoukl propose to include the $t w o$ in one family. Fron thein. deseriptions, as from Vignier's, it a]preats to us that Firsciculuria is more nearly related to S'ympordium than to Purelcymium; that it differs from I'erulcyonim ton markelly (in the structure of the basilar portion and in the relations of the polyps to this amel to one another) to allow of their heing incluterl in one family: and that neither is nearly related to Stuteriu.

Diegnosis of Studeriu. - A colony consisting of a strong densely spiculose cup, within which very mmerous finger-likic polypbearing lobes or branches are retracted; these arise at difforent levels from a strong museular central thalamns, and from the upere parts of the innex wall of the eup: eateh finger-like lobe is thickly. covered with polyps and ends in a polyp latrger than the rest; the cavities of the polyps communicate with a central canal in the digitiform lobe, and these central canals usite in a few large longitudinal cauals with few suicules in their walls; the polyjes have a distinet non-retractile alyx or verruca, covered with spiniles arranged in double rows; the spicules are all spindles, except it few minute irregular forms found (alone with sparse spindles) in the canal walls; many of the cortical spindles at tain huge limensions (over 9 mu.): many are sinuous and forked; almost all are very warty, and there is a characteristic artangement of the warts in transverse rows.

Our general eomelusion, which is based on a sinde specinen. of which we had to be careful, is that we have to do witl a very

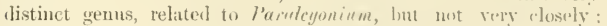
perhaps comnected thromgh forms like. Vidulin with other Ileyoniicle: but more probathly deserving, as l'onfessan lerrill sugransteil to $n$ s, the establishment if at new limily. 



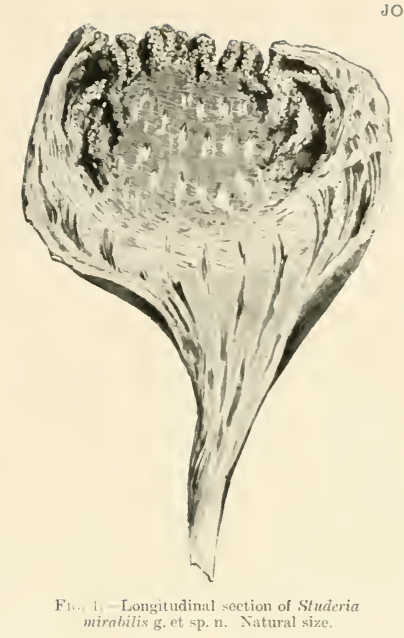

JOURN. R. MICR. SOC. 1908. PI. XVI.

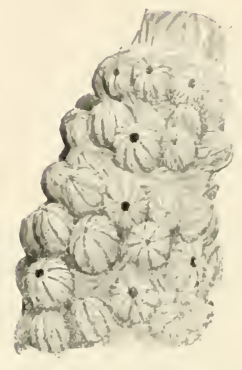

FIG. 2. The upper part of one of the digitiform polyphearing lohes or hranches of Studeria mirabilis g.et sp. n. It shows the terminal polyp mueh larger
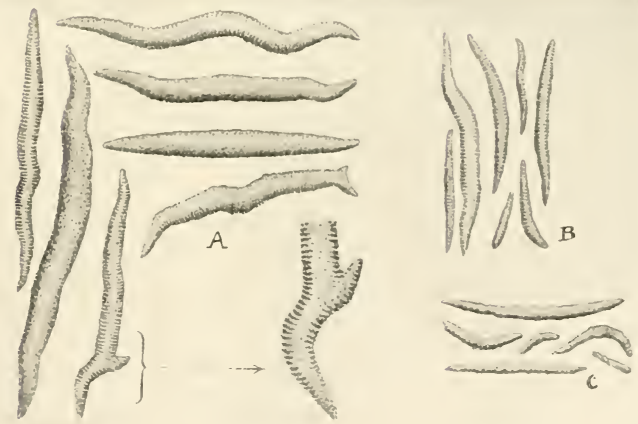

Frs. 3. Spicules of Studeria mirabilit.

A. From the stalk. P. From the internal wall of the cup. C. From a polyp. leatring lolwe. 



